\title{
A Theory of the Origin of Monocotyledons, founded on the Structure of their Seedlings.
}

BY

\author{
ETHEL SARGANT.
}

With Plates I-VII and ten Figures in the Text.

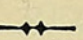

W

HEN some years ago I was working out the anatomical structure of the seedlings of Arum maculatum in collaboration with Mrs. Scott (36), we examined the seedlings of some other Aroids, and compared them with two species of Lilium seedlings. The anatomy of seedling Monocotyledons has received but little attention from botanists, and Dr. D. H. Scott suggested that I should pursue the subject by making a comparative study of those already collected by him from the material at Kew, and preserved for future investigation. I have to thank him not only for the start then made, but for his unfailing interest in the work as it developed, and for constant help in obtaining fresh supplies of material. The object proposed from the first was to throw light, if possible, on the relationship between Monocotyledons and Dicotyledons.

After some months of work in my own laboratory on the Kew material, I found it desirable to modify and extend the original scheme. The vascular system of the cotyledon, hypocotyl, and primary root appeared in the specimens I examined to be characteristic of the species. One of my

[Annals of Botany, Vol. XVII. No. LXV. January, 1903.] 


\section{Sargant.-Theory of the Origin of Monocotyledons}

early observations - the comparison of a seedling Anthurium with seedlings of Arum and Lilium-had suggested that this symmetry might furnish a new systematic character of some importance. The systematic value of any unproven character can be determined only by the careful comparative study of allied forms, and I therefore determined to confine my observations to a single family, and to work that out as fully as possible. With this object I began a careful study of seedlings belonging to the order Liliaceae.

The collection of material with all the help which Kew could give, and aided by the kindness of botanists in many countries, has been a laborious task. Seedlings have been raised from seed collected in my own garden, where I have cultivated a large collection of Liliaceous plants. I have also received seed from many sources, and I wish here to thank the Director of Kew Gardens and his Staff for their kindness in furnishing me with seedlings and seeds, and in naming the specimens which I have myself cultivated. My thanks are also due to those botanists who have sent me seeds, and in particular to Mr. Thomas Hanbury, of La Mortola, Professor S. Ikeno, of Tokyo, Mr. W. R. Guilfoyle, of Melbourne, Dr. J. H. Wilson, of St. Andrews, Mr. J. H. Maiden, of Sydney, Dr. K. Reiche, in Chili, Professor D. H. Campbell, and my neighbour, Mr. A. J. Crosfield. I have succeeded in preserving seedlings belonging to I 2.5 species from sixty genera within the Liliaceae, and over sixty species of other Monocotyledons. The collection of Liliaceous seedlings is fairly representative of northern genera : it is weak in species from the southern hemisphere, and I am particularly in want of more forms endemic to Australia and Chili.

The examination of this material is very far from complete. I have thoroughly worked out and made notes on some sixty species from the Liliaceae, and I have sections from about twenty-five species belonging to other monocotyledonous families. During a great part of the time employed in preparing sections and indexing them, as well as in drawing and registering the material, I have been admirably assisted 
founded on the Structure of their Seedlings. 3

by Miss E. N. Thomas. Most of the figures illustrating this paper have been drawn by Miss Agnes Robertson, who has also assisted me in many ways during the preparation of it.

\section{NATURE OF The Evidence.}

The examination of forms within the Liliaceae has convinced me that some vascular characters of the young seedling have real systematic value. At an age when the plant consists of cotyledon, hypocotyl, and primary root, with an embryonic plumule sheltered by the base of the cotyledon, the vascular system-in species which at that age have differentiated one-does often indicate the relationship of allied genera to each other.

The genera Anemarrhena, Asphodelus, and Asphodeline, for example, are placed together by all systematists, and the vascular structure of their seedlings shows an identical groundplan, though there are considerable modifications of the type in the two latter genera. So far the embryological evidence simply confirms the conclusions already drawn from the study of the mature characters. But when the unmistakable Anemarrhena type of symmetry is discovered in the seedlings of Galtonia and Albuca, we have an unexpected link between two groups of genera widely separated by systematists.

The instance just quoted is of exceptional interest for reasons already suggested in a preliminary notice, which appeared in the May number of the 'New Phytologist' (35). But it is only a fragment from a considerable body of evidence, which leads to the conclusion that embryological characters of the kind described can be shown to throw light on the inter-relationship of genera within the Liliaceae and allied orders.

Until the monograph I am preparing on the comparative anatomy of seedlings within the Liliaceae is completed, this evidence will not be published in detail. But I hope to give a sufficiently full sketch of it here to justify the publication 


\section{Sargant.-Theory of the Origin of Monocotyledons}

of a theory on the origin of Monocotyledons, founded primarily on the structure of their seedlings, and supported by the comparison of this structure with that of some Ranunculaceous genera in which the cotyledons are more or less completely united.

The argument requires that some weight should be given to the vascular system of the seedling as affording indications of its race-history. This postulate stated, I will briefly sketch the theory I have formed, and indicate the nature of the evidence on which it rests, before proceeding to give the evidence itself in greater detail than was possible in a preliminary notice.

The study of Liliaceous seedlings has led me to the conclusion that the various types of vascular symmetry found within the order can be linked with the type found in Anemarrhena, Albuca, and Galtonia, through more than one series of intermediate forms. I regard the Anemarrhena type as primitive, and as the starting-point from which most, if not all, the vascular types characteristic of Liliaceous seedlings have been historically derived.

The cotyledon of Anemarrhena contains two massive bundles which together form a tetrarch stele in the primary root. This structure originally suggested to me the possibility of a fusion of two seed-leaves in some remote ancestor to form the single cotyledon of Anemarrhena. According to this view each bundle in the hypocotyl represents the trace of one seed-leaf.

The seedlings of certain Dicotyledons possess seed-leaves which are partially united, sometimes by one margin only, but more often by both. In the latter case the united petioles form a tube, which is sometimes of considerable length. Petiolar tubes of this kind are found in several species of Anemone and Delphinium; in two species at least of Ranunculus and one of Trollius; in Aconitum Anthora and Eranthis hiemalis. The authorities for these statements will be found in Part II. Many other genera among the Ranunculaceae have cotyledons which are concrescent at the base. The petiolar tube 


\section{founded on the Structure of their Seedlings. 5}

of Podophyllum from the allied order Berberidaceae is very well developed.

Petiolar tubes are not confined to the Ranunculaceae and their near allies: they are found among the Oxalideae, Cucurbitaceae, Umbelliferae, Primulaceae, Polygonaceae, and probably careful search would discover them among seedlings of other families.

In every case investigated they are accompanied by a thickened or at least much shortened hypocotyl.

The anatomical structure of the petiolar tube and thickened hypocotyl of Eranthis, as described by M. Sterckx (38, p. 57), early attracted my attention because it recalled that of Anemarrhena. I have therefore studied it in detail.

The long petioles of Eranthis cotyledons are united into a narrow cylinder, which is hollow for the greater part of its length. The blades are distinct (P1. VI, Fig. I). Throughout the length of this tube the blade of each cotyledon is represented by a single massive trace. These traces are continued downwards through the tuberous hypocotyl into the primary root. The behaviour of the cotyledonary traces in the upper part of the tuber is precisely that of the cotyledonary traces in Anemarrhena where they enter the transitional region. This resemblance is maintained throughout the transition, until-near the base of the tuber-the four phloëm groups of Eranthis unite in pairs to form two groups, instead of remaining distinct. The four protoxylem groups, however, can be observed for some time after the xylem plate is formed (Pl. VII, Figs. I and 3): in the end the two which are opposite the phloëm groups disappear, leaving a diarch root-stele (P1. VII, Fig. 2).

The anatomical resemblance between the seedlings of Eranthis and those of Anemarrhena cannot be mistaken when the features just described are represented in diagrams. Its theoretical importance, however, has been denied by Mr. Tansley (40).

Three views are possible. The resemblance may be considered as accidental: as the result of inheritance from a 
common ancestor: or as the response of two unrelated forms to similar conditions.

The formation of a tetrarch root-stele from two cotyledonary traces is not common among Monocotyledons. It is, I believe, unknown among Dicotyledons. The indications of such a tetrarch formation in Eranthis are to my mind very clear-I cannot dismiss them as accidental. This consideration leads me to believe in a real genetic connexion between Eranthis and Anemarrhena: that they are descended from a common ancestor with two distinct seed-leaves, each represented by a single trace in the hypocotyl. If we suppose that this is in its turn descended from a form in which two traces enter the hypocotyl from each cotyledon, the tetrarch root will no longer present any difficulty.

But even if there be no historical connexion between these genera, the structure of Evanthis may nevertheless illustrate the double origin of the Anemarrhena cotyledon. For without the analogy of Eranthis the assumption that each trace in the cotyledon of Anemarrhena represented a distinct seedleaf was groundless. Not only was direct evidence of such a double origin absent, but there was nothing to show that the union of two cotyledons, if it did take place, would actually give rise to such a type of vascular symmetry. To settle the matter by experiment was out of the question. But in Eranthis the cotyledons are partially united, and the vascular symmetry bears a very close resemblance to that of Anemarrhena. If there is no common stock from which both forms are derived, Eranthis may be considered as a genus in which Nature has partly repeated the experiment which she concluded in Anemarrhena, and with a similar result as regards the vascular system.

This is the line of argument on which my theory is based, and it remains now to give a fairly full abstract of the evidence which supports it. I propose to do so under two heads.

In the first place I shall describe the chief types of vascular symmetry which have so far been found within the Liliaceae, 
and the intermediate forms which have led me to derive them from the Anemarrhena type. These facts will, I hope, go far to justify the preliminary assumption that the vascular symmetry of the seedling affords a new systematic character, which-at least among the Liliaceae-is often of value in indicating the historical connexion between genera. While on this subject I shall also describe more briefly some monocotyledonous seedlings outside the Liliaceae, and in particular those whose structure connects the group to which they belong with that family.

In the second place, I intend to describe in detail the firstyear seedling of Eranthis hiemalis, comparing its vascular structure with that of Nigella damascena, already well known through the descriptions of MM. Gérard, Dangeard, and Sterckx. From the other Ranunculaceous species which possess cotyledonary tubes, I have examined and shall shortly describe Anemone coronaria and a species of Delphinium, and for comparison with these exceptional forms I have chosen four species with distinct cotyledons from the same family. In conclusion, the seedling of Ranunculus Ficaria will be fully described as a type in which the cotyledons are partly united by one margin only.

These two chapters will complete the account of the evidence on which my theory is based. This evidence is obviously incomplete. The theory itself cannot be considered as proved in any sense. It is brought forward as a working hypothesis which I have found in practice to be suggestive and illuminating. But a theory of the origin of the monocotyledonous cotyledon is in fact a theory of the origin of Monocotyledons themselves, and therefore to the two chapters which contain my own observations on the comparative anatomy of seedlings I shall add a third dealing with the theoretical aspect of the subject. In this I shall try to show that the same habit of life which leads to the partial union of some dicotyledonous seed-leaves may in the past have produced one or more distinct races with seed-leaves so completely united that they appear to form a single member. 
Whether the Monocotyledons as we know them now are descended from one such race, or have branched off in this way at several distinct periods and from different dicotyledonous stocks, must remain an open question for the present.

\section{OBSERVATIONS ON THE ANATOMY OF SEEDLINGS.}

\section{PART I. MONOCOTYLEDONS.}

\section{A. Liliaceae.}

The species cut and completely examined from this family amount to sixty, representing thirty-five genera. Of these, forty-five species, representing twenty-six genera, belong to the four central tribes: Asphodeleae, Allieae, Scilleae, Tulipeae.

Three complete series of sections from the transitional regions of three seedlings, differing somewhat in age, have been examined and kept for reference before the final notes on any species were compiled. Where the first seedlings cut have shown considerable diversity of structure, more specimens have been examined: in some cases details of seven, eight, or nine seedlings are included in the notes.

The series of sections have always been followed from the cotyledon downwards through the hypocotyl into the primary root. This I have found in practice more convenient than working upwards from root to stem. But the lignification of the traces is usually at its maximum about the middle of the transitional region, and in general proceeds upwards and downwards from that level.

Many observers have remarked that the limits of the hypocotyl differ according as they are defined by external or internal characters. In this paper I am concerned chiefly with the internal anatomy of the seedling, and I therefore define the upper limit of the hypocotyl by the insertion of the plumular traces on those of the cotyledon, and its lower limit by the formation of a stele with complete rootcharacters. 


\section{founded on the Structure of their Seedlings. 9}

This region is commonly very short in Monocotyledons. In bulbous or tuberous species it rarely exceeds $.5 \mathrm{~mm}$., and in many cases can hardly be said to exist except by a sort of legal fiction. Even in herbaceous and arborescent species the hypocotyl as defined above rarely attains a length of $3 \mathrm{~mm}$.

The symmetry of the root-stele is sometimes determined by the cotyledonary traces only: sometimes by cotyledonary and plumular traces together : and in a few exceptional cases it appears to depend on the plumular traces only (Aloineae, Bulbine, Tamus). The systematic indications are most constant in the first case : that is, when the cotyledonary traces only are continued into the primary root, and its symmetry is unaffected by the insertion of the plumular traces. I have learnt to look on this as the primitive arrangement. It is found in species which are somewhat tardy in developing the plumular leaves. The root-stele in such species is fully differentiated, while the plumular traces are still embryonic.

The early or late development of the plumule is of course a question chiefly of the habit of the species, and this is determined by the external conditions to which it is exposed. The seedlings of climbers and arborescent species, for example, commonly develop the plumule early, and the primary root of such species is comparatively long-lived. It must therefore be polyarch in order to attain sufficient girth, and as a rule in plants of this habit many plumular traces are continued downwards into the root-stele, side by side with the cotyledonary traces.

In such cases I have found the features of the transition to vary considerably, even among individuals of the same species. The primitive characters are swamped among those which are more or less dependent on external conditions, and these are necessarily variable.

\section{Tribe Scilleae.}

Seventeen species, representing ten genera, have been examined from this tribe.

Albuca Nelsoni. The seedling is slender, and attains some 
size before the position of the plumule is defined externally as a swelling near the base of the cotyledon $\left(A_{5}\right.$ in Pl. I, Fig. I). The cylindrical cotyledon is green, and acts as the first assimilating organ. Its apex carries the seed out of the ground, and remains within it until the supply of food in the endosperm is exhausted. The primary root is still unbranched in $A_{5}$, and no other has appeared. The upper limit of the root is defined externally by a sudden increase in diameter. Later on, when the base of the cotyledon has expanded into a sheath which envelops the growing plumule $\left(B_{1}\right.$ in Fig. I, Pl. I), this abrupt increase in girth is not so clear, but there is a distinct constriction separating the base of the bulb from the top of the root.

The two seedlings figured $\left(A_{5}\right.$ and $\left.B_{1}\right)$ have been dissected. In each there are two massive bundles running the whole length of the cotyledon. Their phloëm groups are very well developed, as is generally the case when the cotyledon serves as a sucking organ for some time after germination. The cotyledonary sheath of $\mathrm{A}_{5}$ possesses in addition five lateral bundles, which are formed near the top of the sheath by the branching of the two main bundles. Near the base of the sheath they join the plumular traces above the level at which these are inserted on the main cotyledonary traces. The far larger sheath of the older seedling $B_{1}$ possesses no less than twelve of these minor bundles: all given off by branching from the main bundles, and all ultimately merged in the plumular stele, or ending blindly before the transition from root to stem begins.

The presence of lateral bundles in the cotyledonary sheath, though not confined to the Scilleae, is very characteristic of the tribe. They do not always arise by the branching of others, but are sometimes formed independently, and disappear without joining other traces. When this is the case they probably serve merely to stiffen the sheath.

The seedling $A_{3}$, from which the sections drawn in Figs. 2-4 were cut, is younger than $A_{5}$, and there are only two slender lateral strands in the cotyledonary sheath in addition to the 
two massive bundles on which the transition depends (Fig. 2). These behave precisely as the corresponding bundles of Anemarrhena (Diagram VI). The phloëm group of each divides into two parts, and the protoxylem group branches in three directions $\left(p x_{1}, p x_{2}, p x_{3}\right.$ on one side, and $p x_{4}, p x_{2}^{\prime}, p x_{3}^{\prime}$ on the other in Fig. 3, Pl. I). The four phloëm groups thus formed continue downwards into the primary root, but the six protoxylem groups of Fig. 3 are reduced to four by the fusion of $p x_{2}$ with $p x_{2}^{\prime}$ and $p x_{3}$ with $p x^{\prime}{ }_{3}$.

So far the transition follows the Anemarrhena type exactly. But in Albuca the permanent stele of the primary root is not always tetrarch. The protoxylem group $p x_{3}+p x^{\prime}{ }_{3}$ in Fig. 4 is less prominent than the other three. A little lower down it has disappeared altogether; the phloëm groups on either side of it have united, and the root-stele is triarch. In the seedling $A_{5}$ a similar suppression occurs. The primitive tetrarch structure is barely indicated before two of the protoxylem groups-those corresponding to $p x_{2}+p x^{\prime}{ }_{2}$ and $p x_{3}+p x^{\prime}{ }_{3}$ in Fig. 3-become less prominent, and for a considerable distance it appears as if the root would ultimately become diarch. In the end, however, one of the menaced protoxylem groups recovers itself, and the root is triarch as in $A_{3}$. In both seedlings the lateral protoxylem group which persists is that on the side from which the plumular traces have entered the stele.

If the irregularity just described could be thought to cast any doubt on the homology of the transition in Albuca with that of Anemarrhena, that doubt would be removed by the series from $B_{1}$, the oldest seedling cut. In this transition the two cotyledonary traces give rise to a tetrarch root. The process is the same as in Anemarrhena, step for step, and when once formed the root continues tetrarch to the end of the series, a distance of $.75 \mathrm{~mm}$. from its first formation.

The vascular structure of the seedling in Albuca Nelsoni is doubly interesting. In the first place it follows the Anemarrhena type of transition so closely as to demonstrate the existence of this type within the Scilleae. In the second, 


\section{Sargant.-Theory of the Origin of Monocotyledons}

its variations from the Anemarrhena structure are hardly less important.

The existence of lateral bundles in the cotyledonary sheath is, as I have said, characteristic of this tribe. In Albuca we see a number of such lateral bundles present side by side with the main bundles, but obviously derived from them, and exercising no influence on the symmetry of the hypocotyledonary stele. In other genera such lateral bundles assume a greater importance, and to some extent replace the main bundles, but these variants on the typical structure are linked to Albuca by a series of intermediate forms, some of which I shall describe in detail (Hyacinthus romanus, Muscari atlanticum, $M$. armenaicum). The comparative study of these species and others, joined with that of a series among the Asphodeleae, leaves no doubt that the lateral bundles of the cotyledon are structures of more recent date than the main bundles.

Again, the formation of a triarch root in some individuals of this species by the suppression of the median protoxylem group in one of the main bundles $\left(A_{3}, A_{5}\right)$, and the temporary suppression of the corresponding group in $A_{5}$, indicates a tendency in these median protoxylem groups to disappear. Moreover, the fact that the median group which survives is that next to the plumular traces shows the influence that these-when developed early-may exercise on the symmetry of the stele.

Galtonia candicans and Dipcadi serotimum are alike in possessing several lateral bundles in the cotyledonary sheath besides the two main bundles which run the whole length of the cotyledon. In both genera two or more of these lateral bundles, together with the plumular traces inserted on them, enter the hypocotyledonary stele, and exercise a capricious influence on the symmetry of the root-stele. Individuals within the same species differ profoundly from each other in the details of transition: triarch, tetrarch, or pentarch steles are found in the primary root of Galtonia candicans; triarch or tetrarch steles in that of Dipcadi serotimum. The behaviour 
founded on the Structure of their Seedlings. I 3

of the two main bundles themselves is affected by these irregularities, but in some specimens of both species they follow the Anemarrhena type exactly, and in almost all they clearly begin on that plan, though it is not pursued throughout the transition.

Species in which the transition presents such irregularities cannot be fully described here: they are mentioned because in individuals of both species a modification of the Anemarrhena transition is found which reappears elsewhere.

In this variant the phloëm of each main bundle divides into three groups, of which the median one remains in situ
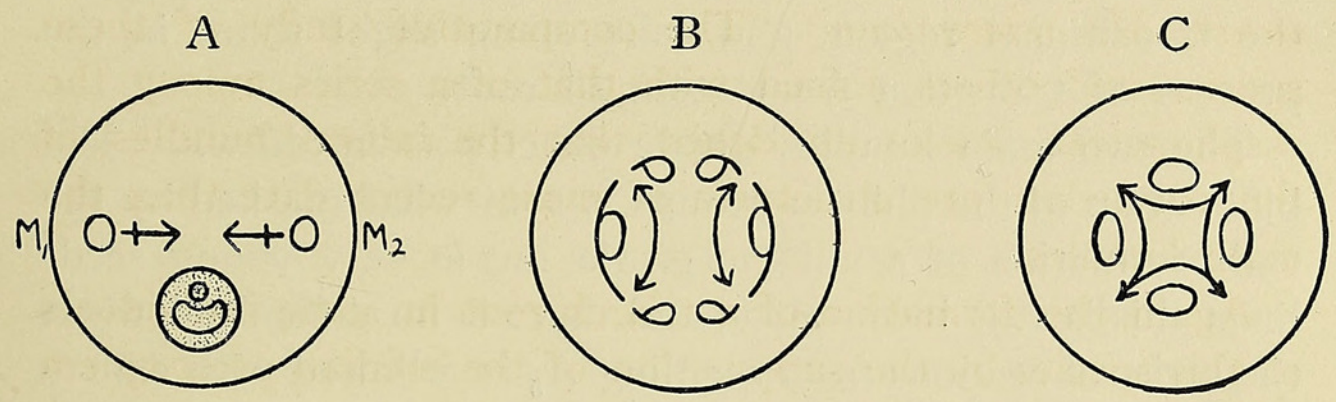

DiAgRAM I.

and is continued downwards unchanged. The right-hand branch unites with the adjacent branch from the other bundle, and a similar fusion occurs on the opposite side of the stele. The protoxylem of each main bundle divides into two groups, each of which becomes external as it takes up its position on one side or other of the median phloëm group. The root is of course tetrarch (Diagram I).

The examination of the transitional region in six seedlings of Galtonia candicans has convinced me that the type of transition just described is derived from type 4 (Anemarrhena). It stands in precisely the same relation to that type as Van Tieghem's type 3 to his type $\mathbf{I}^{1}$, and for convenience I shall refer to it as type 5 .

The genera Hyacinthus and Muscari include a number

1 Traité de Botanique, ed. ii, I89I, vol. i, p. 782. 


\section{4 Sargant. - Theory of the Origin of Monocotyledons}

of forms in which the lateral bundles of the cotyledon take a perfectly regular share in the formation of the root-stele.

The species Hyacinthus romanus, Muscari atlanticum, $M$. armenaicum and $M$. neglectum, for example, form a series in which the lateral traces become more and more important until they supply a full half of the root-stele.

Hyacinthus romanus. In the seedling figured $\left(\mathrm{A}_{5}, \mathrm{Pl}\right.$. I, Fig. 5) there are four slender lateral strands in the cotyledonary sheath at an age when even the midrib is not indicated in the first leaf (Pl. I, Fig. 6). These four strands unite in pairs : the two traces thus formed enter the stele just above the transitional region, and take some slight share in the process of transition from stem to root.

The two main bundles divide exactly as in Albuca. The bifurcation of the phloëm groups is somewhat masked by the early formation of a phloëm girdle, but in very young seedlings this is still incomplete, and there is no difficulty-when the series of sections from seedling $A_{5}$ is followed with carein identifying the phloëm group to the top or north of the section figured in Pl. I, Fig. 7 with half the phloëm of $\mathrm{M}_{2}$. The rest has united with the adjacent phloëm group of the lateral bundle $1_{2}$ to form the right-hand or eastern group. The whole of the phloëm belonging to $M_{1}$ has joined that of $l_{1}$, and the united groups are now represented by the phloëm crescent on the left hand or south-western side of the stele (Pl. I, Fig. 7). The xylem is in two masses, between which extends a slender crescent of protoxylem elements. This is formed by the xylem of the two lateral bundles $l_{1}$ and $1_{2}$, together with protoxylem elements from the two main bundles $\mathrm{M}_{1}$ and $\mathrm{M}_{2}$. These will together form the protoxylem group $p x_{3}+p x^{\prime}$ of figures 8 and 9 on the same plate. The corresponding group to the north of the stele in Fig. 8 is formed by the union of protoxylem branches from the two xylem masses shown in Fig. 7 (Pl. I, Fig. $\left.8, p x_{2}+p x_{2}^{\prime}\right)$. The median protoxylem group of $\mathrm{M}_{2}\left(p x_{4}\right.$ in Fig. 8 ) is also well developed, but that of $\mathrm{M}_{1}$ can hardly be made out. Its 
position is indicated by a break in the centre of the phloëm crescent (cf. Figs. 7 and 8). Later on the development of the protoxylem ray $p x_{1}$ (Pl. I, Fig. 9) completes the formation of a tetrarch root.

Every step in this process can be followed in the series of sections from which Figs. 6-9 were drawn, and it is clear that the whole symmetry of the root-stele depends on the two main bundles $\mathrm{M}_{1}, \mathrm{M}_{2}$, and is derived from them as in Albuca. The two lateral bundles $1_{1}, l_{2}$ simply contribute a few xylem elements to the group $p x_{3}+p x_{3}{ }^{\prime}$, and some phloëm elements to the two lower phloëm groups. In these points the two other seedlings examined agree with $A_{5}$.

Muscari atlanticum. The apex of the cylindrical cotyledon (Pl. II, Fig. I) contains two bundles. A little lower down each of these gives off a branch. The four bundles thus formed run downwards through the whole length of the cotyledon into the sheath. No additional bundles have been seen in the sheath of the oldest seedling examined. Throughout their course the two original bundles $\left(\mathrm{M}_{1}, \mathrm{M}_{2}\right.$, in Fig. 2, Pl. II) are larger than those derived from them.

In seedling $A_{4}$, from which Figs. I-3 were drawn, the transition takes place very suddenly, but with diagrammatic clearness. In Fig. 2, Pl. II, the four traces are seen to approach each other. As they do so the phloëm group of each branches to right and left, and from the eight branches five definitive phloëm groups are formed by the fusion of three adjacent pairs. This is very clearly seen in the single section which separates those drawn in Figs. 2 and 3 on Plate II. The lowest phloëm group in Fig. 3 is formed by the fusion of branches from $l_{1}$ and $l_{2}$. That on the left hand of the lowest group is derived from the lower branch of $\mathrm{M}_{1}$ fusing with the upper one of $\mathrm{l}_{1}$. The phloëm group on the right of the lowest is formed from the lower branch of $\mathrm{M}_{2}$ and the upper one of $1_{2}$. The two upper phloëm groups represent the upper branches of $\mathrm{M}_{1}$ and $\mathrm{M}_{2}$ respectively.

The xylem groups of $M_{1}$ and $M_{2}$ each branch in three 


\section{I6 Sargant.-Theory of the Origin of Monocotyledons}

directions. The two upper branches ( $p x_{2}$ and $p x_{2}^{\prime}$ in Fig. 3) unite, while the median branches $\left(p x_{1}\right.$ and $\left.p x_{4}\right)$ maintain their identity. The lower branches $\left(p x_{3}\right.$ and $\left.p x^{\prime}{ }_{3}\right)$ are separated by the lowest phloëm group, which is that derived from the two lateral branches. The xylem of $l_{1}$ fuses with the branch $p x_{3}$, and the xylem of $1_{2}$ with $p x^{\prime}{ }_{3}$. These changes when accomplished produce a pentarch root-stele.

Of the two other seedlings cut, one agrees in every point with $A_{4}$. The other begins in the same way, but one of the median branches of protoxylem is suppressed after it has been formed, which leads to the asymmetrical formation of a tetrarch root. This is clearly anomalous.

The lateral bundles of Muscari atlanticum play a more important part in the process of transition than they do in Hyacinthus romanus. They add a phloëm group to the stele, besides contributing elements to two others and to two protoxylem groups. The division of the two main bundles takes place exactly as in Albuca.

Muscari armenaicum. The cotyledon contains four bundles almost throughout its length. Two of these are more massive than the others. Each of the two slighter bundles gives off a branch in the upper part of the sheath. Below this level we find two main bundles and four lateral ones in the sheath. But the two supplementary bundles reunite at the first node with the bundles from which they arose, and the transition from stem to root takes place with four traces only in the stele.

Sections from the transitional region of two of the three seedlings cut are drawn in Figs. 5, 6, 7, and 8. The third seedling, $A_{4}$, is younger than the others, and the lateral traces are poorly developed. The process of transition, however, is clear, and it is precisely that just described for $M$. atlanticum. The transition in seedling $A_{3}$ differs from this, and that of seedling $A_{5}$ is unlike either.

In seedling $A_{3}$ one of the two main bundles $\left(M_{1}\right)$ behaves in the characteristic way. Its xylem branches in three directions : its phloëm bifurcates. But in the second main bundle $\left(\mathrm{M}_{2}\right)$ 
the median protoxylem branch, if formed at all, is early suppressed, and the phloëm group remains single. In the anomalous seedling of $M$. atlanticum a similar suppression led to the formation of a tetrarch root. The seedling with which we are dealing, however $\left(\mathrm{A}_{3}\right.$ of $M$. armenaicum), forms a pentarch root owing to the increased activity of the lateral bundles. Their phloëm groups remain undivided, and are continued directly downwards as the two lower groups of the root-stele (P1. II, Fig. 6). Each xylem group, on the other hand, branches to right and left ; the two adjacent branches unite to form the lowest protoxylem group of the root, and

A

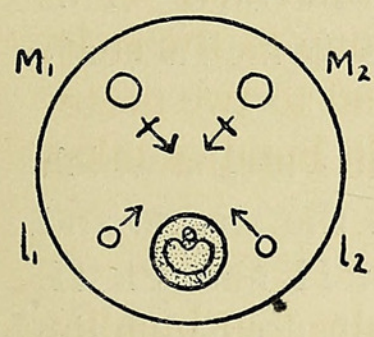

$\mathrm{B}$

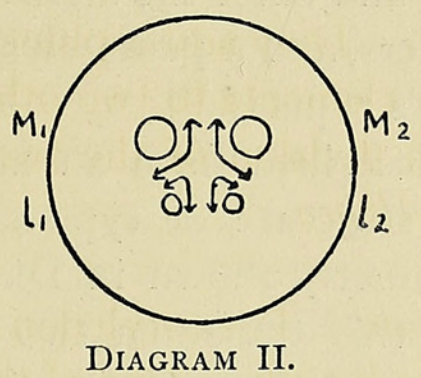

C

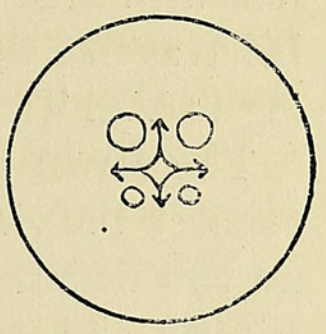

the upper xylem branches unite with the adjacent branches from the main bundles.

Thus the lateral traces provide two phloëm groups, one protoxylem group, and contribute elements to two other protoxylem groups of the pentarch root-stele.

Finally, in seedling $A_{5}$ we find the lateral bundles contributing a full half of the tetrarch root-stele (Diagram II). The median protoxylem branches of both main bundles are suppressed. In $\mathrm{M}_{1}$ this median ray is indicated during the earlier stages of the transition: in $\mathrm{M}_{2}$ it never appears. Thus both main phloëm groups are continued downwards into the root-stele unchanged. So are the two phloëm groups of the lateral bundles, which are, however, smaller than the main groups (P1. II, Fig. 9). The xylem of main and lateral traces alike branches to right and left, adjacent branches fusing in 


\section{8 Sargant.-Theory of the Origin of Monocotyledons}

pairs. Thus the tetrarch root is formed according to Van Tieghem's type $\mathrm{I}$, and the distinction between main and lateral bundles is indicated only by the slight want of symmetry due to the smaller size of the lateral traces (P1. II, Fig. 9).

Muscari neglectum. The sheath of the cotyledon contains four or more lateral bundles in addition to the two main bundles. In two of the seedlings cut $\left(A_{5}\right.$ and $\left.A_{7}\right)$ all the lateral bundles except two disappear before the transition begins: inserting themselves for the most part on the two which remain. The transition to a tetrarch root then proceeds regularly as in Diagram II.

In seedling $A_{2}$, however, two of the supernumerary bundles fuse with each other and enter the stele as a fifth trace. This behaves like the others, and a pentarch stele is formed according to Van Tieghem's type $\mathrm{I}$.

The forms just described form an unbroken series which connect the Albuca structure, or type 4, with the simple and no less definite symmetry shown in Diagram II and Pl. II, Figs. 8 and 9. In this transition two lateral traces of the cotyledon take an equal share in forming the root-stele with the two main traces. All four traces behave alike, following Van Tieghem's type I.

The same symmetry in essentials is characteristic of the transition in Eucomis nana, Jacq., but with one interesting variation.

In Fig. 5 on Pl. II the two main bundles $\mathrm{M}_{1}$ and $\mathrm{M}_{2}$ are seen to be united by a common protoxylem group, which has already begun to turn outwards. The lateral bundles are still quite distinct from the main bundles and from each other. In this case the fusion of the two main bundles has only just occurred : they were distinct $.02 \mathrm{~mm}$. above the section drawn in the figure. But in Eucomis nana the main bundles are united throughout the cotyledonary sheath. In its upper part they resemble a single massive bundle; lower down this opens out into a double bundle with distinct phloëm and xylem but a common protoxylem group. Just above the 
transition the two bundles resemble those in the cotyledon of Fritillaria imperialis (Pl. III, Fig. 2), but are rather nearer together, the protoxylem groups fused. As in Muscari armenaicum $\mathrm{A}_{3}$, and in Fritillaria also, the protoxylem is already on the way to become external, though the transition proper has not begun.

During the transition in Eucomis nana the double bundle contributes an exact half to the tetrarch root-stele. Its two phloëm groups are continued directly downwards, and the protoxylem, besides forming the ray separating these phloëm groups, sends out branches to right and left, which unite with branches from the two lateral traces entering the stele.

This is in effect the transition shown in Diagram II. In that case, however, the lateral traces were throughout smaller than the main traces, and the tetrarch root-stele was, when first formed, one-sided from this cause (Fig. 9, Pl. II). In Eucomis nana the converse is the case. The lateral traceson which are inserted not only the supernumerary traces of the sheath but also the plumular traces-are more massive than the reduced main bundles, and the tetrarch stele is at first less well-developed on the side from which the main traces enter it.

Throughout this description of the transition in Eucomis nana I have assumed that the double bundle of the cotyledon represents the two main bundles of Muscari. This assumption is justified, I think, not only by the behaviour of the traces in the hypocotyl, but also by their orientation within the cotyledonary sheath. The double bundle is placed in the thickest part of the sheath, exactly opposite the first leaf, and this is also the position of the two main bundles in the sheath of Muscari. Compare the position of $\mathrm{M}_{1}$ and $\mathrm{M}_{2}$ in Pl. I, Fig. 6, Hyacinthus romanus. It is by no means uncommon to find two separate bundles replaced by a double bundle in allied genera. For example, in Fritillaria (Pl. III, Fig. 2) the bundles of the cotyledonary sheath are separate: in Lilium they are joined as in Eucomis. In Bloomeria they are separate: in Allium joined. 
Before describing hypocotyls, in which the main cotyledonary traces play a subordinate part, I must mention an interesting variant on the form of transition just described (Muscari armenaicum $\mathrm{A}_{5}$, and others), which is found in Scilla sibirica.

Two main traces and two lateral ones enter the hypocotyl from the cotyledon. The four xylem strands are continued straight downwards into the root, and the protoxylem of each becomes external during the passage. Each of the four phloëm groups divides into two, and the half of each bundle unites with the half of the bundle lying next to it

A

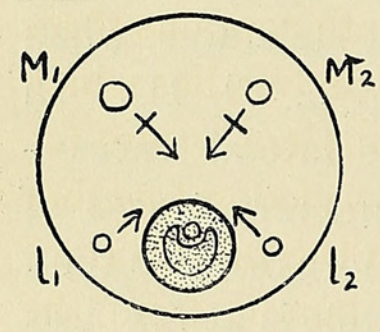

$\mathrm{B}$

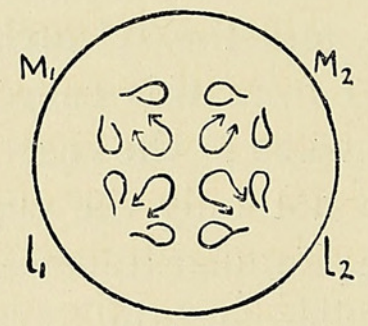

DIAGRAM III.

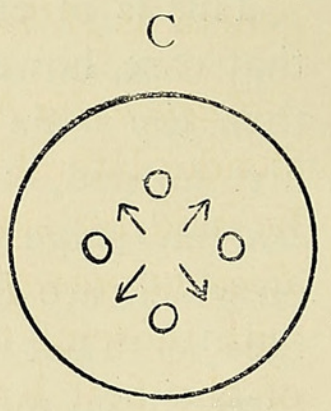

(B, Diagram III). In short, the four cotyledonary traces become a tetrarch root-stele according to Van Tieghem's type 3. I have examined no intermediate forms which would suggest whether this symmetry is derived from that of an ancestor resembling Muscari armenaicum, or more remotely from one with the vascular structure which I have called type 5 (Galtonia, Dipcadi).

In Muscari comosum, Hyacinthus orientalis, Scilla festalis, Salisb., and Ornithogalum sulphureum, more than two lateral traces from the cotyledon enter the hypocotyledonary stele, and the two main traces form less than half the root-stele. Such a possibility was suggested by the structure of seedling $\mathrm{A}_{2}$ in Muscari neglectum. It is worth notice that the main traces of Muscari comosum and Hyacinthus orientalis are distinguished not merely by their orientation in the sheath, but 
very commonly during the transition by the characteristic branching of their xylem in three directions. The median protoxylem ray when formed is as a rule suppressed in the course of the transition: now and then it persists and affects the symmetry of the root-stele.

Finally, in the three species Lachenalia Nelsoni, Scilla peruviana, and Ornithogalum exscapum, lateral bundles are either absent from the cotyledonary sheath, or, if present, they take but little share in the transition. The diarch root is formed from the much reduced main bundles, with more or less assistance from the plumular traces. The transition in these species approaches that characteristic of such bulbous genera as Allium and Lilium.

Lachenalia Nelsoni. The cotyledonary sheath contains three slender lateral bundles, as well as the two main bundles which lie side by side and have a common protoxylem group (cf. Eucomis nana). The lateral bundles of the cotyledon together with those of the plumule are all inserted on the midrib trace of the first leaf. The trace of the double bundle from the cotyledon and the single plumular trace take an equal share in the formation of the diarch root-stele. The plumular phloëm divides itself between the two phloëm groups of the cotyledon. The plumular protoxylem turns outwards. The group of protoxylem common to the two cotyledonary traces also turns outwards, and the diarch root is then complete.

Scilla peruviana. There are no lateral bundles in the cotyledon. The two main bundles form a double structure as in Eucomis. The double trace from this enters the hypocotyledonary stele together with a single plumular trace. Together they form a diarch root as in Lachenalia.

Ornithogalum exscapum. Two massive bundles run the whole length of the cotyledon. In the sheath they are placed very much as the bundles of Albuca (Pl. I, Fig. 2). A single plumular trace takes part in the transition, but seems to exercise no influence on the symmetry of the stele. 
Very great individual differences occur within the limits of this species. The transition follows type 5-that is, the phloëm of each cotyledonary trace branches in three directions, the xylem in two. This would normally lead to a tetrarch root, and does so in one seedling $\left(\mathrm{A}_{2}\right)$. In another $\left(\mathrm{A}_{3}\right)$ a very interesting variation is found (Diagram IV).

The phloëm groups at first behave in the usual way (Diagram IV, B), but before the branching is accomplished and four definite groups are formed, the original groups re-assert themselves, and the phloëm elements collect once more in two large masses. The four protoxylem groups are still distinct,
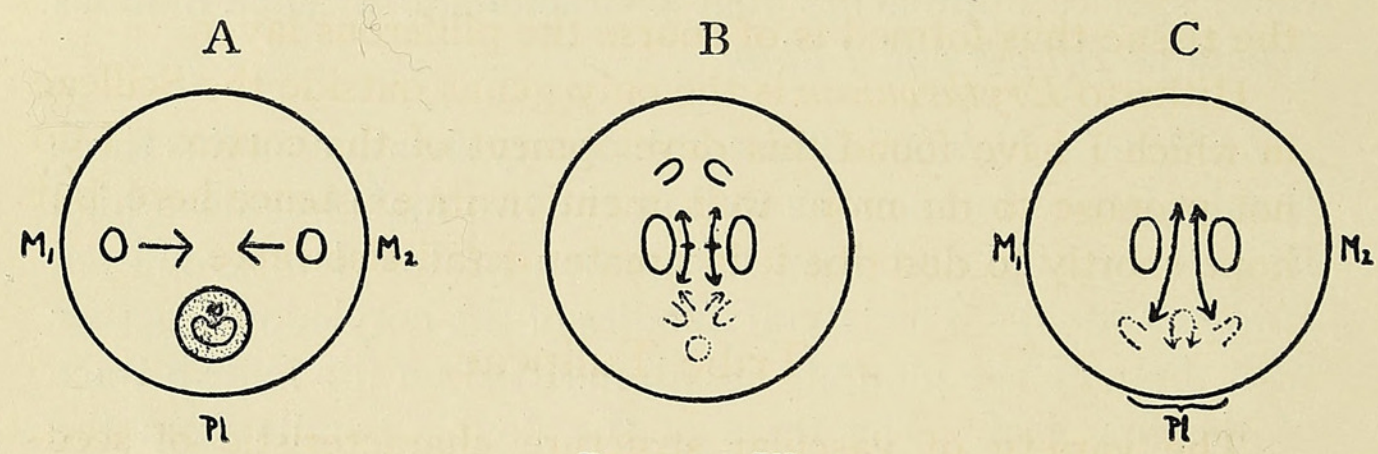

DiAgRAM IV.

but the right-hand branch of one group is not separated from the left-hand branch of the other by phloëm elements, and the four groups naturally fuse in pairs (Diagram IV, C). The diarch root-stele is then complete.

If we neglect the very small plumular trace which inserts itself on the stele during the transition without affecting its symmetry, this is precisely the structure characteristic of the Tulipeae, in which, however, the two cotyledonary traces are commonly reduced to a slender double bundle. But in Ornithogalum exscapum the size of the cotyledonary traces, their independence, and their behaviour during the transition in seedling $\mathrm{A}_{2}$, leaves no doubt as to their identity with the main bundles of Galtonia and Albuca.

Before leaving the Scilleae, I must mention an anatomical peculiarity of the root-cortex which is found in a number of species belonging to it. 
In most Monocotyledons the piliferous layer of the root is a direct continuation of the cell-layer lying immediately under the epidermis of the cotyledon. The absence of the epidermal layer causes an abrupt decrease in diameter at the junction of the root with the hypocotyl, and the 'collet' is defined by Van Tieghem as a plane passing through the axis immediately below the last row of epidermal cells.

The root of Albuca, however, has a greater diameter than the hypocotyl in the region where they join, and the same is true of many other species belonging to this tribe. The increase in girth is due to repeated tangential division in the cells of the outer cortical layer. The external layer of cells in the tissue thus formed is of course the piliferous layer.

Hitherto Erythronium is the only genus outside the Scilleae in which I have found this development of the cortex. I do not propose to do more than mention its existence here, but hope shortly to describe it in greater detail elsewhere.

\section{Tribe Tulipeae.}

The variety of vascular structure characteristic of seedlings belonging to the Scilleae is in strong contrast with the uniformity of type found in the Tulipeae. I have fully examined eight species belonging to four genera of this tribe, and with the exception of Erythronium the vascular symmetry of the cotyledon and the process of transition from stem to root are the same in all.

Fritillaria imperialis. The seedling of this species (PI. III, Fig. I) consists of cotyledon, hypocotyl, and primary root throughout the first season. The petiole of the cotyledon becomes flattened and acts as an assimilating organ. Neither foliage leaf nor cauline root is developed until the second season of growth. The primary root is very well developed.

The massive bundles run the whole length of the cotyledon. They lie close together in the sheath, but are quite distinct (Pl. III, Fig. 2). The plumule is still embryonic: its bundles become lignified lower down, where they unite to form 


\section{Sargant.-Theory of the Origin of Monocotyledons}

two traces. These traces are inserted on those of the cotyledon at the first node (Pl. III, Fig. 3).

At this point the transition to a root-like structure has already begun in the stele. The protoxylem of each main bundle is branching in two directions. The branches towards the top of the section have united with each other: those which have turned in the opposite direction are distinct, and have each joined a group of plumular xylem (P1. III, Fig. 3).

Below the node there are two crescent-shaped xylem masses, each crescent partly encloses a very well-defined circular group of phloëm (Pl. III, Fig. 4). The extended protoxylem covers the convex surface of either crescent, but though the crescents lie close together and present their convex outline to each other, the protoxylem elements of the two bundles are united only at one point near the top of the stele.

Very little below this, the two massive xylem crescents meet in the centre of their convex surfaces, and the protoxylem sheath on both sides is broken in the centre. There are now four protoxylem rays stretching out towards the horns of the crescent. They are united in pairs to form the groups $p x_{2}$ and $p x_{3}$ in Fig. 5, Pl. III. The whole structure is that of a diarch root with the protoxylem rays extended tangentially.

So far the transition is essentially that characteristic of the Tulipeae (Diagram V). Two cotyledonary traces have formed a diarch root-stele according to Van Tieghem's type 1, that is, by branching of the xylem and fusion of adjacent branches. But in $F$. imperialis the process does not stop there. The protoxylem elements creep round the horns of the crescents until they meet on either side and form two groups external to the two phloëm-masses. Each phloëm-mass breaks into two (Pl. III, Fig. 6), and the root is then tetrarch. In a similar way it becomes first hexarch and then heptarch a little lower down.

This variation on the type is doubtless due to the persist- 
founded on the Structure of their Seedlings. 25

ence of the primary root and its physiological activity which renders a considerable girth necessary.

The two cotyledonary traces of the slighter seedling of Fritillaria alpina form a diarch root-stele in much the same way. It afterwards becomes tetrarch by branching of the phloëm and division of the protoxylem, and the whole transition recalls that of Ornithogalum exscapum. This resemblance is probably accidental.

Tulipa praccox and Tulipa sp. (from Calcutta).

Two bundles run the whole length of the cotyledon and possess a common protoxylem group. They are orientated in the way characteristic of double bundles (A, Diagram V).

A

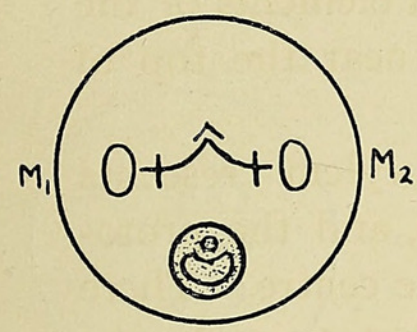

$\mathrm{B}$

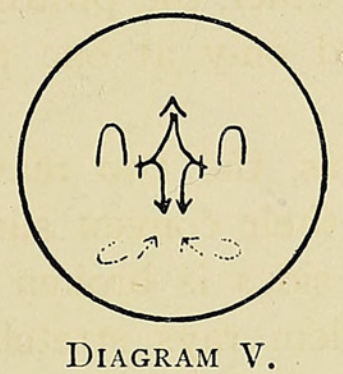

C

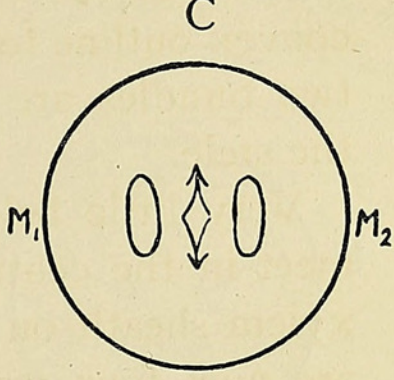

Two plumular traces are inserted on the cotyledonary traces, as in Fritillaria (B, Diagram V). A diarch root-stele is formed from the cotyledonary traces : the phloëm groups are continued straight down into the root, while the single protoxylem group branches to form a second on the opposite side of the xylem plate (Diagram V). In both species the protoxylem groups of the root are somewhat extended tangentially, and the whole xylem plate is shaped like a dumb-bell. The rootstele, however, remains diarch.

In the three species of Lilium which I have examined (Lilium sp., L. Henryi, L. croceum), the double trace of the cotyledon is even more reduced than in Tulipa, but the transition takes place in precisely the same way.

Erythronium Hartwegi is the only species I have examined from this tribe which does not follow in essentials the method 
of transition indicated in Diagram V. The cotyledon possesses three bundles throughout, and they are continued downwards into a triarch root formed according to Van Tieghem's type I. I have not so far hit on any intermediate form which would connect this structure with that of Tulipa and Lilium. The anatomy of the seedling, however, may possibly be modified by the very early transformation of the first leaf into a dropper (Irmisch). This occurs also in both species of Tulipa.

3. Tribe Asphodeleae.

In this tribe I have examined eleven species belonging to eight genera. There is no definite symmetry characteristic
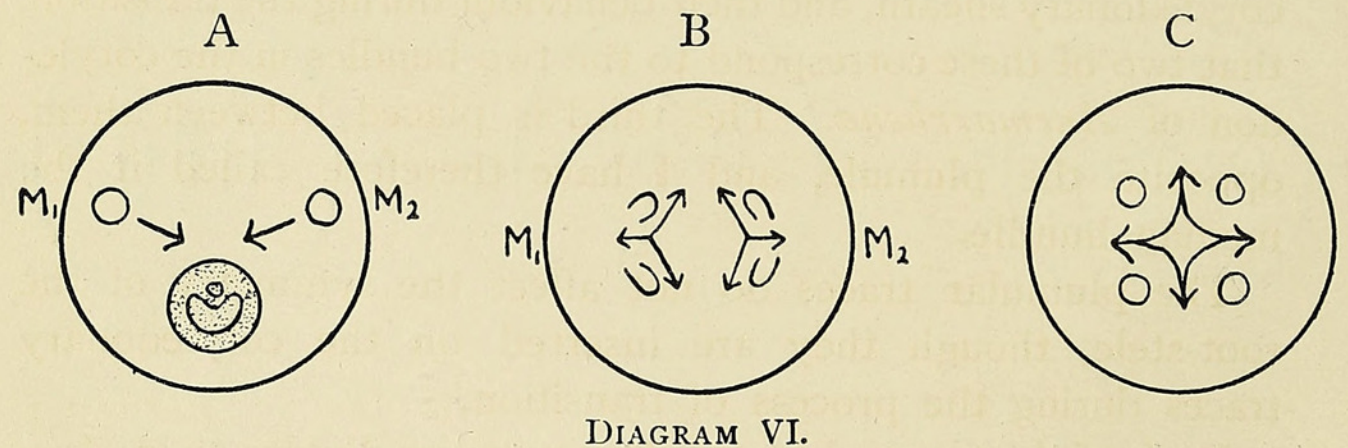

of the tribe as in Tulipeae, but, with the exception of Bulbine annua, the vascular structure of all the species examined can be linked with great probability to that of Anemarrhena (Diagram VI).

The seedling of Anemarrhena asphodeloides has been described elsewhere in detail (Sargant, 34). It resembles that of Albuca, except in possessing no lateral bundles in the cotyledon, and in the regular formation of a tetrarch root.

Asphodeline liburnica. The cotyledon contains two massive bundles throughout, which are quite distinct but orientated in the characteristic way-that is, with their protoxylem groups directed towards each other. The symmetry of the rootstele is sometimes derived from the cotyledonary traces only, 
and when this is the case the root is tetrarch or pentarch, and the transition follows the Anemarrhena type more or less closely.

When, as is more commonly the case, plumular traces enter the stele and take part in the transition, the process is always irregular, and the root becomes $5^{-7}$ arch.

Similar irregularities are found in the allied genus Asphodelus. In $A$. albus and $A$. cerasifer there are two cotyledonary bundles as in Asphodeline, but plumular traces play a greater part in the transition, and the likeness to Anemarrhena is more obscure.

The relationship to Anemarrhena is particularly clear in Asphodelus fistulosus. It possesses three massive bundles in the cotyledon, and it is clear from their position in the cotyledonary sheath, and their behaviour during the transition, that two of these correspond to the two bundles in the cotyledon of Anemarrhena. The third is placed between them, opposite the plumule, and I have therefore called it the median bundle.

The plumular traces do not affect the symmetry of the root-stele, though they are inserted on the cotyledonary traces during the process of transition.

Each of the two main cotyledonary traces divides as in Anemarrhena (Diagram VI). The xylem branches in three directions, and the median branch of the three bisects the phloëm group behind it. Of the four lateral xylem branches formed from the two main traces, the two directed towards the plumule unite, and the opposite pair would do so too-forming a tetrarch root as in Anemarrhena-but for the presence of the median trace on that side. The xylem of this trace branches to right and left, each branch fusing with the adjacent lateral branch from a main trace. The phloëm group does not divide, but is continued downwards in situ. Thus a pentarch root is formed.

Eremurus turkestanicus and E. spectabilis also possess a median bundle in the cotyledon, placed as in Asphodelus fistulosus. The two main bundles behave during the tran- 
sition exactly as those of Anemarrhena (Diagram VI), and the median bundle plays the same part that it does in Asphodelus fistulosus. The root sometimes becomes pentarch in the same way.

More commonly, however, a plumular trace-the midrib of the first leaf-enters the hypocotyledonary stele directly opposite the median trace of the cotyledon, and divides its xylem between the adjacent branches from the main cotyledonary traces. The phloëm of this plumular trace is continued downwards into the root-stele without division. When this occurs the root is hexarch.

In all the species hitherto described from this tribe, two main bundles are present in the cotyledon. Their identity with the bundles of Anemarrhena cannot be mistaken, in spite of the irregularities introduced by the entrance of plumular traces, or a minor cotyledonary trace, into the hypocotyl. Of the four species examined, but not yet described, Bulbine annua may be dismissed at once. The symmetry of the triarch root is determined by the three traces of the first leaf. The two distinct cotyledonary traces are inserted on two of them, and the transition follows Van Tieghem's type 3.

Three species remain, Chlorogalum pomeridianum, Anthericum Liliago, and Arthropodium cirrhatum. The two main. bundles of the cotyledon appear in all of them, but they are much reduced, and are associated in the hypocotyl with plumular traces which take a well-defined part in the transition. I have examined no forms which are clearly intermediate between Anemarrhena and Chlorogalum. Such a series as that which leads step by step from Albuca to Muscari armenaicum (Plates I and II) would, however, account completely for the structure of Chlorogalum, and probably such a series of links either exists now or has once existed. Arthropodium is quite clearly linked to the less reduced Chlorogalum through Anthericum.

Chlorogalum pomeridianum. The cotyledon, which remains underground and within the seed to the end (Pl. IV, Fig. I), 
contains two bundles which are quite distinct from each other though close together. Near the base of the sheath the bundles so far unite that they have a common protoxylem group, and they then form a typical double bundle such as we find in Allium (cf. P1. V, Figs. 2 and 3).

The plumular bundles unite to form a single trace which then divides into two branches, $P l_{1}, P l_{2}$, and these advance to meet the double cotyledonary trace $\mathrm{M}_{1}+\mathrm{M}_{2}$ at the first node (P1. IV, Fig. 2). The protoxylem of the double trace has formed three groups already ( $p x_{1}, p x_{2}, p x_{3}$ in Fig. 2). They represent two branches from the xylem of $\mathrm{M}_{1}$ and two from that of $M_{2}$. The single group $p x_{1}$ is formed by the early fusion of two adjacent branches : $p x_{2}$, belongs to $\mathrm{M}_{1}$ and $p x_{3}$, to $\mathrm{M}_{2}$.

A little lower down, the stele threatens to become diarch (P1. IV, Fig. 3). The phloëm from $\mathrm{M}_{1}$ has met half the plumular phloëm on one side of the stele, and that from $\mathrm{M}_{2}$ has met the other half on the opposite side. The protoxylem groups within the phloëm $\left(p x_{2}, p x_{3}\right.$, in Fig. 3) seem about to be obliterated. But they recover themselves later, and the root becomes typically tetrarch (Pl. IV, Fig. 4).

Two phloëm groups in the tetrarch root are derived from the plumule and two from the cotyledon. One protoxylem group ( $p x_{1}$, Fig. 4) is purely cotyledonary and one purely plumular $\left(p x_{1}^{\prime}\right)$. With regard to the two remaining groups of protoxylem, they appear in the young seedlings I have examined to be derived from the cotyledon, but it is very possible that in older seedlings they would be found to receive elements from the plumular traces. If so, the transition would be precisely comparable with that of Muscari armenaicum, seedling $\mathrm{A}_{5}$ (Diagram II).

Anthericum Liliago. The two bundles of the cotyledon are more reduced than those of Chlorogalum. They are united by a common protoxylem group throughout their course, and in fact appear as a typical double bundle in the upper as well as the lower part of the cotyledon. 
The insertion of the plumular traces takes place as in Chlorogalum (Pl. IV, Fig. 6): the three traces of the first leaf $(\mathrm{A}, \mathrm{B}$, and $\mathrm{C}$, in Fig. 6) unite with each other and then divide into two branches $\left(P l_{1}, P l_{2}\right)$ which join the two cotyledonary traces $\left(\mathrm{M}_{1}, \mathrm{M}_{2}\right)$.

The root-stele when first formed suggests a diarch structure, and this appearance persists for some time. In Fig. 7 (Pl. IV) there are only two phloëm groups, but the protoxylem elements internal to them are quite distinct $\left(p x_{2}, p x_{3}\right)$. They finally disappear a little further down, and the root appears truly diarch.

Finally, in the seedling $B_{1}$ figured in Fig. 5, the group $p x_{2}$ recovers itself and divides the phloëm group lying outside it into two. The opposite phloëm group remains single, and the corresponding group of protoxylem, $p x_{3}$, is suppressed permanently. The root of course is triarch.

In the two other seedlings examined both lateral protoxylem groups reappear after a temporary eclipse, and the stele of the root is tetrarch.

Arthropodium cirrhatum. The two bundles of the cotyledon, though slender and lying close together, are distinct from each other until they reach the base of the cotyledon. Here their protoxylem groups unite, and they assume the typical double structure.

The plumular traces unite with those of the cotyledon just as in Chlorogalum and Anthericum (PI. IV, Fig. 9). A diarch root-stele is formed ( $\mathrm{Pl}$. IV, Fig. IO). During the process two lateral protoxylem groups appear, and they have not quite vanished in Fig. IO $(+,+)$. The two massive phloëm groups, however, formed by the union of a cotyledonary with a plumular mass of phloëm on either side of the stele, are never broken up. The root remains diarch to the end.

The vascular symmetry of Arthropodium is so far reduced from that characteristic of Chlorogalum, that it precisely resembles the Allium symmetry (Diagram VII). 
founded on the Structure of their Seedlings. 3I

\section{Tribe Allieae.}

Nine species representing four genera have been examined from this tribe. The vascular structure of the hypocotyl is much reduced, and is identical in all the species examined, except Milla biflora.

Allium neapolitanum. The seedling $\mathrm{A}_{\mathbf{4}}$ from which the sections drawn in Figs. I-5 on Pl. V were cut was very young, and the traces but slightly lignified. The two bundles of the cotyledon are united by their common protoxylem group throughout their course. This protoxylem group
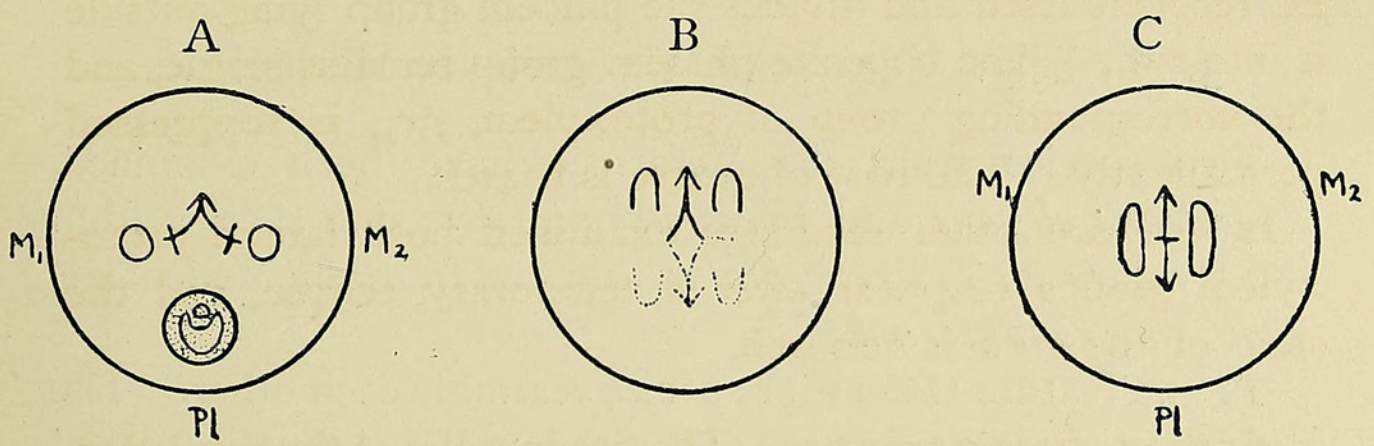

Diagram VII.

begins to turn outwards early (Pl. V, Figs. I and 2). The plumular traces in seedling $\mathrm{A}_{4}$ are so embryonic that only one protoxylem element is lignified at the first node (Pl. V, Fig. 3): in the older seedling $B$ it is clear that two traces from the plumule join the stele. Their phloëm groups run into those of the cotyledonary traces: their xylem will form one-half of the xylem plate (Pl. V, Figs. 4 and 5). When the series of sections cut from seedling $\mathrm{A}_{4}$ is examined with attention, it is clear that one protoxylem group of the diarch root is derived from the cotyledonary, the other from the plumular, traces. Each of the two phloëm groups is derived from both.

The method of transition represented in Diagram VII is common to all the six species of Allium examined ( $A$. neapolitanum, $A$. Cepa, A. Porrum, $A$. serufschanicum, $A$. asca- 


\section{Sargant.--Theory of the Origin of Monocotyledons}

lonicum, $A$. angulosum) as well as to Bloomeria aurea and Brodiaea lactea. In the two species last named the bundles of the cotyledon are distinct throughout. Indeed, the cotyledonary sheath of Bloomeria, with its two distinct and rather massive bundles, recalls the symmetry of the Asphodeleae.

Milla biflora also possesses two distinct bundles in the cotyledon, which are less reduced during the transition than those of Allium. A small plumular trace also enters the hypocotyledonary stele, and each of the three xylem groups branches to right and left. The phloëm remains in situ. A triarch root is formed according to Van Tieghem's type I.

5. Tribes : Veratreae, Uvularieae, Medeoleae.

Two species from the Veratreae have been examined, Zygadenus elegans and Veratrum nigrum; one species from the Uvularieae, Tricyrtis hirta; and one from the Medeoleae, Trillium grandiflorum.

In one feature these four species resemble each other. The cotyledon contains a single and rather massive bundle, placed in the position of a midrib, and sometimes accompanied by lateral bundles. This central bundle opens out in the neighbourhood of the first node into a double trace resembling that of Allium.

Zygadenus elegans. The cylindrical cotyledon contains but one bundle throughout: a section near the top hardly suggests a double structure in the phloëm (Pl. V, Figs. 7 and 8), but it is clear lower down (Figs. 9 and I0) and also throughout the transition. The plumular bundles which take part in it separate into two branches: in Pl. V, Fig. II these are seen advancing to meet the cotyledonary trace exactly as in Allium (cf. Fig. 3).

The phloëm groups of the cotyledonary trace are now quite distinct, and separated from each other by the whole xylem. The xylem itself is in two masses, between which 
are inserted the protoxylem elements. They are not yet external. In the diarch root (Pl. V, Fig. I2) one protoxylem group is derived from the double cotyledonary trace and the other from the plumular traces. The two phloëm groups are of mixed origin.

The transition in Zygadenus elegans resembles that of Allium precisely, except for the more intimate union of the two bundles in the cotyledon.

Veratrum nigrum. The cotyledon contains a single massive bundle throughout its length, but in the sheath two or more slender lateral bundles appear. These are ultimately inserted on the plumular traces.

During the transition two crescents of xylem appear, each with a protoxylem group at either horn. One crescent is derived from the xylem of the cotyledonary double trace: the other from the xylem of the lateral and plumular traces. The four protoxylem groups are separated by four phloëm groups : two of these are derived from the double trace and the other two from lateral and plumular traces.

In the absence of sections from allied species the homology of this transition must remain uncertain. It would be very readily derived from súch a form as Scilla sibirica (Diagram III).

Tricyrtis hirta. The vascular symmetry of this seedling presents many interesting features, but it cannot be described in detail here. The mature plant is a herbaceous perennial with a short creeping rhizome. The hypocotyl of the seedling is unthickened and of some length.

The cotyledon is leaf-like, and contains but one bundle. This opens out into a very well-marked double bundle a little above the first node. Two plumular traces are inserted on the double trace at the first node (A, Diagram VIII). When the insertion is complete no sign of transition to root-structure is observed: the double trace-now surrounded by an endodermis-is continued downwards in the elongated hypocotyl (B, Diagram VIII). Cauline roots are given off from it. 
The transition from stem- to root-structure takes place rather suddenly at the base of the hypocotyl (C, Diagram VIII). It resembles that of Fritillaria and Lilium.
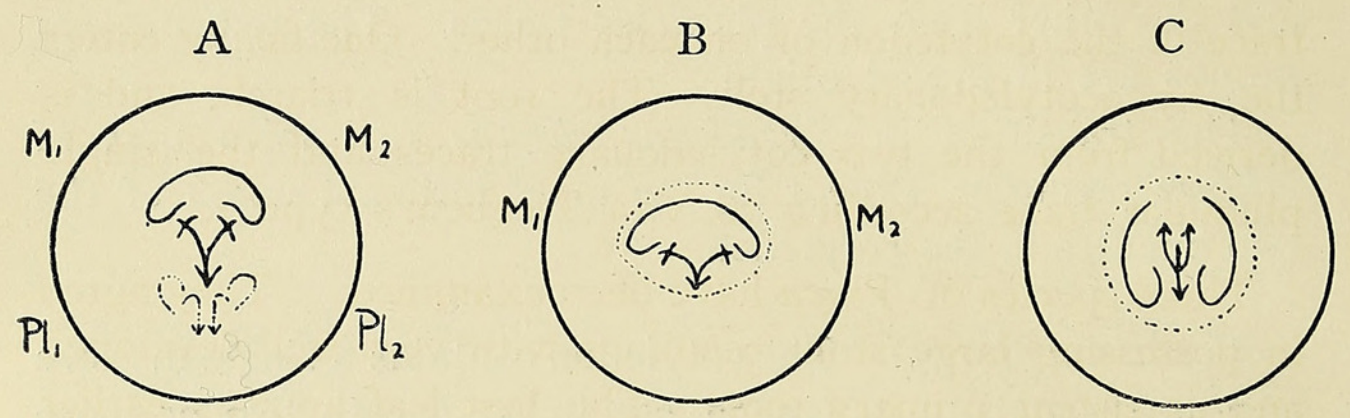

DiAGRAM VIII.

Trillium grandiflorum. The cotyledon contains a main bundle and two lateral ones. The main bundle opens out above the first node, and is clearly a double structure. One phloëm group and two protoxylem rays of the triarch root are derived from it: the rest from the lateral and plumular traces.

There are points in this transition which suggest that of Veratrum, but I have not examined any allied species, and do not venture to draw a definite conclusion.

\section{Tribes: Dracaeneae, Asparageae, Aloineae.}

The species examined from these tribes are all of woody habit, or climbers. The structure of the seedling has been in most cases adapted to the conditions of life by changes in its vascular structure so profound that they disguise the primitive symmetry more or less completely. In nearly all cases the plumular traces enter the hypocotyledonary stele, and they commonly take the larger share in determining its symmetry.

Five species representing three genera have been thoroughly examined among the Dracaeneae.

Cordyline australis. The seedling resembles that of Muscari externally, but is larger. The first leaf shows early. There are two bundles in the cotyledon which are quite distinct until 
they get near the base of the sheath. In that region they approach each other until the protoxylem elements unite to form a single group.

The plumular traces are inserted either on the double trace of the cotyledon or on each other. One finally enters the hypocotyledonary stele. The root is triarch, and is derived from the two cotyledonary traces and the single plumular trace according to Van Tieghem's type I.

Three species of Yucca have been examined. They agree in possessing large stout seedlings with very well-developed and persistent primary roots. The first leaf appears earlier in $Y$.gloriosa and $Y$. aloifolia than in $Y$. arborescens.

Yusca arborescens. The cotyledon contains a number of massive bundles. These are reduced to six or seven in the neck of the cotyledon, just outside the seed, and they are continued downwards into the sheath, and form a semi-circle in the thickest part of it. Four smaller bundles are commonly found in the wings of the cotyledonary sheath.

The plumular traces are in the end all inserted on the traces of the cotyledon before the transition to a root-structure begins. The stele of the hypocotyl contains cotyledonary traces only. The six or seven main traces, which are all alike, are continued directly into it, and a seventh or eighth trace is added by the fusion with each other of the four wing-traces.

The root when first formed is heptarch or octarch. The protoxylem has become external by the branching of the xylem groups and the fusion of adjacent branches in pairs.

Yucca aloifolia. Three bundles are found in the cotyledon : when they reach the sheath the central one opens out into a typical double bundle. No wing-bundles appear.

The four cotyledonary bundles are continued downwards into the hypocotyl, and three traces-ultimately reduced to two-enter it from the plumule. The root is hexarch, and the transition to a root-structure takes place as in $Y$. arborescens. 


\section{Sargant.-Theory of the Origin of Monocotyledons}

Yucca gloriosa. There are four bundles throughout the length of the cotyledon: within the seed, and again in the lower part of the sheath, the two median bundles approach each other and their protoxylem groups unite. The structure of the cotyledon is then precisely that found in $Y$. aloifolia.

The four cotyledonary traces are continued into the hypocotyl, where they are joined by two or three from the plumule. All the traces behave alike during the transition : the xylem groups branch to right and left, and adjacent branches unite with each other. The root is either hexarch or heptarch.

Dracaena Draco is the only species I have examined from this genus.

The seedling is very robust: the plumular bud is developed early, and the primary root is particularly long, thick, and persistent. The cotyledon is merely a sucking organ, and it remains for a long time within the large seed, never appearing above ground.

There are seven bundles in the neck of the cotyledon where it emerges from the seed. Six are arranged in pairs to form three double bundles-each with a common protoxylem group. The seventh is single. This structure is continued into the sheath. As they descend, the three common protoxylem groups become more and more external. In this way the transition to a root-structure begins before the cotyledonary traces enter the hypocotyl.

The plumule contributes many traces to the hypocotylsix to eleven in the seedlings I have examined-and the transition to a root-structure is very far advanced before they enter it. Both in cotyledon and plumule it proceeds-as in Yucca-according to Van Tieghem's type I. The resulting root is polyarch. I have found as many as eighteen phloëm and xylem rays in it.

The four last species have been described at some length, because they display characters common to most of the arborescent forms which belong to this and allied orders. The primary root is persistent, and the insertion of the plumule 
on it becomes a question of importance, particularly as the first foliage leaves are in general the earliest assimilating organs-the cotyledon commonly remaining within the seed. An early development of the plumule is usual, and when this occurs some plumular traces are commonly found in the hypocotyl. (Cf. Yucca gloriosa and $Y$. aloifolia with $Y$. arborescens.) This arrangement is useful in two ways: it secures uninterrupted communication between the plumule and the primary root, and it increases the girth of the latter. Among Monocotyledons a root which is to attain to any considerable diameter must be planned on a generous scale from the beginning, for there is no secondary thickening to provide fresh vascular tissue as it is needed.

Similar co-operation between plumule and cotyledon is found in the two species of Asparagus which I have cut, $A$. officinalis and $A$. decumbens. In both the hypocotyl contains both plumular and cotyledonary traces, which are all alike and behave in the same way during the transition.

The central double bundle found in the cotyledons of Yucca gloriosa and $Y$. aloifolia probably represents the two cotyledonary bundles of Cordyline, but it is possible that there may be no morphological connexion here. In Dracaena the three double bundles are no doubt formed for physiological reasons, and the double bundles of Yucca may arise in a similar way.

Among the Aloineae I have examined six species of Alö and two of Gasteria. Their seedlings resemble each other very closely both in external form and internal structure.

The adaptation of these seedlings to life in a dry hot climate is very clear, and has profoundly affected their vascular structure. The cotyledon is modified to serve as a sucking organ in the upper part and as a water-jacket lower down. It contains two distinct bundles with massive phloëm groups.

The vascular symmetry of the very short transitional region is most simply explained by supposing that of the root-stele to depend solely on the three or four plumular traces which 
enter it. The cotyledonary traces are inserted on them, sometimes before the transition to a root-structure begins, but more often while it is still in progress. The root is either triarch or tetrarch. In Aloë Buchanii the cotyledonary traces seem occasionally to exercise some influence on the symmetry of the root-stele. Four seedlings were examined from that species, and in two of them the root is diarch.

The method of transition is commonly but not invariably Van Tieghem's type 3. That is, the xylem groups rotate in situ, while the phloëm groups branch to right and left of them, and the branches from adjacent groups unite with each other in pairs.

\section{B. Monocotyledons not included in the order Liliaceae.}

In working out the seedling structure of the Liliaceae I have paid most attention to the four great tribes, Asphodeleae, Allieae, Scilleae, and Tulipeae, which may be considered as including the typical representatives of the order. The observations made on species from outlying groups are scattered, and serve for the most part merely to show that the vascular structure of their seedlings is not dissimilar from one or other of the central types.

The seedlings of Allium and Zygademus, for example, are figured on the same plate and can readily be compared $(\mathrm{Pl} . \mathrm{V})$. The structure of the cotyledon is the same in both, except that the cotyledon of Allium contains two bundles united by a common protoxylem group (Pl. V, Figs. I and 2), while that of Zygadenus has a single bundle (Figs. 7 and 8).

Now the most salient feature distinguishing the vascular symmetry of the cotyledon in most Liliaceous seedlings is the absence of a midrib. In the first foliage leaf there are commonly three bundles, of which the central one or midrib is by far the best developed. There may be five, seven, nine, or even more bundles in each foliage leaf, but the number is 
always odd, and the lateral bundles are always arranged symmetrically on either side of the midrib.

The cotyledon of the same species, however, commonly possesses two equivalent bundles, and if others are present they are arranged symmetrically with regard to both. These main bundles are often distinct and widely separate, as in Albuca, Galtonia, Anemarrhena, Bloomeria, Alö̈, and other genera. When they approach each other more closely, as in Muscari armenaicum (P1. II, Fig 5) and Fritillaria imperialis (P1. III, Fig. 2), they occupy the position of a midrib. This is still clearer in Allium, Lilium and many other genera, in which the two main bundles are much reduced in size, and are united by a common protoxylem group either in the sheath of the cotyledon only or throughout its length (P1. V, Figs. I and 2).

The cotyledon of Zygadenus with its solitary bundle seems at first sight to be an exception to this rule. During the transition, however, this bundle opens out into a double structure perfectly comparable with that of Allium. In the allied genus Veratrum the central bundle of the cotyledon does not open out in this way during the transition, and but for the relationship with Zygadenus we might take it for a true midrib.

Another very striking example of the same kind is found in the two species Yucca aloifolia and $Y$. gloriosa. The cotyledon of $Y$. aloifolia contains three bundles, and the central one occupies the position of a midrib. During the transition this bundle opens out into the characteristic double structure (ante, p. 35). In the cotyledon of $Y$.gloriosa there are four bundles, but just before the transition begins the two central bundles approach each other so closely that their protoxylem groups unite. There can be no doubt as to the double origin of the 'midrib' thus formed, and it strengthens the presumption that the central bundle of $Y$. aloifolia is also double.

From these examples it is quite clear that the whole case for the absence of a true midrib in the cotyledon of Liliaceous 
seedlings depends at present on the comparative study of the four central tribes within that family. The passage from two massive bundles to a reduced double bundle in the position of a midrib has been traced step by step within those tribes. From the double bundle of Allium to the single one of Zygademus is an easy step, and if the 'midrib' of Zygademus be of double origin, we can hardly, in the absence of further evidence, venture to assert that the midrib of Veratrum is single.

Similar reasoning applies to other characters of the vascular symmetry.

The observations which follow on the vascular system of seedlings belonging to other monocotyledonous families were made, as explained before (p. I), on material already collected, and were purposely extended over a wide field. They led in the end to the selection of the Liliaceae for more detailed study, and in the light of the results obtained from it these preliminary observations have acquired a new value.

Many of the seedlings examined show a marked likeness in the form of their vascular skeleton to the seedlings of Liliaceous species. Such are the forms commonly found within the Amaryllidaceae and Iridaceae. Anthurium is a striking instance from the Aroideae.

The Palmae and Scitamineae, on the other hand, present types of their own. There is no embryological evidence to show that these are genetically connected with any Liliaceous form. But we may fairly ask whether their vascular structure is consistent with the theory of a single member formed by the union of two similar cotyledons.

\section{Amaryllidaceae.}

Six species belonging to four genera have been examined from this family.

Four species-Alstroemeria sp., Bravoa geminiflora, Agave spicata, and $A$. Rovelliana-follow Liliaceous types in the vascular structure of their seedlings.

The seedlings of Doryanthes Palmeri and D. excelsa are 
remarkable both in external form and in their vascular symmetry. I shall describe the latter at some length, as it offers points of interest, though I believe it to be in all probability derived from some form resembling Agave rather than of more primitive character.

Alstroemeria (garden variety). The cotyledon remains in the seed as a sucking organ. It contains two bundles which, though distinct from each other down to the middle of the sheath, are close together, and occupy the position of a midrib. Just above the entrance of the plumular traces into the stele, the two cotyledonary traces approach each other, and their protoxylem groups unite. They now form a double bundle resembling that of Allium (P1. V, Figs. I and 2). The plumular bundles unite to form two massive traces, and these enter the hypocotyl at the same time with the double trace from the cotyledon. The transition to a diarch root-stele takes place exactly as in Arthropodium (p. 30), but the stele subsequently becomes tetrarch. This takes place by the formation of new protoxylem groups (cf. Fritillaria alpina, p. 25); not as in Chlorogalum by the survival of two which were at first suppressed.

Bravoa geminiflora. The cotyledon remains within the seed as a sucking organ. It contains four bundles in the sheath, all quite distinct from each other. Twó, distinguished from the others by their size and position, represent the main bundles. These two approach each other in the transitional region without uniting. The plumular traces insert themselves on those from the cotyledon, and the root-stele is triarch. Its formation seems to be governed by cotyledonary traces only.

Agave spicata. The whole seedling is succulent. The cotyledon, after sucking out the food from the endosperm, emerges from the ground as a green fleshy spike of triangular section, carrying the seed-coats on its apex. It contains four bundles, of which two, from their size and position, can be identified as the main bundles. There is a comparatively long hypocotyl in these seedlings, with a stele 
containing three or four traces from the cotyledon, and these retain their stem-structure for some distance downwards. In one seedling I found six traces, for two entered it from the plumule, but this is exceptional. - As a rule, a portion of each plumular trace is inserted on the ring of cotyledonary traces at the first node, without altering the symmetry of the transition, but the rest of the plumular stele is continued directly downwards, and becomes the stele of the first cauline root.

The structure of cotyledon and hypocotyl in A. Rovelliana seems essentially the same as that of $A$. spicata.

Doryanthes Palmeri The seedling is very stout and fleshy. The first leaf is rolled upon itself, and forms a trumpet-shaped cylinder which is in a straight line with the hypocotyl and primary root. The cotyledon projects horizontally from the axis. Its blade is a flat, thick disc, covered for some time by the brown seed-coats. It is attached to a very short petiole which clasps the axis with its massive sheath.

There are four main veins in the cotyledon, and they all enter the axis through the petiole. The plumular bundles form a ring of eight traces, which are joined at the node by the four traces from the cotyledon. These enter the stele in pairs, each pair displacing one of the plumular traces.

The stele of the hypocotyl now contains ten distinct bundles. Within this circle are the two plumular traces displaced by the entrance of the cotyledonary traces. The displaced traces are not adjacent to each other, but separated by two others in the original circle of eight, and with these two they now unite.

The hypocotyl in this species is comparatively long, $3 \mathrm{~mm}$., even in quite young seedlings. The transition from a ring of ten stem-bundles to a 10-arch root-stele takes place gradually by branching and rotation of the xylem groups onlyVan Tieghem's type I.

The seedling of $D$. excelsa resembles that of $D$. Palmeri both in its external characters and its vascular symmetry. 
For some time I was tempted to look on Doryanthes as a genus in which the seedling possessed characters more primitive in some respects than those of Anemarrhena. The two pairs of bundles, though distinct throughout, might be identified with the two massive bundles in the cotyledon of Anemarrhena, each of which behaves like a double bundle during the process of transition. The fact that the two pairs of cotyledonary traces enter the plumular stele at two distinct points suggested at first their origin from distinct members, but the arrangement may be merely adaptive to secure greater mechanical stability at the insertion of the cotyledon.

Until the seedlings of allied forms have been examined there can be no further comparative evidence concerning the origin of the peculiar vascular structure of Doryanthes. The seedlings of Agave and Bravoa-two genera nearly related to Doryanthes by their mature characters-are, as we have seen, designed on a Liliaceous model. I am inclined to believe the vascular symmetry of the Doryanthes seedling to be derived from that of some form resembling Agave. There are two reasons against supposing it primitive.

In the first place the seedling of Doryanthes is, both anatomically and in external form, of the shrubby or arborescent type, which is, as a rule, much modified in response to its environment. In the second, the floral structure of Amaryllids is clearly derived from the Liliaceous type, and we are therefore less likely to find a primitive form among them than within the Liliaceae.

\section{Iridaceae.}

Four species representing two genera have been examined from this family.

The three species of Iris, I. sibirica, I. Boissieri, and an unnamed species from China, agree in possessing a single massive bundle which runs the whole length of the cotyledon, and opens out into a double bundle of characteristic form near the base of the sheath. Plumular traces take part in the transition to a root-structure, and the root is tetrarch (Iris sp. 


\section{Sargant. - Theory of the Origin of Monocotyledons}

and I. sibirica) or triarch (I. Boissieri). The root of Iris $s p$. appears diarch when first formed, but very soon becomes tetrarch, and the whole process of transition, so far as it could be followed in the rather old seedlings, recalled that of Chlorogalum (p. 29).

Freesia $s p$. (garden variety). The cotyledon contains three bundles in its lower part or sheath, and the central one appears double just above the first node. One plumular trace at least takes part in the transition. The root is tetrarch.

\section{Aroideae.}

Three species representing three genera have been examined from this family; Arum maculatum very thoroughly, the others in less detail.

The structure-internal and external-of the Arum maculatum seedling has been described elsewhere (36). The seed ripened in the summer may germinate before winter, or remain dormant until the spring. In either case no part of it appears above ground until the second spring after the seed has been sown.

The apex of the cotyledon remains within the seed as a sucking organ, while the lower part is transformed into a cylinder which sheathes the young stem-bud and is terminated by the hypocotyl. This begins to be thickened in the early stages of germination, and it swells into a tuber as the stores of food are transferred to it from the endosperm through the bundles which run down the cotyledonary tube. By the end of the summer following the sowing of the seed, the whole cotyledon, having emptied the seed of its food-supplies, is detached from the tuber. The stem-bud is exposed by the removal of the tube which has hitherto surrounded it, and in the following spring the first green leaf pushes through the soil.

The vascular system of the cotyledon has been profoundly modified by its peculiar habit. Of its five bundles the central one is larger than the others, but it never appears double. The plumular traces are inserted at the first node on those 
from the cotyledon. They rarely affect the symmetry of the root-stele, which is commonly triarch. It depends on the central trace from the cotyledon, and a lateral trace on either side of it. Each of these lateral traces is formed by the fusion of a pair of lateral bundles. The transition takes place according to Van Tieghem's type 3. The xylem groups are continued straight downwards, the protoxylem becoming external on the way, and each phloëm group divides, the right-hand segment of one uniting with the left-hand segment of the next.

Nothing in the vascular symmetry of Arum suggests a relationship with any Liliaceous type. All that can be said is that the possibility of such relationship is not excluded. The seedling of Arum maculatum is hardly more unlike that of Anemarrhena in its vascular structure than is that of Veratrum, for instance.

The seedling of Arisaema speciosum resembles that of Arum in many points. The tuber is already formed very shortly after germination, and the first green leaf makes its way out of the cotyledonary sheath early in the first season of growth. The cotyledon contains seven or nine bundles, and the primary root is either triarch or tetrarch.

Anthurium Bakeriamum differs completely from the genera just described both in the external form and in the internal structure of its seedling. The cotyledon remains underground -its apex enclosed within the endosperm of the seed. The petiole of the cotyledon is short, and its base is expanded into an open sheath which shelters the plumule without enclosing it. The first leaf develops early. It breaks through the soil and becomes green, while its base sheathes the younger leaves and the growing point. They are thus safely packed between the cotyledon and the first leaf.

Sections through the apex of the cotyledon as it lies within the endosperm show two bundles within it. They unite before passing into the petiole, and the bundle which enters the sheath of the cotyledon is apparently single. During the transition, however, it opens out into a double bundle. 
A single trace from the plumule approaches the double cotyledonary trace, and with it forms a diarch root-stele. The transition from stem to root takes place precisely as in Zygadenus (Pl. V, Figs. 9-I 2).

These facts certainly suggest that Anthurium is a form intermediate between the typical Liliaceous type and that of Arum and Arisaema, and this is the position assigned to it by systematic botanists on the evidence of its floral structure.

If the relationship between Arum and the primitive Lilytype be admitted, we have still to decide which of the two is the older. Does the line of descent start from the motherform of the Lily family and end in such genera as Arum and Arisaema, or do these represent a type earlier than that of the Lilies?

The succession suggested by the structure of their seedlings is from Anemarrhena, through forms perhaps resembling Chlorogalum and Arthropodium, to others like Allium and Zygadenus; thence to Anthurium. We may hope that future research will fill up the gap between Anthurium and Arum. Should it do so, would it be possible to read the chain backwards with equal probability?

If we make the attempt, we must suppose the point at which Anthurium approaches the Liliaceae to be that of greatest antiquity. A form resembling Zygadenus in the structure of its seedling must be accepted as the primitive type of that family. But the comparative study of seedling forms within the Liliaceae has shown that types of vascular symmetry differing so widely from each other as those of Eremurus, Zygademus, and Eucomis can all be referred to a single scheme -that which I have called type 4 (Diagram VI, p. 26). It is incredible that these genera should possess three distinct types of vascular structure in their seedlings, each of which should be modified through three distinct lines of descent until they all reached the same well-marked form-a form, moreover, which then appears in two genera such as Anemarrhena and Albuca, which have been always placed in separate tribes owing to the difference in their mature characters. 
These considerations lead to the conclusion that Anthurium must be held a more primitive type than Arum or Arisaema.

\section{Palmae.}

A number of young Palm seedlings were included in the Kew collection, and of these I have examined nine species. In three of them my observations are very incomplete, owing partly to a want of material at the proper age, and partly to difficulties of manipulation. The vascular structure of young Palms has often to be worked out by hand sections only, as the woody tissues of the axis do not embed well in paraffin.

Good microtome series have, however, been cut through the hypocotyls of Desmoncus minor, Thrinax excelsa, Areca sapida, and Phoenix dactylifera, and hand sections have given goods results in two other species, Desmoncus sp. and Acanthophoenix crinita. I can give a fairly complete account of the vascular system in the seedlings of these six species, though even here the details are commonly obscured by the massive development of the plumular traces due to the comparatively advanced age of the seedlings.

The external characters of all the Palm seedlings I have seen are much modified from the ordinary monocotyledonous type by the arborescent habit of the family, and their internal structure is not less profoundly affected. The first leaves are developed early. Their tissues are hard and woody from the first, owing to the number of vascular bundles developed within them and the stiffening of those bundles by massive sclerenchymatous sheaths. The primary root is always pretty well developed, and is sometimes the main root for a long time (Thrinax excelsa, Chamaerops humilis). In other species it is soon surpassed in length and thickness by the first cauline root. The vascular system of the latter is commonly the direct prolongation of plumular traces, as that of the primary root is of cotyledonary traces.

The tip of the cotyledon is merely a sucking organ, which for many months after germination continues to supply the seedling with nourishment from the stores laid up in the 


\section{Sargant. - Theory of the Origin of Monocotyledons}

endosperm. The lower part of the cotyledon plays many parts, and is modified in shape and texture to suit the habit of the seedling.

In Thrinax excelsa the plumular axis is connected with the seed by the long and rather slender petiole of the cotyledon. This expands at the base into a tough membranous sheath which completely surrounds the axis at its insertion. The four cotyledonary bundles run downwards through the sheath, in the same direction as the plumular traces, but outside them. Just above the node these four bundles form the outermost of a series of concentric circles in which all the traces of the axis are arranged, and they are equidistant from each other. At the first node the traces from the cotyledon run inwardsfrom the four points of the compass, as it were. Four plumular traces alternate with them in the stele of the hypocotyl, and the remainder are inserted on one or other of the circle of eight traces. An octarch root-stele follows quite regularly, apparently according to Van Tieghem's type I, by branching of the xylem groups.

In Desmoncus sp., D. minor, Areca sapida, and Acanthophoenix crinita, the cotyledon has a short petiole and a thick fleshy, sheath which is continuous with the primary root. The plumule is inclined to the cotyledon-sometimes almost at a right angle-and its traces are commonly continued downwards into one or more cauline roots, which penetrate the fleshy tissue of the cotyledonary sheath.

The apex of the cotyledon in the four species we are considering contains from ten to twelve bundles, irregularly disposed in a circle and without any trace of a midrib. Near the base of the petiole these become reduced to four by fusion with each other. In the sheath they approach each other in pairs, and when the plumular traces appear in the section the cotyledonary traces have united to form two massive bundles facing each other.

Sections which cut the cotyledonary traces transversely must of course pass through the plumular traces obliquely, and this distinction enables us to follow the course of the 
cotyledonary traces into the root-stele. They are always accompanied by two or three plumular traces, and they enter the stele from opposite sides. Thus the two groups of cotyledonary elements in the xylem of the root-stele are separated from each other by two or more groups of plumular elements. The root is often tetrarch or pentarch : sometimes hexarch or heptarch. The details of transition are never quite clear, but the process follows Van Tieghem's type I. In Desmoncus sp. the root, which is tetrarch when first formed, becomes octarch lower down.

The habit of the seedling of Phoenix dactylifera is very distinct from that of any of the Palm seedlings just described. The bundles of the inflated cotyledonary sheath form a circle of about ten, which are all continued into the primary root. The plumular traces are of course internal to this circle from the beginning. They are inserted on the cotyledonary traces without affecting the symmetry of the primary root-stele. The transition to a root-structure takes place by the branching of the xylem (Van Tieghem's type I), and the root is commonly io-arch.

The absence of a midrib in the cotyledon of the Palms is conspicuous not only in all the seedlings described, but also in two others which I have partly examined, Geonoma oxycarpa and Chamaerops humilis. But it should be added that the foliage leaves do not always possess a midrib, and that when present it is little distinguished from the others.

The adaptations to an arborescent habit are so well marked in all the species that the presumption is certainly against the primitive character of any particular feature. I may, however, mention that the well-grown cotyledon of Chamaerops humilis when extracted from the seed is seen to have a bifid apex. I remarked on this in my notes before the theory of a compound cotyledon had occurred to me, and compared it to the two lobes of a brain. The cotyledon of Ch. Fortunei is still more completely bilobed. This may very possibly be an adaptive character, but I should be glad to know whether it occurs generally among large-seeded Palms. 
On the whole the point to which I attach most importance is the gathering-up of the cotyledonary bundles into two groups which occurs in four out of the six species I have examined with care. Of the three species partially examined Euterpe edulis appears to resemble Thrinax, but the whole process is obscure. The cotyledonary traces have not been followed into the hypocotyl in Geonoma and Chamaerops.

Thus in four species out of seven there is a twofold symmetry in the traces of the cotyledon within the transitional region. In two more the symmetry is fourfold. The seventh, Phoenix dactylifera, shows an exceptional vascular symmetry corresponding with the exceptional habit of the whole seedling.

\section{Scitamineae.}

Five species from five different genera of this family have been worked out by Miss Thomas with success. They fall naturally into two groups.

The species of Musa and Canna are large and generally fleshy plants. Their seedlings resemble those of arborescent or shrubby genera, and their vascular symmetry corresponds to this habit. A number of massive bundles are found in the cotyledon. They are continued downwards into the hypocotyl, and with the assistance of plumular traces they form a polyarch root-stele.

The seedlings of Amomum, Elettaria, and Renealmia are of a different character, less fleshy, and rather of the herbaceous than the shrubby type. The three species examined in detail are Amomum angustifolium, Elettaria cardamomum, and Renealmia racemosa. Their vascular symmetry is strikingly similar.

The apex of the cotyledon remains permanently in the seed. It contains two bundles which there appear equivalent. They run the whole length of the petiole and sheath. But in the upper part of the sheath they are not symmetrically placed with regard to its outline. One occupies the position of a midrib, while the other might be taken for a lateral bundle without a pendant on the other side. This want of 
symmetry is probably due to mechanical causes. The seed is connected with the main axis by the long slender petiole of the cotyledon, and this enters the rather complicated cotyledonary sheath at an acute angle. The two bundles are so placed as to give strength and elasticity to the junction.

In all three species there is a fairly long hypocotyl; that is, the plumular traces join those from the cotyledon some distance above the level at which the stele becomes completely root-like. The cotyledonary traces are placed opposite each other in the sheath just above the first node, and in this region they seem perfectly equivalent.

The traces of the cotyledon enter the hypocotyledonary stele from opposite sides, and are separated by two plumular traces. The other bundles of the plumule are inserted on one or other of these four traces at the first node.

The fourfold stele below the first node has a very characteristic appearance. Each of the four xylem-masses is crescentshaped, and each group of phloëm is placed in the concavity of a crescent. As the eight horns of the xylem crescents reach the pericycle and form four pairs of xylem rays alternating with four phloëm groups, we seem at first to be looking at a tetrarch root. Closer inspection shows that the centre of the stele is occupied by a single group of protoxylem formed by the union of four internal groups. From this centre radiate four narrow rays of parenchymatous tissue dividing the four xylem crescents from each other.

Before the protoxylem becomes external a number of cauline roots are given off from the stele almost simultaneously. There are commonly four of these, and each is placed opposite one of the parenchymatous rays.

The primary root is tetrarch in Renealmia racemosa and Elettaria cardamomum. In the only complete series cut from Amomum angustifolium the central stele vanishes after giving off four cauline roots simultaneously. There would seem to be no primary root at all. This may be an individual peculiarity, or the primary root may be present but inclined at such an angle as to be mistaken for a cauline root. 


\section{Sargant.-Theory of the Origin of Monocotyledons}

There are points in this structure which recall that of Thrinax. The most important feature is, I think, the presence of two equivalent bundles in the cotyledon.

The twenty-five species of Monocotyledons-exclusive of the Liliaceae-which have just been described, fall naturally into two groups. The anatomy of seedlings belonging to the Amaryllidaceae, Iridaceae, and Aroideae seems to be derived from a Liliaceous type. That of the Palmae and Scitamineae is distinct in character, but the dual symmetry of the cotyledon is not less marked. The evidence from these two families, so far as it goes, is perfectly consistent with the hypothesis of a double cotyledonary member, and even gives it some support.

\section{PART II. RANUNCUlaceae.}

No detailed comparative study of this family has been attempted. The seedling which first attracted my attention was that of Eranthis hiemalis as described by M. Sterckx (38), to whose excellent monograph I have referred elsewhere. Since repeating his observations on the vascular system of Eranthis with particular reference to the tuberous hypocotyl, I have examined the seedlings of two other species possessing cotyledonary tubes: Delphinium $s p$. (possibly $D$. nudicaule) and Anemone coronaria, and also two species with distinct epigaeic cotyledons, Delphinium Requienii and Nigella damascena.

M. Sterckx has shown that the single cotyledonary member of Ranunculus Ficaria is in all probability formed by the union of two cotyledons by one margin only. I have repeated his observations on the external features of this seedling, and have made a careful study of the course of the vascular bundles in the cotyledon, hypocotyl, and primary root. For comparison two other species which show apparent lateral insertion of the cotyledons were chosen, Ramunculus Chius with epigaeic, and Anemone nemorosa with hypogaeic cotyledons. 


\section{founded on the Structure of their Seedlings. 53}

Eight species in all, representing five genera, have been examined, and will now be described in more or less detail.

The seedling of Nigella damascena has been chosen as the type of vascular structure in this family by MM. Gérard (13), Dangeard (9), and Sterckx (38). There is nothing to add to their account of the anatomy of the hypocotyl in this species. An outline of it will be sufficient here. The vascular symmetry agrees in all essentials with that of Delphinium Requienii, and Diagram IX represents the transition from a stem to a root structure within the hypocotyl of both species.

The three main bundles of the blade enter the petiole of each cotyledon, but soon unite to form a single massive bundle. This is particularly clear in Delphinium Requienii because, owing to the greater length of the petioles in this species, the union of the lateral bundles with the midrib takes place at some distance above the insertion of the cotyledons on the axis. At the level where it is joined by the lateral bundles the midrib is still to all appearance single.

Near the base of the petiole, the single massive bundle of each cotyledon opens out into a double structure precisely similar to that formed by each cotyledonary trace in Anemarrhena (Diagram VI). Both in Nigella and Delphinium however the double character of each bundle is very clear a short distance above the insertion of the cotyledonary traces on the plumular stele. M. Dangeard is so much struck by this feature in the cotyledon of Nigella that he does not hesitate to describe its petiole as containing two bundles $(9$, p. 85$)$. In this interpretation of the structure I entirely agree: the vascular symmetry of this genus and those which resemble it is much simplified by supposing four cotyledonary traces to enter the root-stele. A similar assumption has already been made with regard to the two traces of the cotyledon in Anemarrhena (p. 6).

The resemblance between the vascular symmetry of Delphinium or Nigella and that of Anemarrhena is obscured at the first node from a very simple cause. The traces of the 


\section{Sargant.-Theory of the Origin of Monocotyledons}

plumular stele are much more numerous and better differentiated in the Ranunculaceous seedlings examined than in seedlings of Anemarrhena which have reached the same stage of development. In Anemarrhena the plumule lags far behind the cotyledon. Moreover, among Dicotyledons a cambium is very well developed in the traces of both. Its position is indicated by the waved line in Diagram IX.

The stele of the hypocotyl is elliptical in Delphinium and Nigella. The two groups of cotyledonary xylem are placed at the extremities of the major axis, while two of the four phloëm masses fuse with each cluster of plumular phloëm

A

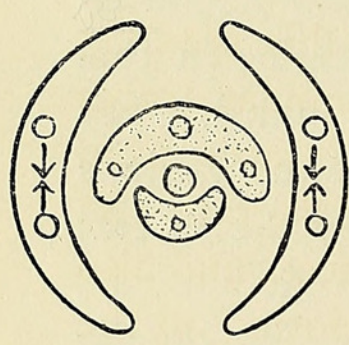

B

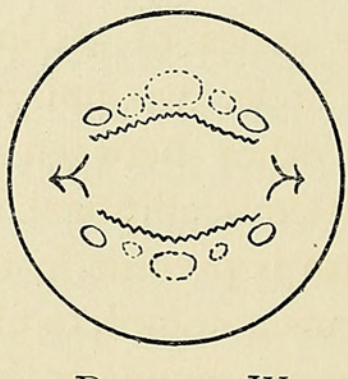

DIAGRAM IX.
C

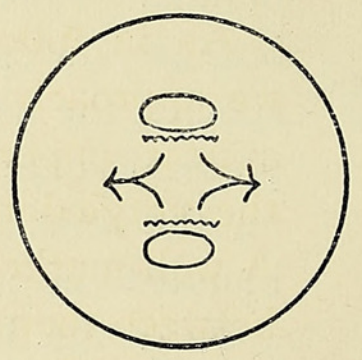

groups ( $\mathrm{B}$, Diagram IX). The root-stele becomes diarch at once. A considerable part of the metaxylem, as well as much of both phloëm groups, is derived from plumular traces.

These changes take place in the upper part of the elongated hypocotyl, and are commonly complete a few millimetres below the first node.

Several species of Delphinium have the petioles of their cotyledons united into a tube, and I have made a complete examination of one such species, probably $D$. nudicaule. The first leaves of this species are developed in the summer after germination, and they soon burst out of the sheath formed by the base of the united cotyledons (Lubbock, 30, vol. i. p. 97).

The cylinder formed by the united cotyledons is solid 
for about two-thirds of its length downwards from the insertion of the blades. In the lower part there is a small central cavity, not very clearly defined in transverse section, which gradually opens out as it descends, and so forms the conical chamber enclosing the stem-bud.

Two opposite bundles, one from each cotyledon, run the whole length of the cylinder, and each remains single until it reaches the level of the plumular growing-point. Here both begin to open out into a double structure. The activity of the cambium within them is already marked: at this level in a seedling so young that the first leaf is a mere rudiment in which the midrib is just indicated, two rows of radial unlignified xylem elements are found in each trace inside the cambial zone.

As in following the series of sections from this seedling we approach the first node, two unlignified plumular traces appear opposite each other between the two traces from the cotyledon. The stele is elliptical as in B, Diagram IX. A well-marked cambium is present in all the traces, and also between them. It forms a complete ellipse enclosing all the xylem. The formation of secondary tissue has already begun within the traces, where we find two or more rows of unlignified xylem elements outside the primary xylem which is also as yet unlignified.

The formation of secondary tissue reaches its maximum a little lower down, where in this young seedling the primary elements belonging to the plumular traces have almost disappeared. The four cotyledonary phloëm groups are approaching each other in pairs. They are separated from the well-lignified primary xylem of the cotyledon by a considerable bulk of secondary tissue. The secondary formations are best developed in those segments of the ellipse which were occupied by plumular traces : they are thinnest outside the two groups of cotyledonary xylem, in which the protoxylem is already external.

The diarch root-stele is formed as in Diagram IX. The activity of the cambium decreases in the lower region of 


\section{Sargant.-Theory of the Origin of Monocotyledons}

the hypocotyl, but a true cambial zone is still found in the upper part of the root.

The vascular symmetry of this species is practically identical with that figured in Diagram IX as the normal Ranunculaceous type. The only peculiarity which deserves notice is the precocious development of a cambium, and its extraordinary activity. This suggests that the growth of the hypocotyl into a spindle-shaped tuber, which is well marked at the end of the season, may be due to tissues added by the action of a normal cambium-ring. If so, the mature tuber may resemble that of Corydalis solida (Jost, 28).

The seedlings examined of Anemone coronaria are all much older than those of Delphinium sp., whose structure has just been described. The vascular symmetry of their cotyledon, hypocotyl, and primary root is however identical with that of Delphinium sp. Much more secondary tissue is present, and the stele has become circular owing to the greater activity of the cambium opposite the plumular traces. The secondary tissues are continued downwards far below the level at which the stele has become root-like. At no level have I found lignified secondary tissue outside the two protoxylem groups of the central plate of primary xylem, but radial rows of five or six well-lignified elements are found on the outer side of the plumular metaxylem, forming buttresses as it were to the central xylem plate. The two phloëm groups of the original diarch root-stele can still be identified, but they are isolated between the secondary tissues and the pericycle at a considerable distance from the centre of the section.

The growth of Eranthis hiemalis from the seed has been followed by Irmisch with his usual care (24). Nothing can be added to his account of the external characters, but for convenience I will briefly describe a first-year seedling (Pl. VI, Fig. I). The cotyledonary tube is very long, and the lower part is buried in the soil. Its base is inserted on a small tuber, which is spindle-shaped when first formed but later becomes globular. The plumule is quite rudimentary at this age: it is seated on the tuber and enclosed within the 
conical sheath formed by the base of the cotyledonary tube. The lower part of the tuber tapers off into the primary root.

Irmisch describes the cotyledonary tube as hollow throughout, and speaks of the cavity enclosing the plumule as in communication with the outer air through the narrow tunnel which opens between the blades of the cotyledons (24, p. $22 \mathrm{I}$ ). In the series of sections cut by the microtome through the tuber and adjacent parts of three young seedlings, however, I find a diaphragm of thin-walled tissue above the extinguisher-shaped sheath which encloses the plumule. The narrow bore of the tube itself is far less well outlined in transverse section than the plumular cavity, and is separated from it by the diaphragm just described. So far as can be determined from a number of hand-sections at different levels through the cotyledonary tube, it is hollow throughout, but one or more diaphragms may quite possibly exist above that which seals the plumular cavity. As the tuber increases in girth and the plumule in size, the base of the cotyledonary sheath is distended, and cracks appear in the diaphragm. These fissures may connect the cavities separated by the diaphragm, but only towards the end of the season when the cotyledons are withering.

No part of the plumule appears above ground until the second season after germination, but at the end of the first summer it is no longer embryonic. The first foliage leaf is then completely formed and ready to push upwards on the approach of spring (Irmisch, 24, Fig. I 5).

The massive bundles run the whole length of the cotyledonary tube and are continued into the tuber (Irmisch).

Any one of my three series of transverse sections through the tuber shows that it is simply the hypocotyl, swollen by the development of the cortex and conjunctive tissue into a storehouse for starch and other food-material. The vascular system of the first-year tuber is derived exclusively from the cotyledonary traces, for during the time that this system is developed the plumule is still so embryonic that the position of its procambial strands is not even indicated. The process 


\section{Sargant.-Theory of the Origin of Monocotyledons}

of tuber-formation in this species is thus quite distinct from that described in Delphinium sp. and Anemone coronaria. The increase of girth was there due to the formation of secondary tissue by a normal cambium, and the plumular traces took a large share in the formation of its vascular system.

The behaviour of the cotyledonary traces when they enter the axis is indicated in Diagram X and very fully illustrated on Plates VI and VII.

The sections drawn in Figs. 2-6 of Pl. VI and Figs. I and 2 of Pl. VII are from a single series cut through the tuber of
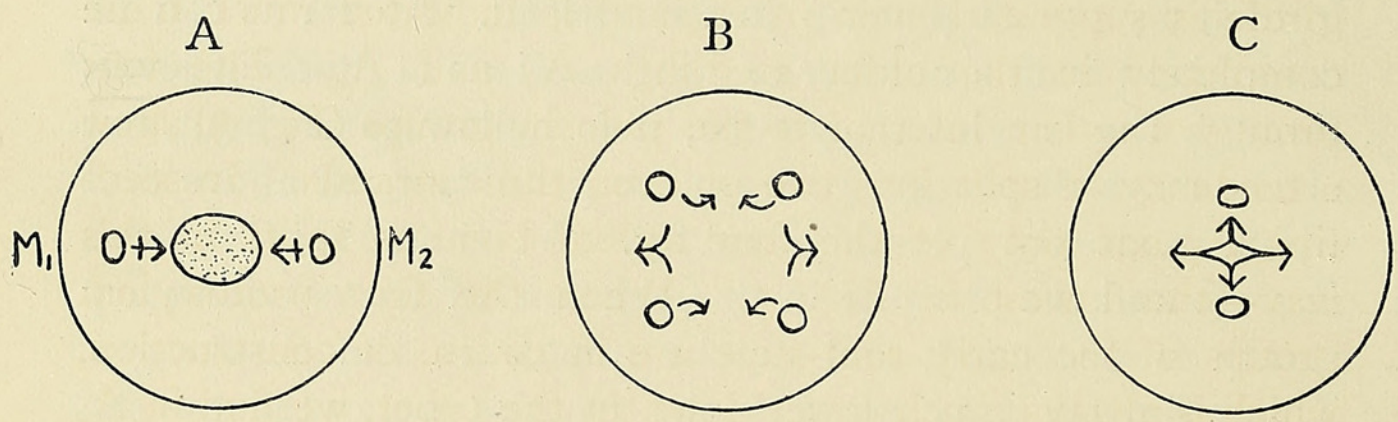

Diagram X.

a seedling younger than that outlined in Fig. I, Pl. VI. The bundles of the cotyledon show traces of double structure even before they leave the cotyledonary tube. There are traces of cambium between the phloëm and xylem of each (P1. VI, Fig. 3). The compound nature of the traces becomes more clearly evident as they enter the tuber. A little lower down the phloëm groups of each pair have drawn further apart, and the xylem elements are in three clusters : one internal to either group of phloëm and one solitary between the other two (Fig. 4). This intermediate cluster then breaks up into two parts, and we have eight xylem and four phloëm groups arranged symmetrically in two parallel straight lines, each of which is equidistant from the periphery of the section and its centre (Fig. 5).

Down to this level the three complete series of sections 
which I have compared with each other agree in every detail. They are cut from three seedlings, of which $A_{6}$, that outlined in Fig. I (Pl. VI), is the oldest, and $A_{2}$, from which Figs. 2-6 are drawn, is the youngest. The intermediate seedling $A_{5}$ is nearly as old as $A_{6}$. The course of the bundles in the region intermediate between Fig. 5, Pl. VI and Fig. I on Pl. VII is indicated in $B, D i a g r a m ~ X$. The details of the process differ slightly in the three seedlings cut.

In all three the traces keep to a zone which lies about halfway between the periphery and the centre of the tuber, and their course downwards follows its outline, first curving outwards and then closing in again. The formation of a phloëm girdle is suggested even in $A_{2}$, and is indicated much more completely in the older seedlings $A_{5}$ and $A_{6}$. The four groups of xylem internal to the phloëm groups (Fig. 5) show a tendency to split into two or even three strands. In seedling $A_{2}$ one only of the four xylem bundles splits in this way - the lowest in Fig. 5. When the four protoxylem groups of the early root-stele are in course of construction, which is always much lower down in the tuber, we find in $A_{2}$ that the xylem group in the lower left-hand corner of the section is being built up of three strands instead of two (Fig. 6). Moreover, an offshoot from the aberrant group of xylem has already ended blindly.

The four corresponding xylem groups of seedlings $A_{5}$ and $A_{6}$ commonly split into two or more strands. To follow each minute cluster of xylem elements through a series of sections cut from a comparatively massive tuber is a task requiring some patience. I have done so in these three seedlings, and have convinced myself that the result may be fairly represented by the generalized Figure B in Diagram X. The strands from each original group commonly unite again lower down : anastomoses with adjacent groups do occur, but are exceptional. The whole process is clearly an adaptation to the needs of the tuber. I suspected at first that a complete xylem network was indicated with which the first cauline roots would later be connected, but a series of sections 
cut through a second-year tuber by Miss Thomas shows that no regular network exists there. The xylem strands are better developed than in the first-year tuber, but travel downwards in the same isolated way. Where a cauline root is given off, the xylem strands in the immediate neighbourhood collect together and anastomose.

The irregularities in the vascular system of first-year tubers affect the four xylem strands only which are in the neighbcurhood of phloëm groups, and do not extend to the two pairs of slender xylem strands between them $\left(x_{m}, x_{m}\right.$, in Fig. 5, Pl. VI). Their behaviour is remarkably uniform in all three seedlings. Each pair is derived, as has been shown, from a single xylem strand, and the two halves reunite about halfway down the tuber, or even earlier. The two xylem groups thus formed on opposite sides of the tuber preserve their identity, and are continued downwards into the root, where they form the two permanent protoxylem groups of the root-stele. It is exceedingly rare to find any connexion between these xylem groups and the other strands scattered round the tuber.

These scattered strands draw together in two groups, phloëm and xylem alike, and form two bundles facing each other. Fig. 6 on Pl. VI shows the orientation of such a stele in process of formation. To right and left are clusters of xylem elements unaccompanied by phloëm, and with the protoxylem elements already external. To the north-east of the stele, as it were, is a slender bundle having an external phloëm group, three lignified elements within it representing the primary xylem, and two radial rows of two unlignified elements each to represent the secondary formation. A similar group is in course of formation on the opposite side.

At the base of the tuber the stele closes round the centre of the section, and a tetrarch xylem plate is formed. Two phloëm groups only are present, and these are placed outside the two lateral protoxylem rays $\left(p x^{\prime}, p x^{\prime}\right.$, in Figs. I and 3 on Pl. VII). The outermost elements of these rays can be traced backwards and identified as part of the primary forma- 


\section{founded on the Structure of their Seedlings. 6I}

tion in the bundles of the tuber. There are often two or three unlignified secondary elements in rows outside them (Pl. VII, Fig. 3).

The two protoxylem groups which are flanked by phloëm shortly die out, and the root is left with a diarch stele (Pl. VII, Fig. 2).

The vascular symmetry of Eranthis hiemalis has already been compared with that of Anemarrhena (pp. 4 and 5, and Sargant, 35, P1. 2). The resemblance is clear from Diagrams VI and X. I will not go over the ground again. But some remarks may be offered on the difference between these types.

The formation of a diarch root-stele in the typical Ranunculaceous seedling is clearly connected with the insertion of a vigorous plumular stele on the comparatively insignificant cotyledonary traces, and the continuation of both into the persistent primary root (cf. Diagram IX). In plumule and root alike, secondary thickening is early developed and plays an important part. They are connected largely by means of secondary xylem, while the primary xylem of the cotyledon is continued downwards into that of the primary root. We may conceive a remote ancestor of the Ranunculaceae to have possessed four cotyledonary traces which regularly formed a tetrarch primary root by branching of the xylem according to Van Tieghem's type I, and that its comparatively slender plumular traces were inserted on two opposite traces of the hypocotyledonary stele. Then if the plumule began to increase in importance and develop earlier, its traces would exercise an increasing influence on the stele of the hypocotyl. The plumular phloëm would by degrees unite with the adjacent cotyledonary groups, and thus form a single huge mass on either side of the stele. The secondary formations produced by the action of plumular cambium between each mass of phloëm and the cotyledonary xylem within it would in time arrest the development of the latter, and perhaps suppress it altogether. Finally, the root-stele would become completely diarch. The vascular systems of Albuca (p. 9), Chlorogahum, Anthericum, and Anthropodium (p. 30) 
show how readily a tetrarch root-stele may become diarch by suppression of opposite protoxylem rays.

The hypothetical vascular system at which we have now arrived corresponds very closely to the Ranunculaceous type (Diagram IX). In this two cotyledonary traces only enter the hypocotyl, but they give very clear evidence of their double origin, as M. Dangeard has already remarked (9). In every other respect the schemes are identical.

Returning to the hypothetical Dicotyledon, whose seedling has a fourfold symmetry throughout its vascular system, let us suppose the c'evelopment of the plumule to be arrested rather than accelerated, and secondary thickening to disappear altogether from the axis. This development of the vascular scheme leads to a symmetry closely resembling that of Anemarrhena. The latter indeed possesses but two cotyledonary traces, but each gives very clear indications of its double origin when it enters the hypocotyl.

To derive the vascular system of Eranthis hiemalis from our four-partite ancestor, we must suppose the plumule to have increased in importance up to a point at which the tetrarch symmetry of the root has almost disappeared. The whole vascular system was developing on Ranunculaceous lines. But at this point the ancestor of Eranthis parted company with its fellows. The plant perhaps had to adapt itself to different climatic conditions. These postponed the development of the plumule, and led to the formation of a tuber from the hypocotyl by the increase in mass of cortex and conjunctive tissue. This process gradually put a stop to secondary thickening by isolation of the bundles within the tuber, and the vascular system became what we see it in Evanthis.

Little weight can be attached to hypothetical genealogies of this kind. They are valuable only as suggesting lines of research. In this case the investigation of forms allied to Anemarrhena on the one hand and to Eranthis on the other may yield valuable results. The seedlings of other species of Eranthis are, I believe, still undescribed even in their external characters. Their vascular structure is entirely unknown. 
founded on the Structure of their Seedlings. 63

The homology of the single seed-leaf of Ranunculus Ficaria (Pl. VII, Fig. 4) has been much discussed. The reasons given by M. Sterckx (38, p. 43) for considering it a fusion of two cotyledons seem very strong.

He points out that the venation of the bifid blade suggests its double origin. I have repeated his observations (Fig. 5) and agree in this conclusion. The blade is folded in the seed, and retains a well-marked median crease which is easily mistaken for the midrib in fresh material. But when the blade is blanched by immersion in methylated spirit, and has then been made transparent by treatment with phenol, the course of the veins can be accurately followed. Two main veins traverse the two segments of the blade respectively. Branches from both of these run upwards near the median crease, and when such branches unite with each other they sometimes appear to form a true midrib ( $B_{1}$, Fig. 5). In other specimens its absence is clear $\left(A_{3}\right.$ and $A_{4}$, Fig. 5).

The formation and maturation of the embryo within the seed has been followed and described with great care by M. Sterckx (38, p. 42, and Figs. I5I-9). The embryo in the ripe seed is very small. It is spherical, quite undifferentiated, and attached to a short suspensor. The cotyledonary member is lateral throughout its development. It is distinctly bilobed by the end of the summer in which the seed is sown. Throughout the following summer the development of the embryo continues within the seed. It germinates in the second spring, nearly two years after the seed was ripened.

The 'cotyledon' comes above ground at once on germination, and acts as the first assimilating organ. Its petiole is in a straight line with the hypocotyl and primary root. The lower limit of the hypocotyl is rather sharply defined externally by the sudden decrease in diameter of the axis where the primary root begins, but the upper limit cannot be determined until the position of the plumule is ascertained. It first appears as a slight swelling at the base of the cotyledon. Sometimes the first cauline root, always formed immediately below the plumule, shows first as a little tooth pointing 
downwards (Fig. 4, Pl. VII). The length of the hypocotyl defined by its external characters varies from $5 \mathrm{~mm}$. to I $\mathrm{mm}$., or even less in the seedlings I have examined.

The external features of this seedling have been so fully described by Irmisch (21, p. I) and Sterckx (1. c.) that I may go on at once to its vascular structure. The three seedlings $A_{3}, A_{4}$, and $B_{1}$, from which $I$ have cut complete series of sections, agree with each other in every detail. That figured on P1. VII is the youngest of the three.

A single massive bundle runs down the whole length of the cotyledonary petiole. It is enclosed in a well-defined endodermis and contains a normal cambium layer. The phloëm is a compact rounded strand, and there is a single protoxylem group, but the elements of the metaxylem form two distinct clusters separated by a few thin-walled cells. At the base of the cotyledon the petiole is bordered by two membranous wings which are united round the embryonic bud of the plumule into a closed sheath. At this level the cotyledonary trace has opened out slightly: the phloëm mass is divided as well as the metaxylem. A single plumular trace joins it at the first node (Figs. 6 and 7). As they meet, the plumular trace becomes double and opens out in the same way as that from the cotyledon (Fig. 7). Very little below this both groups of protoxylem have become external, and a diarch root is constituted (Fig. 8). The process of transition recalls that found in Zygadenus.

The length of the hypocotyl defined by its vascular characters does not exceed $.5 \mathrm{~mm}$. in any of the seedlings cut.

The lateral position of the cotyledonary member is clearly an advantage to the plant. It allows the foliage leaves to develop unchecked by the necessity of bursting through a tubular sheath, as they must do in Delphinium mudicaule and Anemone coronaria. The 'cotyledon' of Ranunculus Ficaria may possibly have been derived from a tubular fusion such as that found in these plants. R.parnassifolius possesses a long cotyledonary tube (Winkler, 44), and $R$. millefoliatus a shorter one (Irmisch, 26, p. 29). But it seems more likely that the 
founded on the Structure of their Seedlings. 65 two cotyledons from which the seed-leaf of $R$. Ficaria has been formed became united by one margin only from the first. M. Sterckx describes such a formation in Anemone apeninna (38, Figs. 76, 77). An abnormal seedling of Ramunculus repens in which the cotyledons are partly united by one margin is figured by Lord Avebury (Lubbock, 30, vol. i. p. 90). I have found the cotyledons of $R$. Chius to be so united in the only three seedlings I have seen, but in no case more than halfway up the petioles.

Sections through one such seedling of $R$. Chins show that the vascular structure is by no means unilateral at the base of the cotyledons. They are united into a shallow cup round the plumular bud, and a trace from each enters the short hypocotyl at opposite extremities of a diameter. The transition to a root-structure follows the usual Ranunculaceous type (Diagram IX)

The same is true of Anemone nemorosa, in which the hypogaeic cotyledons have a false appearance of being inserted laterally so long as they are held together by the seed-coats. The few diagrams given by M. Sterckx of the vascular structure in $A$. apennina suggest that it may possess characters really intermediate between the usual type and that of Ranunculus Ficaria.

\section{Part III. General Considerations on the Origin of Monocotyledons.}

In the first Part of this paper I have given a full abstract of my observations on the vascular symmetry of Monocotyledonous seedlings, and have attempted to show that the facts justify the following conclusions :-

The vascular symmetry characteristic of the seedling in the monotypic genus Anemarrhena represents a type which is comparatively primitive among the Liliaceae. For many types of seedling structure found within that family can be shown with great probability to be derived from it, and the other types described are either clearly much modified by their environment, or so isolated systematically from the rest 
of the seedlings examined that the absence of intermediate links is of little weight.

The Anemarrhena type of vascular structure is bisymmetrical throughout, and suggests a double origin for the cotyledonary members.

The vascular symmetry of the seedlings examined from other Monocotyledonous families can be either derived from a Liliaceous type, or shown to be equally bisymmetrical.

In the second Part I have described the vascular structure of a number of seedlings belonging to the Ranunculaceae which possess cotyledons more or less completely united to each other. When the united cotyledons are symmetrical with regard to the plumular axis-as in Eranthis hiemalis, Delphinium sp., and Anemone coronaria - their vascular structure is bisymmetrical, and that of Eranthis bears a close resemblance to the structure of Anemarrhena. When the cotyledonary member is unilateral, as in Ranunculus Ficaria, its vascular structure is asymmetrical with regard to the axis.

The strength of this comparison does not depend wholly on the suggestion of a real genetic relationship between Anemarrhena and Eranthis for example, though I am inclined to think such a relationship probable, but rather lies in the fact that a partial union between two cotyledons does actually give rise to a reduced vascular system which bears a strong likeness to that existing in Anemarrhena and Albuca, a system already shown on comparative grounds to be in all probability the original of other Monocotyledonous types.

The derivation of a seedling with unilateral vascular symmetry, such as that of Zygadenus elegans, from a symmetrical form like Anemarrhena, has been justified by the examination of vascular systems intermediate between these extremes. The actual genealogy of Zygadenus is still of course conjectural, but the a priori probability of such a descent is certainly increased by the analogy with Ranunculus Ficaria. The origin of the cotyledonary member in this species has already been fully discussed (p. 63). The conclusion there drawn from its external characters is that it has been formed 
founded on the Structure of their Seedlings. 67

by the union of two seed-leaves, which were distinct in a remote ancestor, and perhaps partially united in a more recent one. If this conclusion is justified, the vascular system of such ancestors would certainly be bilaterally symmetrical, and might probably resemble that of Eranthis. But in the seedling of $R$. Ficaria the vascular system of the cotyledon is unilateral in a very marked degree; quite as one-sided as that of Zygadenus, which indeed it closely resembles. We need not be startled then by the presence of a midrib in the cotyledon of Zygademus, nor by its lateral position with regard to the axis, since both characters are found in the seedling of Ranunculus Ficaria, together with independent evidence of the double origin of its cotyledon.

The observations condensed in the first two Parts of this paper have led me to the conclusion that the single seed-leaf of the Liliaceae and allied orders is a compound member formed from the two seed-leaves of a remote ancestor. If this be admitted, the probability is that the seed-leaf of all Monocotyledons has a similar origin, and my observations on the Palms and Scitamineae confirm this view so far as they go.

In the third and last Part of this paper I propose to discuss the whole theory of the origin of Monocotyledons which naturally arises from the view I have just expressed concerning the origin of their seed-leaf.

This discussion will raise three questions, which can be treated separately :-

I. The comparative antiquity of the Monocotyledons and Dicotyledons.

2. Assuming the superior antiquity of Dicotyledons, can the single seed-leaf of Monocotyledons have arisen otherwise than by the fusion of two cotyledons into one member?

3. Assuming the double origin of the seed-leaf in Monocotyledons, can we form any hypothesis as to the way in which the fusion first began, and concerning the correlation of this character with the others which distinguish Monocotyledons? 


\section{Comparative Antiquity of Monocotyledons and Dicotyledons.}

The Angiosperms form a very well-defined group, and modern research has tended to show that the gulf between them and the Gymnosperms is even wider than was formerly supposed. To borrow an expressive phrase, we have begun to realize the isolation of the Angiosperms.

Within this group the Monocotyledons are divided from the Dicotyledons by a number of natural characters, but these two classes are undoubtedly far more closely related to each other than is either of them to any other group of plants. The presumption is strong that they come from a common stock.

A generation ago the Monocotyledons were regarded as probably the older group, but botanists have never been unanimous in this opinion, and of late the evidence of fossil botany has on the whole inclined the scale in the opposite direction. The case is so admirably summed up by Professor Bayley Balfour (in the article on Angiosperms, Supplement to Encyclopedia Britannica, vol. xxv, I902), that I am tempted to quote his judgement in full :-

'The position of Angiosperms as the highest plant-group is unassailable. ....We readily recognize in them now-adays the natural classes of Dicotyledones and Monocotyledones, distinguished alike in vegetative and in reproductive construction, yet showing remarkable parallel sequences in development; and we see that the Dicotyledones are the more advanced and show the greater capacity for further progressive evolution. But there is no sound basis for the assumption that the Dicotyledones are derived from Monocotyledones; indeed the palaeontological evidence seems to point to the Dicotyledones being the older. This however does not entitle us to assume the origin of Monocotyledones from Dicotyledones, although there is manifestly a temptation to connect helobic forms of the former with ranal ones of the 


\section{founded on the Structure of their Seedlings. 69}

latter. There is no doubt that the phylum of Angiosperms has not sprung from that of Gymnosperms.'

The question so far then is open, and there is nothing in the present state of botanical knowledge to discredit the conclusions which I have drawn from embryological evidence because they infer the superior antiquity of the seedling with two cotyledons.

The development of the embryo within the seed has sometimes been thought to show that the seed-leaf of Monocotyledons is a terminal member, and its plumule lateral. If this conclusion were well founded, it would be difficult to derive the Monocotyledonous embryo from a Dicotyledonous form. We should be almost forced to consider the one-leaved form as the more ancient. The two seed-leaves of a Dicotyledonous embryo must then be derived from the splitting of the original terminal member.

But the comparative work of Hegelmaier (14) and others has shown how little phylogenetic importance can be attached to details of structure in the embryo at this early age. In Corydalis ochroleuca, for example, there is a slight but undoubted cleft in the embryo of the ripe seed which separates the cotyledons from each other, while in C.cava no such division exists. The embryo is Monocotyledonous from the first.

The change from a Dicotyledonous to a Monocotyledonous habit must have taken place at a comparatively recent period in this case : more recent, that is, than the origin of Corydalis as a genus. Yet we know from the researches of Dr. Schmid ${ }^{1}$ that no traces of the original bicotyledonary structure are to be found in the early history of the embryo of Corydalis cava.

The very careful observations of M. Sterckx (38, p. 42) on the embryo of Ranunculus Ficaria up to the period of germination illustrate the same point. I have already referred to them (p. 63), and will only say here that the history of the embryo within the seed throws little light on the homology of the single cotyledonary member. Nothing in its develop-

1 Schmid, Beiträge zur Embryo-Entwickelung einiger Dicotylen. Bot. Zeit. 1902. Abth. I. p. $20 \%$. 
ment contradicts the theory of its double origin, but I doubt whether that origin would have been suggested by the structure of the embryo at any period had the union of the cotyledons in the mature organ been more perfect.

Finally, Count Solms-Laubach (37) has shown that the cotyledon is not always apparently terminal in the embryo of Monocotyledons. In several genera belonging to the Commelinaceae, and in Tamus communis, the plumule is terminal from the moment of its appearance, and the single seed-leaf lateral. Its development in these species resembles that of the cotyledonary member in Ranunculus Ficaria.

These considerations are sufficient to throw doubt on the theoretical conclusions drawn by Mr. H. L. Lyon (31) from his interesting observations on the development of the embryo in a single species of Nelumbium. Professor Strasburger $(39, \mathrm{p} .5 \mathrm{IO})$ has pointed out that the apparently lateral position of the growing-point described by Mr. Lyon in this species is probably due to the position of the embryo within the embryosac, and that the same cause might bring about the early fusion of both cotyledons into a single rudiment, though they are later quite distinct.

\section{Homology of the Seed-leaf in Monocotyledons.}

Assuming that the seedling with one seed-leaf is derived from an ancestor with two, the change may have come about in one of two ways. One cotyledon of the pair may have been suppressed by degrees, or both have united to form a single member.

The first alternative is that adopted by Mr. Henslow in 1892 (15). It has commonly been regarded as the only working hypothesis by the botanists who have seriously considered the possibility of deriving Monocotyledons from a Dicotyledonous stock.

When in IgO2 I published a short paper in the New Phytologist (35) giving an abstract of the reasons which led me to the conclusion that the single 'cotyledon' of Monocotyledons was derived from both the cotyledons of a remote 


\section{founded on the Structure of their Seedlings. 7I}

ancestor, I was not aware that this possibility had been suggested before. But a reference in Bernhardi's paper of 1832 (4, p. 584) has recently led me to consult Agardh's text-book (1, p. 197).

Agardh proposes to class the embryos of all flowering plants in four main groups, thus :-

Dicotyledones $\left\{\begin{array}{c}\text { Dicotyledones verae (all Dicotyledons except } \\ \text { Nymphaeaceae). } \\ \text { Polycotyledones (Coniferae). }\end{array}\right.$

Kryptocotyledones $\left\{\begin{array}{l}\text { Syncotyledones. } \\ \text { Monocotyledones (Gramineae). }\end{array}\right.$

Under Syncotyledones he includes Lilieae, Aroideae, Naiadeae, Palmae, Scitamineae (p. I97), and afterwards mentions as belonging to the same class, Cycades and Nymphaeaceae.

This classification was probably influenced by the fact that Agardh did not distinguish clearly between the endosperm and the cotyledon in the Monocotyledonous embryo, and still less in that of the Nymphaeaceae. He treats the embryo with two seed-leaves as the type, and considers that of the Syncotyledones to be derived from it by the fusion of the two original seed-leaves into a thick fleshy mass.

The Grasses are considered as the only true Monocotyledons because their seed-leaf has become single by the suppression of the second seed-leaf opposite to it. Thus Agardh derives the structure of the Grass-embryo also from a Dicotyledonous type.

It is remarkable that the Monocotyledonous families mentioned by Agardh as typical Syncotyledones (Lilieae, Naiadeae, Aroideae, Palmae, Scitamineae) are precisely those on which I have worked. His Lilieae probably include Irids and Amaryllids as well as the true Liliaceae. So far I have not examined any seedling from the Naiadeae, but with this exception we have the same horizon. I cannot therefore express any opinion as to the possibility of a distinct origin for the embryo of the Gramineae. It has been proposed 


\section{Sargant.-- Theory of the Origin of Monocotyledons}

in our own day to separate them from other Monocotyledons on embryological grounds (Van Tieghem, 44).

The structure of some Ranunculaceous seedlings in which the cotyledons are partially united has already been described at length. The similarity between their vascular symmetry and that of a type of seedling primitive among the Liliaceae has led me to a conception of the Monocotyledonous embryo nearly identical with that of Agardh. This comparison has already been emphasized, but it must not be supposed that such partial union of the seed-leaves is confined to the Ranunculaceae and their near allies. On the contrary, examples of such structure are recorded from many families, some widely separated systematically from the Ranunculaceae.

The seedlings in which partial fusion of two cotyledons occurs may be divided into two classes of very unequal size.

In the first, the cotyledons are united by both the margins of their petioles. These form a slender cylinder, which is not always hollow throughout its length. There is always a conical chamber at the base however, within which the plumular bud is developed.

In the second class, the petioles are united by one margin only. The double member thus formed is always lateral with respect to the plumular axis.

The formation of a cotyledonary tube in the first way has been recorded in a large number of species, but the literature of the subject is scattered. The following list makes no pretence to be exhaustive. I have included in it only those species of which I have seen figures, or descriptions sufficiently full to make the facts certain. The references are to such descriptions : in the choice of authorities I have preferred the more recent and more easily accessible, and have taken no account of priority in discovery. 
founded on the Structure of their Seedlings. 73

TABLE I.

Dicotyledonous seedlings with a well-marked cotyledonary tube.

Ranunculaceae.

Anemone coronaria - . Irmisch, 23, p. I (Fig.).

A. alpina : . . . Irmisch, 23, p. 6 (Fig.).

A. blanda . . . . Hildebrandt, 17, p. Io (Fig.).

A. narcissiflora . . . Hildebrandt, 17, p. 18.

A. rupicola . . . . Lubbock, 30, I, p. 85 .

Ranunculus parnassifolius Winkler, 44, p. I27.

Trollius Ledebouri * . Lubbock, 30, I, p. 9I (Fig.).

Eranthis hiemalis . . . Irmisch, 24, p. 22I (Fig.). Sterckx, 38, p. 5I (Fig.).

Delphinium nudicaule - Lubbock, 30, I, p. 97 (Fig.). Darwin, 10, p. 80. Sterckx, 38, p. 59 (Fig.).

D. hybridum (vars. puni- Bernhardi, 4, p. 574 . ceum, fissum, ochroleucum)

Aconitum Anthora . . Irmisch, 27, p. 365 (Fig.).

Berberidaceae.

Leontice vesicaria (= L. Bernhardi, 4, p. 577 (Fig.). Leontopetalon)

L. altaica (= Bongardia Bernhardi, 4, p. 577 . Rauwolfii)

Podophyllum peltatum. Holm, 19, p. 4I9 (Fig.).

P. Emodi . . . . Lubbock, 30, I, p. II4 (Fig.).

Cruciferae.

Dickson, 12 (Fig.).

Cardamine (species from Bernhardi, 4, p. 60I. section Dentaria)

Geraniaceae. Hildebrandt, 17 , pp. 22 and 33 (Fig.).

Oxalis (tuberous species, Hildebrandt, 16, Pl. V. as $O$. rubella and others) 
74 Sargant. - Theory of the Origin of Monocotyledons

Rhizophoreae.

Rhizophora Mangle . . Klebs, 29, p. 562.

Rh. conjugata . . . Kerner and Oliver, I, p. 602

Cucurbitaceae.

(Fig.).

Megarrhiza Californica, Darwin, 10, p. 8 I (Fig. 58).

Torr. (= Echinocystis Lubbock, 30, I, p. 597.

fabacea)

Umbelliferae.

Smyrnium perfoliatum . Lubbock, 30, II, p. 29 (Fig.).

S. rotundifolium . . L Lubbock, 30, II, p. 24.

S. Olusatrum . . . Lubbock, 30, II, p. 24. Holm, 20, p. 66.

Bunium luteum ( $=\mathrm{Mu}-$ Bernhardi, 4, p. 607 (Fig.). retia tanaicensis)

Chaerophyllum bulbo- Irmisch, 21, p. 22 (Fig.). sum

Prangos ferulacea . . Bernhardi, 4, p. 575 (Fig.).

Compositae.

Serratula radiata . . Winkler, 43, p. I37 (Fig.).

Primulaceae.

Dodecatheon Meadia . . Bernhardi,4,pp.573,578(Fig.).

Polygonaceae.

Polygonum bistorta . . Winkler, 43 (Fig.).

P. sphaerostachyum . . Lubbock, 30, II, p. 439.

Rheum Moorcroftianum Holm, 18.

This list, though doubtless incomplete, contains no case which is not well authenticated ${ }^{1}$, and I have purposely omitted from it those species which possess a cotyledonary tube wide in proportion to its length, even when the length is considerable. In such seedlings the plumule develops without diff-

1 The petioles of the cotyledons in Megarrhiza Californica are said to be apparently connate but really separable (Lubbock, 30, I, p. 597). This does not agree with the description of Asa Gray, quoted by Darwin (10, pp. 8I-3). 
culty within the cotyledonary tube, and their habit is not dissimilar from that of seedlings with distinct cotyledons.

Short petiolar tubes are not uncommon among the seedlings of species allied to those included in Table I. For example: Ranunculus millefoliatus (Irmisch, 26, p. 29, Fig. I), Ferula foetida (Lubbock, 30, II, p. 37), Serratula tinctoria (Winkler, 41) Cotula coronopifolia (Lubbock, 30, II, p. 134), and Rheum officinale (Lubbock, 30, II, p. 442, Fig. 622). They link the numerous species in which the cotyledons are merely connate at the base with those in which the cotyledonary tube is fully developed, and their existence is a strong argument for the derivation of such tubes from the fusion of two cotyledons, and not, as Professor D. H. Campbell has suggested ( 7, p. I I ), from the division of one.

From the first class of seedlings with united cotyledons we may now pass to the second. Ranunculus Ficaria and Anemone apennina (Sterckx, 38, pp. 34 and 80, Figs. 76, 77) are the only species with which I am acquainted in which the cotyledons are normally united by one margin only. Such unions are, however, not unfrequently found in abnormal specimens of species with distinct cotyledons. Ranunculus repens (Lubbock, 30, I, p. 90, Fig. 129) and $R$. Chius have been mentioned already. Irmisch found this abnormality in several seedlings of Phlomis tuberosa (22, p. 25, Fig. 105). Mrs. Stebbing has shown me a drawing of an abnormal seedling of Urtica dioica in which the blades as well as the short petioles of the two cotyledons are united by one margin.

No doubt such instances could be multiplied. Their interest lies in the possibility they suggest that the single seed-leaf of some species among those Dicotyledons which possess but one may be formed in a similar way.

The seed-leaf of Pinguicula vulgaris, for example, looks in Buchenau's figures (6, Figs. I and 2) as if it might be derived from the union of two cotyledons by one margin only. Dickson (11) states that $P$.grandiflora also germinates with a single seed-leaf, the blade of which is bifid. $P$. caudata and $P$. lusitanica have separate cotyledons. 


\section{Sargant. - Theory of the Origin of Monocotyledons}

The following list of the best-known pseudo-monocotyledons is no doubt very imperfect. The only species in it which I have examined is Cyclamen persicum. Its vascular structure suggests very strongly that the cotyledonary member consists of two seed-leaves united into a solid tube, but until the structure of allied genera has been worked out no great weight can be attached to this observation. Bernhardi (4, p. 578 ) suggests this origin of the single seed-leaf on the ground that the cotyledons of Dodecatheon Meadia are united into a tube. Lord Avebury remarks that when Cyclamen is raised from seed abnormal specimens are not uncommon in which the cotyledons have divided blades (Lubbock, 30, II, p. I84).

\section{TABLE II.}

\section{Pseudo-monocotyledons.}

Fumariaceae.

Corydalis tuberosa, D.C. (= Irmisch, 25 (Fig.).

C. solida and C. cava) . . Bischoff, 5 (Fig.).

C. fabacea . . . . . . Irmisch, 25 (Fig.).

Dicentra Cucullaria, Bernh. Irmisch, 25.

(= Capnorchis Cucullaria)

\section{Umbelliferae.}

Carum Bulbocastanum . . Irmisch, 21, p. 17 (Fig.).

C. alpinum, Benth. and Hook. Bernhardi, 4, p. 575 .

(= Bunium petraeum, Ten.)

Erigenia bulbosa, Nutt . Holm, 20, p. 63 .

Primulaceae.

Cyclamen persicum . . Darwin, 10, p. 78(Fig. 57). Lubbock, 30, II, p. 184 . Bernhardi, 4, p. $5^{8} 3$.

Lentibularieae.

Pinguicula vulgaris . . . Buchenau, 6, p. 64 (Figs. I and 2).

Dickson, 11.

P. grandiflora . . . . Dickson, 11. 
Nyctagineae.

Abronia umbellata . . D Darwin, 10, p.95(Fig.6I).

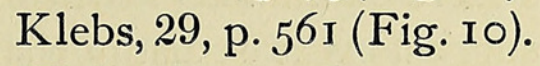

A. arenaria . . . . Klebs, 29, p. 560.

A. grandiflora . . . . Klebs, 29, p. 560.

The existence of some Dicotyledons with only one seedleaf is commonly explained by the supposition that one seed-leaf of the pair is abortive. This may be so in some of the species in the foregoing list, as Abronia umbellata (see Darwin, 10, p. 95): other cases may arise through the fusion of cotyledons by one or both margins.

\section{Origin of the Monocotyledonous Habit.}

If the homology of the single seed-leaf in Monocotyledons with both the seed-leaves of Dicotyledons be accepted as a working hypothesis, we are at once confronted with another question. How did that fusion begin, and of what advantage was it to the ancestral Monocotyledons in which it became stereotyped? That the union of seed-leaves does offer advantages to seedlings under certain conditions is clearly shown by the existence of a number of Dicotyledonous species in which they are normally united for a great part of their length.

Comparison of the species mentioned in Table I with each other shows that they have another character in common besides the possession of a cotyledonary tube. With one exception their hypocotyl is always much reduced in length, and is commonly thickened. As a rule the first internodes of the plumular axis are likewise more or less completely suppressed. Rhizophora is said to have an elongated hypocotyl, but the conditions under which it grows in tropical swamps are unique, and we cannot be surprised by exceptional adaptations to them.

The great majority of the species mentioned are tuberous : the others (Podophyllum, Serratula, Polygonum, Rheum) form 
an upright much shortened subterranean axis in which the first internodes of the stem, as well as the hypocotyl, are suppressed. The species of Anemone and Oxalis with united cotyledons are distinguished from their neighbours within those genera by their tuberous habit.

M. Sterckx remarks that among the Ranunculaceae the species with concrescent cotyledons have short subterranean hypocotyls which are generally tuberous $(38, \mathrm{pp} .80,8 \mathrm{I})$. The explanation he gives is that the united petioles of the cotyledons carry their blades upwards, and thus replace the elongated aërial hypocotyls of allied species. Lord Avebury gives a similar reason for the correlation of a tuberous hypocotyl with concrescent cotyledons among the Umbelliferae (Lubbock, 30 , II, pp. 23, 24). Darwin speaking of several pseudo-monocotyledons, together with some other species in which both cotyledons are very much reduced in size or even absent altogether, says : ' From the several cases now given, which refer to widely different plants, we may infer that there is some close connexion between the reduced size of one or both cotyledons and the formation by the enlargement of the hypocotyl or of the radicle of a so-called bulb.' He attributes this to correlation of growth: the expenditure of material in the formation of a bulb or tuber is balanced by the economy effected in the reduction of cotyledonary tissue (10, p. 97).

The pseudo-monocotyledons of Table II are in fact also characterized by the early formation of tubers, or at least by the development of a much shortened squat axis.

The formation of underground root-stocks, of tubers, corms, and bulbs, is characteristic of the plants called 'geophilous' by Professor Areschoug (3). The general definition of the term which he gives on page I is very wide: 'We include under that head such plants as form the buds by which they reproduce the shoot underground: those plants in fact which develop their aërial organs more or less completely beneath the surface of the soil.' Defined in this way the term would include all biennials and herbaceous perennials of the temperate and arctic zones, for the aërial shoots of all such plants dis- 


\section{founded on the Structure of their Seedlings. 79}

appear during the winter, and are replaced in the following spring by the development of buds formed underground.

Geophilous characters are shown most clearly by plants which put forth aërial shoots during a short annual season only. Such are the two classes of plants termed 'alpines' and 'bulbs' by gardeners. The underground organs of such plants attain to some size, not unfrequently exceeding that of the aërial shoot. They are native to situations which have a short annual period in which the conditions are favourable to vegetation, and a longer dead season. The short hot summer of the arctic regions and of alpine summits, which does not begin until the snow melts, and is followed by a long frost-bound winter; the summer in the interior of South Africa, ushered in by rains, and followed by a season of dry cold; the damp warm spring of the Mediterranean region succeeded by a hot dry summer; these are examples of climatic conditions favourable to highly specialized geophytes, and within such regions the habit was no doubt developed.

In order to use the short season of vegetation to the best advantage the geophilous plant or geophyte must be furnished with a store of nourishment, and this is placed at some distance below the surface of the soil for protection against the cold or heat of the dead season. A plant so provided can throw up leaves and flowers at a few days' notice from the bud attached to its swollen axis or tuberous root.

The leaves when once above the ground make the most of their short life. They restock the underground organs with food for the following season, and they support the flowers, and later the maturing fruit, until the seed is ripe. When this occurs before the advent of the cold or drought withers the aërial shoots, the cycle of development is complete, but in such localities it must often happen that an early frost or a dry season kills all the seed formed by a plant before it is ripe.

The fact that all the species mentioned in Table I, with the exception of Rhizophora, are highly specialized geophytes suggests very strongly that union of the cotyledons is an 
adaptation to this habit. When we consider the conditions under which a typical geophyte lives, it is very clear that its seedlings must be even more perfectly adapted to the environment than the mature plant in order to have a chance of surviving.

The seed formed at the end of the growing period is commonly capable of resisting a considerable degree of cold or drought in the long dead season. When the genial weather returns and it germinates, the seed is confronted with a difficult problem. During the short period of vegetation the growth of the seedling must proceed in such a way that the structure completed by the end of the season is capable of living through the severe weather which follows.

Accordingly we find that the seedling begins at once to form its underground organs. Not unfrequently the whole structure remains underground during the first season of growth (Megarrhiza Californica, Darwin, 10, p. 82; Arum maculatum, Rimbach, 33). More commonly the cotyledons only appear above ground in the first season (Eranthis hiemalis, Fritillaria imperialis), or the cotyledons may remain underground in the seed and the first leaf break through the soil (Anemone nemorosa, Irmisch, 23, p. 17 , Figs. 26-28; Eucomis nana, Jacq.). In other species both cotyledons and foliage leaves come up above ground in the first season and act as assimilating organs (Delphinium nudicaule, Iris sp.).

In all these cases, however, the production of assimilating surfaces seems to be an object of secondary importance to the seedling of a geophilous plant in its first season. The formation of adequate subterranean organs at a safe distance below the surface of the soil is the condition on which the life of such a seedling ultimately depends, and its powers are devoted in the first place to this task.

Concrescent cotyledons seem to be an adaptation for producing effective assimilating surfaces with the least possible expenditure of material (Lubbock, Sterckx, 1. c.). The production of a single cotyledon, whether by the more complete fusion of two or in any other way, is also an economy as 


\section{founded on the Structure of their Seedlings. 8I}

compared with the formation of two cotyledons (Darwin, 1.c.). It is true that in time the extra assimilating surfaces will more than repay the cost of their production, but time may fail the geophyte which dares not risk being caught by the bad weather unprepared.

These considerations have led me to look upon the Monocotyledon as an organism adapted primarily to a geophilous habit. The single cotyledon has been shown to be connected with this way of life in some Dicotyledons, and many of the features which distinguish Monocotyledons from Dicotyledons may be explained as having been formed under the conditions I have just described. Since I have adopted this view as a working hypothesis, the purpose of many details in the structure of Monocotyledons which had puzzled me before has become comprehensible.

\section{Distribution of the Bundles in the Stem.}

An erect subterranean axis with much shortened internodes and crowded with the sheathing bases of leaves must inevitably receive a number of traces from each leaf, and these traces-entering the axis in segments of its circumference corresponding to the breadth of the leaf-basewould naturally arrange themselves in more or less complete concentric circles. Mr. Henslow has well described the process by which this might occur $(15$, p. 5I2), but his suggestions are much more applicable to a short vertical subterranean axis such as that found in the four-year-old seedling of Podophyllum (Holm, 19) than to the rhizome of Nymphaea. In a squat underground root-stock secondary growth of the xylem in thickness would be useless: the bundles are essentially channels of communication between the leaves and the roots, and they are not required to support a great mechanical strain. Thus the extra-fascicular cambium would first disappear-as it has done in Podophyllum-and later the cambial zone from each bundle. The bundles of Podophyllum possess distinct fascicular cambium, but they are isolated from each other by the well-marked bundle-sheaths. 
Miss Andersson (2) and M. Quéva (33) have found a welldefined cambial zone within the bundles of some Monocotyledons, and traces of such formation in many others.

The tuber of Corydalis solida (Jost, 28) appears to retain normal secondary growth in thickness. The cambium forms a new tuber every year within the old one, adding to the wood a great mass of parenchymatous elements which become filled with reserve food-material. The anatomy of Dicotyledonous tubers has been somewhat neglected, but I believe this structure to be exceptional. The seedling anatomy of Delphinium sp. and Anemone coronaria suggests that it may be found in the mature tubers of these species also (pp. 54-56). The food supply, however, is more commonly stored in the conjunctive tissue and cortex (Eranthis, Podophyllum, Cyclamen, and the roots of Ramunculus Ficaria). The development of the cortex and conjunctive tissue inevitably isolates the bundles traversing the tuber.

\section{Early disappearance of the Primary Root.}

This character is by no means universal among Monocotyledons. In many arborescent species the primary root persists for a considerable time, becoming stout and well developed (Yucca, Palms). But the rule among bulbous and herbaceous species certainly is that the primary root disappears at the same time with the cotyledon. Bulbous plants as a rule lose their roots at the end of each growing season, and put out new ones at the beginning of the next. This habit is no doubt correlated with the direct connexion of each leaf with a particular root so characteristic of bulbous plants (cf. a quotation from Mirbel given by Mr. Henslow, 15, p. 506). The annual crop of roots is clearly bound up with the annual recurrence of a period of vegetative activity.

Eranthis agrees in this respect with Monocotyledons. The primary root is replaced in the second spring by a circle of roots developed in a girdle surrounding the tuber (Irmisch, 24, Fig. I5). 
founded on the Structure of their Seedlings. 83

Absence of a true Epidermis in the Root above the Rootsheath.

This character of the root is so far as we know universal among Monocotyledons, but not confined to them. It is found in the Nymphaeaceae among Dicotyledons. I can form no guess as to its origin.

\section{Parallel Venation of the Leaves.}

Parallel venation is general among the leaves of Monocotyledons, but by no means universal. Professor Areschoug has remarked that the linear leaves characteristic of most bulbous Monocotyledons are better adapted to push upwards through the soil than any Dicotyledonous type of leaf (3, p. 55). The bulb seems in many respects to be the most highly specialized form of geophyte: its squat axis and pointed leaves with their broad sheathing base are clearly adaptations to a geophilous life. The anatomy of the stem and the short life of the roots are characters correlated with those just mentioned.

\section{The Ternary Symmetry of the Flower.}

The three-whorled flower is very generally found among Monocotyledons, but is not universal. Many of the exceptions may be derived from it by reduction (Aroideae). No connexion between this symmetry and a geophilous habit occurs to me, except that the parts of the flower may perhaps pack easily into a bud when arranged in this way.

\section{The presence of an Endosperm in the Seed.}

This character is neither universal among Monocotyledons nor confined to them, but it is much more common in this class of plants than among Dicotyledons. I believe it to be a character common to the majority of highly specialized geophytes. This is illustrated by the fact that among the twenty-seven Dicotyledonous genera mentioned in Tables I and II, three only (Cardamine, Serratula, and Pinguicula) 
possess exalbuminous seeds. The connexion is not difficult to understand. The seed of geophilous plants must become ripe within a short period, and the embryo therefore remains small, and commonly but little differentiated, while the endosperm is packed with food-stuff.

With this is connected the slow germination of many species with concrescent cotyledons. The prolonged maturation of the embryo within the seed of Ramunculus Ficaria-a process extending over nearly two years after the seed is ripe-has been mentioned already. It is fully described by M. Sterckx (38, p. 42, Figs. I 5 I-I60). A similar maturation of the embryo takes place in the seeds of Eranthis hiemalis, Corydalis cava (Schmid, 1.c.), and of several species of Anemone after they are shed, but here the process is complete at the end of the first season and the seeds germinate in the following spring (Sterckx, 38, p. 79). M. Sterckx' observations, however, were made on plants growing in a temperate climate with a long summer. It is very probable that the seeds of these species if shed at the end of a short alpine or arctic summer might defer the maturation of their embryos to the next year, and germinate only in the second summer after dispersal. The slow germination of many Monocotyledonous seeds, particularly those belonging to bulbous species, is a fact familiar to all gardeners.

The suggestions here made as to the origin of Monocotyledons from a Dicotyledonous stock will perhaps be thought worthy of consideration by botanists. It is certain that if the theory be adopted as a working hypothesis it will suggest new lines of research, for example a more complete investigation of the embryology of Monocotyledons and the anatomical investigation of geophilous Dicotyledons. Not less important is the study of seedlings and immature plants in the field, in continuation of the work of Irmisch, Holm, and others. 


\section{founded on the Structure of their Seedlings. 85}

\section{INDEX TO SPECIES MENTIONED.}

Abronia arenaria, 77.

Abronia grandiflora, 77 .

Abronia umbellata, 77 .

Acanthophoenix crinita, 48 .

Aconitum Anthora, 73.

Agave Rovelliana, 42.

Agave spicata, 41.

Albuca Nelsoni, 9, 23.

Allium angulosum, 32.

Allium ascalonium, $3 \mathbf{I}$.

Allium Cepa, 3 I.

Allium neapolitanum, 3 I.

Allium Porrum, 3I.

Allium serufschanicum, 3 I.

Aloë Buchanii, 38 .

Alstroemeria (gar. var.), 4I.

Amomum angustifolium, 50.

Anemarrhena asphodeloides, 4, 26.

Anemone alpina, 73 .

Anemone apennina, 65,75 .

Anemone blanda, 73 .

Anemone coronaria, 56, 73 .

Anemone narcissiflora, 73 .

Anemone nemorosa, 65,80 .

Anemone rupicola, 73 .

Anthericum Liliago, 29.

Anthurium Bakerianum, 2, 40,

45.

Areca sapida, 48 .

Arisaema speciosum, 45.

Arthropodium cirrhatum, 30 .

Arum maculatum, 44, 80.

Asparagus decumbens, 37 .

Asparagus officinalis, 37 .

Asphodeline liburnica, 26.

Asphodelus albus, 27.

Asphodelus cerasifer, 27 .

Asphodelus fistulosus, 27.

Bloomeria aurea, 32.

Bongardia Rauwolfii, 73.

Bravoa geminiflora, $4 \mathbf{I}$.

Brodiaea lactea, $\mathbf{3}^{2}$.

Bulbine annua, 9, 28.
Bunium luteum, 74.

Bunium petraeum, 76 .

Canna sp., 50.

Capnorchis Cucullaria, 76 .

Cardamine (Dentaria), 73,84 .

Carum alpinum, 76.

Carum Bulbocastanum, 76 .

Chaerophyllum bulbosum, 74 .

Chamaerops Fortunei, 49.

Chamaerops humilis, 49 .

Chlorogalum pomeridianum, 29.

Cordyline australis, 34 .

Corydalis cava, 69, 76,84 .

Corydalis fabacea, 76 .

Corydalis ochroleuca, 69 .

Corydalis solida, $76, \mathbf{8 2}$.

Corydalis tuberosa, D.C., 76 .

Cotula coronopifolia, 75 .

Cyclamen persicum, 76 .

Delphinium fissum, 73.

Delphinium hybridum, 73.

Delphinium nudicaule, $54,73,80$.

Delphinium ochroleucum, 73 .

Delphinium puniceum, 73.

Delphinium Requienii, 53 .

Delphinium sp., 54 .

Dentaria, 73,83 .

Desmoncus minor, 48 .

Desmoncus sp., 48 .

Dicentra Cucullaria, 76 .

Dipcadi serotinum, I 2.

Dodecatheon Meadia, 74.

Doryanthes excelsa, $4^{2}$.

Doryanthes Palmeri, 42 .

Dracaena Draco, 36 .

Echinocystis fabacea, 74 .

Elettaria cardamomum, 50.

Eranthis hiemalis, 5, 56, 73, 80, 82,

84.

Eremurus spectabilis, 27 .

Eremurus turkestanicus, 27. 


\section{Sargant. - Theory of the Origin of Monocotyledons}

Erigenia bulbosa, Nutt., 76 . Erythronium Hartwegi, 23, 25. Eucomis nana, Jacq., I8, 8o. Euterpe edulis, 50.

Ferula foetida, 75 .

Freesia sp., 44.

Fritillaria alpina, 25.

Fritillaria imperialis, 23, 80 .

Galtonia candicans, I2.

Geonoma oxycarpa, 49 .

Hyacinthus orientalis, 20. Hyacinthus romanus, I4.

Iris Boissieri, 43 .

Iris sibirica, 43.

Iris sp., 43,80 .

Lachenalia Nelsoni, 2 I.

Leontice altaica, 73 .

Leontice Leontopetalon, 73.

Leontice vesicaria, 73 .

Lilium croceum, 25.

Lilium Henryi, 25.

Lilium sp., 25.

Megarrhiza californica, 74,80 .

Milla biflora, $3^{2}$.

Muretia tanaicensis, 74 .

Musa Livingstonia, 50.

Muscari armenaicum, I6.

Muscari atlanticum, I5.

Muscari comosum, 20.

Muscari neglectum, I8.

Nelumbium, 70.

Nigella damascena, 53 .

Ornithogalum exscapum, 2 I.

Ornithogalum sulphureum, 20.

Oxalis, 73 .

Phlomis tuberosa, 75 . Phoenix dactylifera, 49.

Pinguicula caudata, 75,83 .
Pinguicula grandiflora, $75,76,83$.

Pinguicula lusitanica, 75,83 .

Pinguicula vulgaris, $75,76,83$.

Podophyllum Emodi, 73, 77.

Podophyllum peltatum, $73,77,81$.

Polygonum bistorta, 74, 77 .

Polygonum sphaerostachyum, 74, 77.

Prangos ferulacea, 74.

Ranunculus Chius, 65 .

Ranunculus Ficaria, 63,75 .

Ranunculus millefoliatus, 64,75 .

Ranunculus parnassifolius, 64,73 .

Ranunculus repens, 65 .

Renealmia racemosa, $5 \circ$.

Rheum Moorcroftianum, 74, 77.

Rheum officinale, 75,77 .

Rhizophora conjugata, 74, 77 .

Rhizophora Mangle, 74, 77.

Scilla festalis, 20.

Scilla peruviana, 2 I .

Scilla sibirica, 20.

Serratula radiata, $74,77,83$.

Serratula tinctoria, $75,77,83$.

Smyrnium Olusatrum, 74 .

Smyrnium perfoliatum, 74 .

Smyrnium rotundifolium, 74 .

Tamus communis, 9,70 .

Thrinax excelsa, 48 .

Tricyrtis hirta, 33 .

Trillium grandiflorum, 34 .

Trollius Ledebouri, 73.

Tulipa praecox, 25 .

Tulipa sp., 25.

Urtica dioica, 75 .

Veratrum nigrum, 33.

Yucca aloifolia, 35, 39.

Yucca arborescens, 35 .

Yucca gloriosa, 36, 39 .

Zygadenus elegans, $3^{2}$. 


\section{founded on the Structure of their Seedlings. 87}

\section{REFERENCES TO LITERATURE.}

1. Agardh, C. A. : Lärobok i Botanik. Part I. Malmö, I829-32.

2. ANDERSSON, S.: Ueber die Entwickelung der primären Gefässbündelstränge der Monokotylen. Bihang till K. Sv. Vet. Akad. Handl., Bd. xiii, $\mathbf{1} 888$. (Full abstract in Bot. Centralblatt, vol. xxxviii, I889, pp. 586 and 618.)

3. Areschoug, F. W.C.: Beiträge zur Biologie der geophilen Pflanzen. Lund, 1896.

4. BERnHARDI : Ueber die merkwürdigsten Verschiedenheiten des entwickelten Pflanzenembryos und ihren Werth für Systematik. Linnaea, vol. vii, 1832 .

5. Bischoff, G. W. : Beobachtungen über den Gang des Keimens ... bei Corydalis-Arten. Tiedemann's Zeitschr. f. Physiologie, Bd. iv, I83 r, p. I46.

6. Buchenau, Fr. : Morphologische Studien an deutschen Lentibularieen. Bot. Zeit., 1865 , p. 64 .

7. CAMpbell, D. H.: On the Affinities of certain anomalous Dicotyledons. American Naturalist, vol. xxxvi, 1902, p. 7 .

8. Chaveaud, G. : Passage de la position alterne à la position superposée de l'appareil conducteur... dans le cotylédon de l'oignon (Allium cepa). Bull. Mus. Hist. Nat. Paris, 1902, p. $5^{2}$.

9. Dangeard, P.: Recherches sur le mode d'union de la tige et de la racine. Le Botaniste, I, I889.

10. Darwin, Ch.: The Power of Movement in Plants. London, I880.

11. Dickson, A.: On the Development of the Flower of Pinguicula vulgaris, L., with remarks on the embryos of P. vulgaris, P. Grandiflora, P. lusitanica, P. caudata and Utricularia minor. Trans. Roy. Soc. Edin., vol. xxv, I869, p. 639. (Abstract in Bot. Zeit., I870, p. 220.)

12. - On the Germination of Podophyllum Emodi. Trans. Bot. Soc. Edinburgh, vol. xvi, $\mathbf{1} 882$.

13. Gérard, R.: Recherches sur le passage de la racine à la tige. Ann. d. Sci. Nat., sér. vi, Botanique, I88I, p. 279.

14. Hegelmaier, F. : Vergleichende Untersuchungen über Entwickelung dikotyledoner Keime. Stuttgart, 1878 .

15. Henslow, G. : A Theoretical Origin of Endogens from Exogens by SelfAdaptation to an Aquatic Habit. Linn. Soc. Journ., xxix, I892, p. 485 .

16. Hildebrandt, F.: Die Lebensverhältnisse der Oxalis-Arten. Jena, i 884.

17. - Einige Beobachtungen an Keimlingen und Stecklingen. Bot. Zeit., 1892.

18. Holm, Theod. : Contributions to the Knowledge of the Germination of some North American Plants. Mem. of the Torrey Bot. Club, vol. ii, I 89I.

19. Podophyllum peltatum : a morphological study. Bot. Gazette, vol. xxvii, I 899 , p. 4 I9.

20. Erigenia bulbosa, Nutt. A morphological and anatomical study. Amer. Journ. of Science, Jan. I90I.

21. IRmisch, Thilo: Beiträge zur vergleichenden Morphologie der Pflanzen. Abth. I. Halle, I854. 


\section{Sargant.-Theory of the Origin of Monocotyledons.}

22. Irmisch, Thilo: Beiträge zur vergleichenden Morphologie der Pflanzen. Abth. 2. Halle, I 856 .

23. - Ueber einige Ranunculaceae. Bot. Zeit., I856.

24. - Ueber einige Ranunculaceae. Bot. Zeit., I860.

25. Ueber einige Fumariaceae. Abhandl. d. Naturf. Gesell. Halle, Bd. vi, I862.

26. - Ueber einige Ranunculaceae. Bot. Zeit., I865.

27. Einige Bemerkungen über Aconitum Anthora. Abhandl. v. naturwiss. Vereine zu Bremen, Bd. iii, 1873 , p. $3^{6} 5$.

28. Jost, L. : Die Erneuerungsweise von Corydalis solida, Sn. Bot. Zeit., I89o, p. 257 .

29. KlebS, G.: Beiträge zur Morphologie und Biologie der Keimung. Unters. a. d. Bot. Inst. zu Tübingen, Bd. i, Leipzig, I88I-5, p. 536 .

30. Lubbock, Sir J.: A Contribution to our Knowledge of Seedlings. London, 1892 , vols. $i$ and ii.

31. Lyon, H. L.: Embryogeny of Nelumbo. Minnesota Bot. Studies, ii, p. 643, Igor.

32. Qứva, C.: Contributions à l'anatomie des Monocotylédonées. Trav. et Mém. de l'Université de Lille, 1900.

33. Rimbach, A.: Ueber die Lebensweise des Arum maculatum. Ber.d. deutsch. bot. Gesell., I 897 .

34. Sargant, E. : A new Type of Transition from Stem to Root in the Vascular System of Seedlings. Ann. of Bot., vol. xiv, I900, p. 633 .

35. The Origin of the Seed-Leaf in Monocotyledons. New Phytologist, vol. i, 1902, p. I07.

36. Scott, R., ANd Sargant, E.: On the Development of Arum maculatum from the Seed. Ann. of Bot., vol. xii, I898, p. 399.

37. Solms-Laubach, Graf zU: Ueber monocotyle Embryonen mit scheitelbürtigem Vegetationspunkt. Bot. Zeit., I878, p. 65 .

38. Sterckx, R. : Recherches anatomiques sur l'embryon et les plantules dans la famille des Rénonculacées. Mém. de la Soc. roy. d. Sci. de Liège, sér. iii, tom. ii, 1899 .

39. Strasburger, E.: Ein Beitrag zur Kenntniss von Ceratophyllum submersum und phylogenetische Erörterungen. Prings. Jahrb., vol. xxxvii, I902, p. 477 .

40. Tansley, A. G.: 'Reduction' in Descent. New Phytologist, vol. i, I902, p. I3I.

41. Van Tieghem, Ph. : Morphologie de l'embryon et de la plantule chez les Graminées et les Cyperacées. Ann. d. Sci. Nat., sér. viii, tom. iii, 1897, p. 259.

42. Winkler, A. : Ueber die Keimblätter der deutschen Dicotylen. Verhandl. d. bot. Vereins d. Provinz Brandenburg, Bd. xvi, I874.

43. - Ueber einige Pflanzen der deutschen Flora deren Keimblattstiele scheidig verwachsen sind. Ibid., Bd. xxvii, $\mathbf{1} 885$.

44. - Die Keimpflanze des Ranunculus parnassifolius. Ibid., xxxv, I893, p. 160.

45. - Anomale Keimungen. Ibid., xxxvi, I894, p. I27. 


\section{founded on the Structure of their Seedlings.}

\section{EXPLANATION OF FIGURES IN PLATES I-VII.}

Illustrating Miss Sargant's paper on the Origin of Monocotyledons.

The figures on Plates I and II are drawn by Miss E. Sargant, with the exception of Fig. 5 on Plate I (Miss E. N. Thomas).

The figures on Plates III-VII are drawn by Miss Agnes Robertson, with the exception of those marked (E. S.) or (E. N. T.).

\section{PLATE I.}

\section{Albuca Nelsoni.}

Fig. I. Outline of whole seedling $A_{5}$, drawn from life. $\times 1 / 1$. Outline of young bulb and adjacent parts from seedling $B_{1}$, preserved in spirit. $\times 1 / 1$.

Fig. 2. From microtome series through seedling $A_{3}$. Transverse section of embryonic stem-bud enclosed in expanded base of cotyledon. $\times 75$.

Fig. 3. From same series, $\cdot 16 \mathrm{~mm}$. below Fig. 2. Transverse section through transitional region. Each main cotyledonary trace has formed three protoxylem groups: $p x_{1}, p x_{2}, p x_{3}$, and $p x_{4}, p x_{2}{ }^{\prime}, p x_{3}{ }^{\prime} . \quad \times 2$ IO.

Fig. 4. From same series, $\cdot I_{2} \mathrm{~mm}$. below Fig. 3. Triarch root forming, but original tetrarch structure indicated by presence of protoxylem group $p x_{3}+p x_{3}^{\prime}$. $\times 2$ I0.

\section{Hyacinthus romanus.}

Fig. 5. Outline of seedling $A_{5}$, from life. $\times 1 / 1$. (E. N. T.)

Fig. 6. From microtome series through seedling $A_{5}$. Transverse section through embryonic stem-bud enclosed in expanded base of cotyledon. Two main bundles, $M_{1}, M_{2}$, and four lateral strands in cotyledon. $\times 75$.

Fig. 7. From same series, $\cdot 27 \mathrm{~mm}$. below Fig. 6. Formation of phloëm girdle indicated. Two lateral bundles, $l_{1}, l_{2}$, unite with main bundles, $M_{1}, M_{2}$, to form stele. $\times 225$.

Fig. 8. From same series, $\cdot 04 \mathrm{~mm}$. below Fig. 7. The whole xylem of bundles $l_{1}, l_{2}$, has joined the lowest group derived from the main bundles, $p x_{3}+p x_{3}{ }^{\prime}$. $\times 225$.

Fig. 9. From same series, $.13 \mathrm{~mm}$. below Fig. 8 . Tetrarch root-stele. The last-formed group of protoxylem, $p x_{1}$, is smaller than the others. $\times 225$.

\section{PLATE II.}

\section{Muscari atlanticum.}

Fig. I. Outline of seedling $A_{4}$, preserved in spirit. $\times 1 / 1$.

Fig. 2. From microtome series through seedling $A_{4}$, just below first node. Two main cotyledonary traces, $M_{1}, M_{2}$, and two lateral ones, $l_{1}, l_{2}$, in stele. $\times 200$.

Fig. 3. From same series, $.03 \mathrm{~mm}$. below Fig. 2. Pentarch root-stele indicated. The two lateral traces $\left(l_{1}, l_{2}\right.$ in Fig. 2$)$ have supplied the lowest phloëm group. $\times 300$. 


\section{Sargant.-Theory of the Origin of Monocotyledons}

\section{Muscari armenaicum.}

Fig. 4. Outline of seedling $A_{3}$, drawn from life. $\times 1 / 1$.

Fig. 5. From microtome series through seedling $A_{3}$, at base of first node. The lateral trace $l_{3}$ is inserting itself on $l_{1}$. The two main traces, $M_{1}, M_{2}$, are united by the common protoxylem group, $p x_{2}+p x_{2}^{\prime} . \quad \times 200$.

Fig. 6. From same series, $.07 \mathrm{~mm}$. below Fig. 5. Pentarch root-stele indicated. The lateral traces supply the two lower phloëm groups and the protoxylem group between them, $p x_{5}$, with part of two others. $\times 300$.

Fig. 7. Outline of seedling $A_{5}$, drawn from life. $\times 1 / 1$.

Fig. 8. From microtome series through seedling $A_{5}$, just below first node. Two main cotyledonary traces, $M_{1}$ and $M_{2}$, and two lateral ones, $l_{1}, l_{2}$. $\times 200$.

Fig. 9. From same series, $.07 \mathrm{~mm}$. below Fig. 8. Tetrarch root-stele indicated. The lateral traces $\left(l_{1}, l_{2}\right.$, in Fig. 8) form half the stele, supplying the two lower phloëm groups-which are sensibly smaller than the upper ones-the whole of the protoxylem group $p x_{5}$, and part of groups $p x_{3}$ and $p x_{3}{ }^{\prime} . \quad \times 300$.

\section{PLATE III.}

\section{Fritillaria imperialis.}

Fig. I. Outline of seedling $A_{1}$, drawn from life. $\times 1 / 1$.

Fig. 2. From microtome series through seedling $A_{1}$. Transverse section through enlarged base of cotyledon, enclosing young stem-bud. Two massive bundles, $M_{1}, M_{2}$, in cotyledon: three strands in first leaf. $\times 66$.

Fig. 3. From same series, $\cdot 32 \mathrm{~mm}$. below Fig. 2. First node. Two plumular traces are inserted on $M_{1}, M_{2}$. One branch from the protoxylem of $M_{1}$ goes to meet the nearest plumular trace ; the other forms part of the group $p x_{2}$ at the top of the section. The protoxylem of $M_{2}$ divides in the same way. $\times 200$.

Fig. 4. From same series, $.18 \mathrm{~mm}$. below Fig. 3. Insertion of plumular traces is completed. The xylem group of $M_{1}$ and $M_{2}$ are each crescent-shaped. The protoxylem of each crescent covers its convex outline: the concavity is occupied by a compact phloëm group. $\times$ I 33 .

Fig. 5. From same series, $.03 \mathrm{~mm}$. below Fig. 4. Protoxylem crescents broken into two groups, $p x_{2}, p x_{3}$. The structure is that of a diarch root with two thin plates of protoxylem extended tangentially. $\times 133$.

Fig. 6. From same series, ${ }^{2} 5 \mathrm{~mm}$. below Fig. 5. Phloëm in four groups : protoxylem breaking up into four too. Tetrarch root-stele indicated. $\times$ I 33 .

\section{PLATE IV.}

\section{Chlorogalum pomeridianum.}

Fig. I. Outline of seedling $A_{3}{ }^{\prime}$, preserved in spirit. $\times 1 / 1$. (E. N. T.)

Fig. 2. From microtome series through seedling $A_{3}{ }^{\prime}$, just above first node. Double cotyledonary trace $M_{1}+M_{2}$ with three protoxylem groups, $p x_{1}, p x_{2}, p x_{3}$. Single plumular trace, which divides as it approaches cotyledonary trace into two branches, $\mathrm{Pl}_{1}, \mathrm{Pl}_{2}$. $\times 2{ }^{5}$. (E. S.)

Fig. 3. From same series, $.02 \mathrm{~mm}$. below Fig. 2. Phloëm masses above and below xylem. Four protoxylem groups, of which $p x_{1}^{\prime}$ is plumular. Diarch rootstele is suggested. $\times 25^{\circ}$.

Fig. 4. From same series, $.10 \mathrm{~mm}$. below Fig. 3. Tetrarch root-stele. $\times 25^{0}$. 


\title{
founded on the Structure of their Seedlings. 9 I
}

\author{
Anthericum Liliago.
}

Fig. 5. Outline of seedling $B_{1}$, preserved in spirit. $\times 1 / 1$. (E. S.)

Fig. 6. From microtome series through seedling $B_{1}$, just above first node. The section cuts each plumular trace twice : in situ within the first leaf $(A, B, C)$, and also as they approach the double trace of the cotyledon in two groups $\left(P l_{1}, P l_{2}\right)$. $\times 190$.

Fig. 7. From same series, I $4 \mathrm{~mm}$. below Fig. 6. The phloëm is in two masses, but there are four distinct groups of protoxylem, $p x_{1}, p x_{z}, p x_{3}, p x_{1}{ }^{\prime}$. $\times 190$.

\section{Arthropodium cirrhatum.}

Fig. 8. Outline of seedling $B_{1}$, preserved in spirit. $\times 1 / 1$. (E. S.)

Fig. 9. From microtome series through seedling $B_{1}$, above first node. The double trace from the cotyledon is moving towards the plumular traces $\mathrm{Pl}$. $\times 250$.

Fig. I0. From same series, $.18 \mathrm{~mm}$. below Fig. 9. The whole stele has been somewhat twisted in its descent. But it is clear from intermediate sections that $p x_{1}$ represents the cotyledonary and $p x_{1}{ }^{\prime}$ the plumular protoxylem. The stele is root-like and diarch, but at,++ , are two small protoxylem groups in course of extinction. $\times 250$.

\section{PLATE V.}

\section{Allium neapolitanum.}

Fig. I. From microtome series through seedling $A_{4}$. Transverse section of embryonic stem-bud enclosed within enlarged base of cotyledon. Double bundle in cotyledon: three strands in first leaf. $\times 75$.

Fig. 2. From same section as Fig. I. Double bundle of cotyledon enlarged. $\times 200$.

Fig. 3. From same series, $.27 \mathrm{~mm}$. below Fig. I, through first node. The phloëm of the slender plumular trace has divided, and one branch fuses with each of the two cotyledonary phloëm groups. $\times 200$.

Fig. 4. From same series, $.04 \mathrm{~mm}$. below Fig. 3. Diarch root-stele. $\quad \times 75$.

Fig. 5. From same section as Fig. 4. Stele enlarged. $\times 200$.

\section{Zygadenus elegans.}

Fig. 6. Outline of seedling $A_{3}$, drawn from life. $\times 1 / 1$. (E. S.)

Fig. 7. Transverse hand-section through petiole of cotyledon, showing single bundle. $\times 75$.

Fig. 8. From same section as Fig. 7. Bundle enlarged. $\times 200$.

Fig. 9. From microtome series through seedling $A_{3}$. Transverse section of young stem-bud enclosed within enlarged base of cotyledon. Single bundle in cotyledon: three strands in first leaf. $\times 75$.

Fig. 10. From same section as Fig. 9. Bundle enlarged.

Fig. II. From same series, $.18 \mathrm{~mm}$. below Fig. 9, through first node. A single plumular trace meets that from the cotyledon: both open out as they approach each other, and the phloëm groups unite in pairs. $\times 200$.

Fig. 12. From same series, $.07 \mathrm{~mm}$. below Fig. 11 . Diarch root-stele indicated, but not yet formed. The upper protoxylem group is derived from the cotyledon; the lower from the plumular trace. $\times 200$. 


\title{
92 Sargant.-Theory of the Origin of Monocoty'edons.
}

\author{
PLATE VI.
}

\section{Eranthis hiemalis.}

Fig. I. Outline of seedling $A_{6}$, drawn from life. $\times 1 / 1$. (E. S.)

Fig. 2. From microtorne series through seedling $A_{2}$. Trausverse section of embryonic stem-bud enclosed within base of cotyledonary tube. $\times$ II 3 .

Fig. 3. From same series, $.09 \mathrm{~mm}$. below Fig. 2, passing through top of tuber. Each trace from the cotyledon, $C_{1}, C_{2}$, shows double structure. $\times$ II 3 .

Fig. 4. From same series, . $10 \mathrm{~mm}$. below Fig. 3. The two pairs of bundles are drawn side by side; the xylem of each is in three groups. $\times$ II 3.

Fig. 5. From same series, $.07 \mathrm{~mm}$. below Fig. 4. Four phloëm and eight xylem groups. $\times$ II 3.

Fig. 6 . From same series, $\cdot 73 \mathrm{~mm}$. below Fig. 5 , approaching the base of the tuber. The scattered traces have gathered together, and now form two phloëm and four xylem groups. Three of the latter are complete: the fourth is forming to the SW. of the section. $x$ I I 3 .

\section{PLATE VII.}

\section{Eranthis hiemalis.}

Fig. I. From same series as Fig. 6 on Plate VI, and $.27 \mathrm{~mm}$. below it. Between each of the two phloëm groups and the xylem internal to it, there are a few unlignified secondary elements in a radial row. $p x^{\prime}, p x^{\prime}$, are the two groups of protoxylem within the phloëm groups, which will disappear lower down. $\times 200$.

Fig. 2. From same series, ${ }^{\prime} 5 \mathrm{~mm}$. below Fig. I, through top of primary root. Diarch root-stele; the groups $p x^{\prime}, p x^{\prime}$, have disappeared. $\times 200$.

Fig. 3. From microtome series through older seedling $A_{5}$. The section passes through the base of the tuber. Tetrarch xylem-plate. The elements $p x^{\prime}, p x^{\prime}$ are primary. $\times 200$.

\section{Ramunculus Ficaria.}

Fig. 4. Outline of seedling $A_{3}$, drawn from life. $\times 1 / 1$. (E. S.)

Fig. 5. Outlines of the cotyledons from three seedlings, $A_{3}, A_{4}, B_{1}$, showing the venation of the blade. $\times 2$. (E. S.)

Fig. 6. From microtome series through seedling $A_{3}$, cutting axis near insertion of first cauline root. The slender plumular trace in the upper part of the section is approaching the larger trace from the cotyledon in the lower part. $\times$ roo.

Fig. 7. From same series, $.09 \mathrm{~mm}$. below Fig. 6, cutting axis at first node. The trace from the cotyledon is cut longitudinally as it approaches the plumular trace. Its double structure is clear, and the plumular trace is branching in two directions to meet it. $\times 25^{\circ}$.

Fig. 8. From same series, only $.03 \mathrm{~mm}$. below Fig. 7. The diarch root-stele is almost complete. The lower protoxylem group is from the cotyledon; the upper one from the plumule. $\times 25^{\circ}$. 

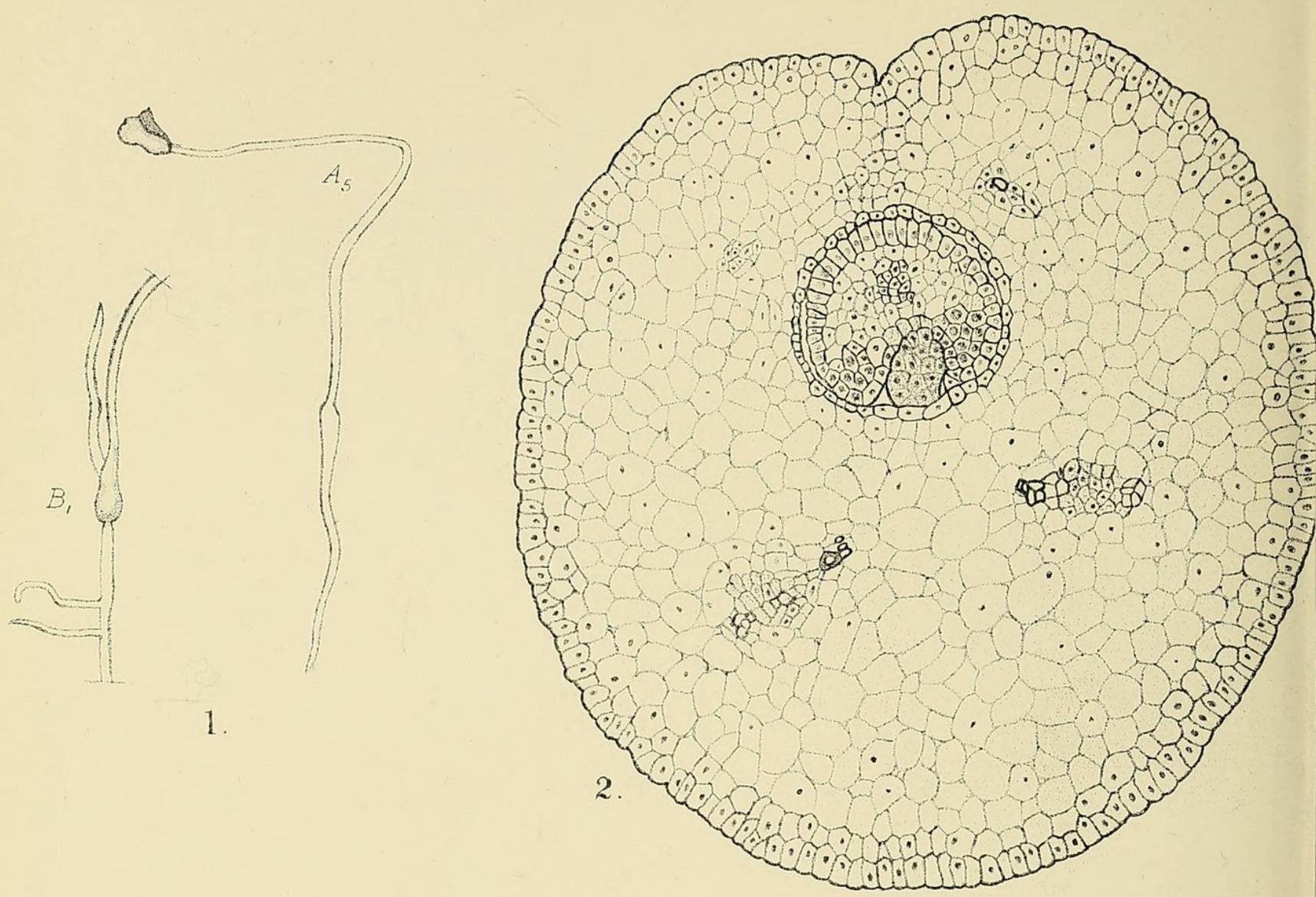

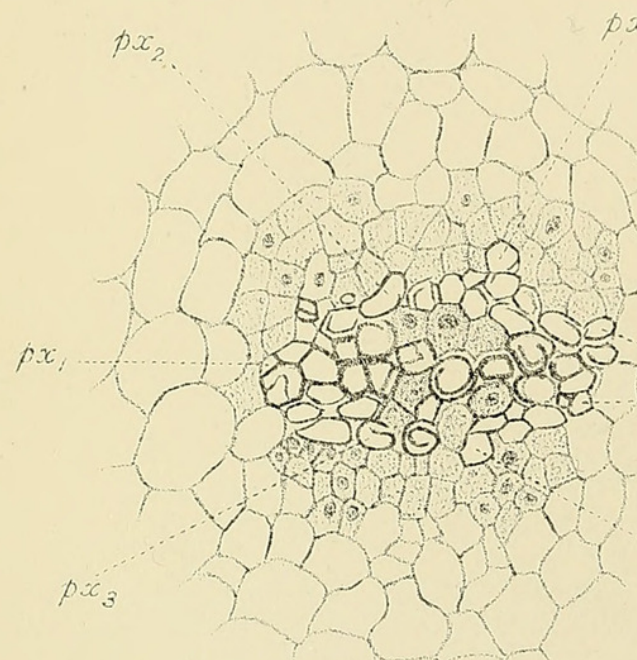

3

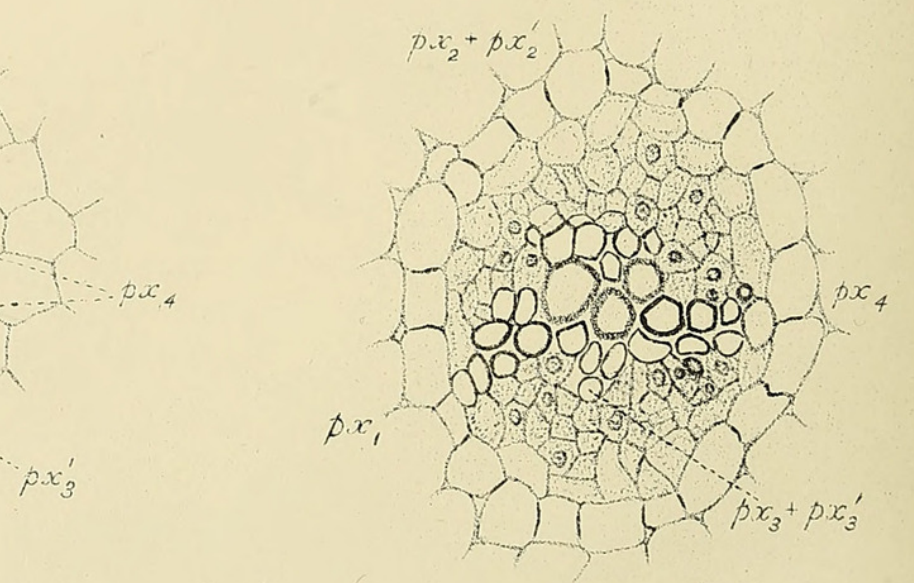

4.

Albuca Nelsoni, Figs. 1-4. 

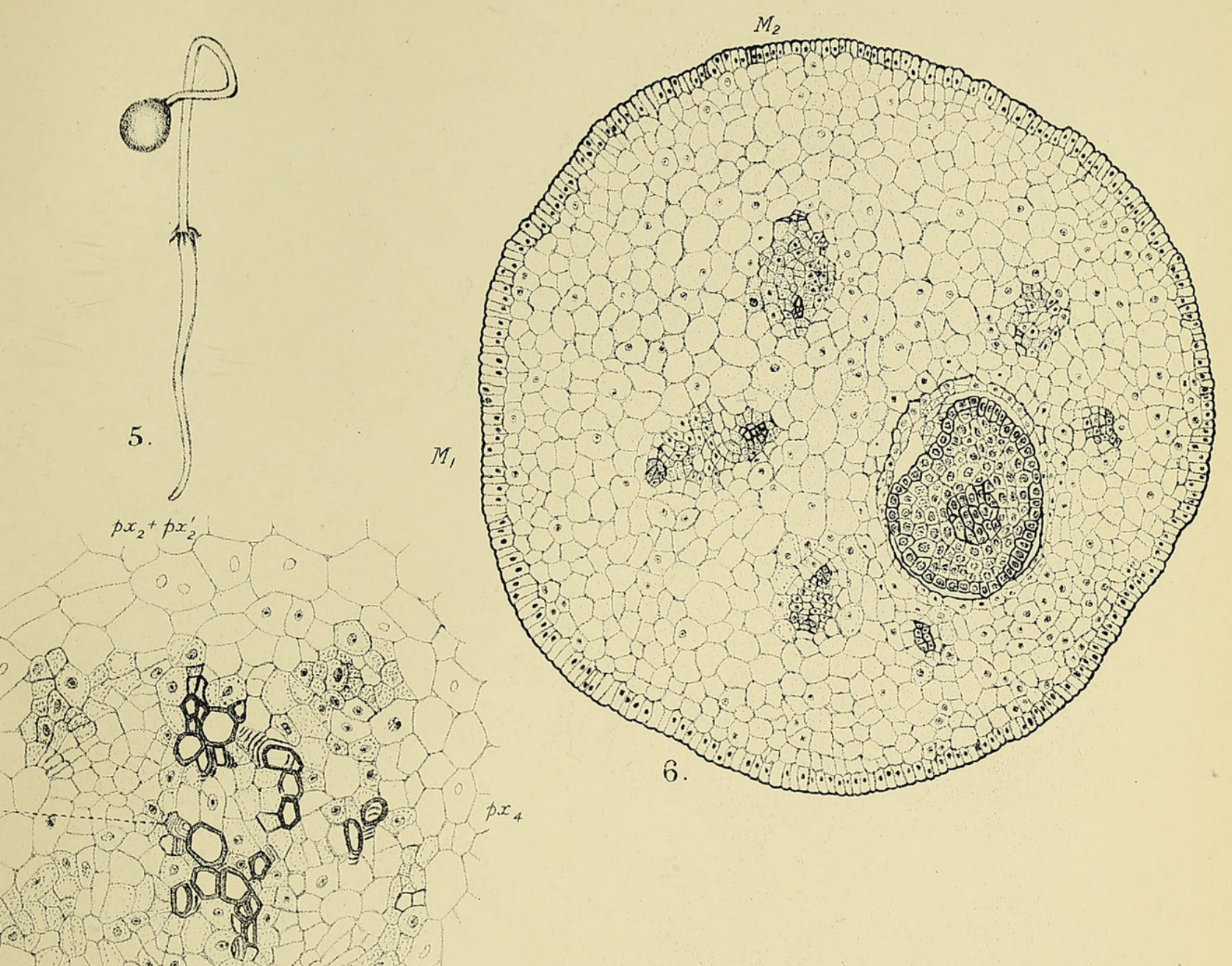

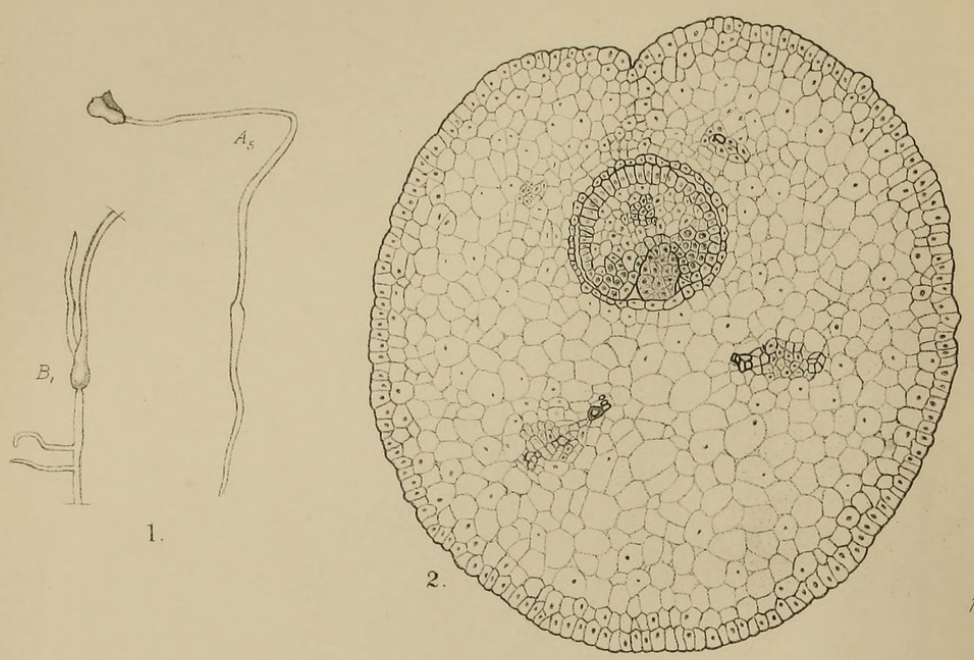

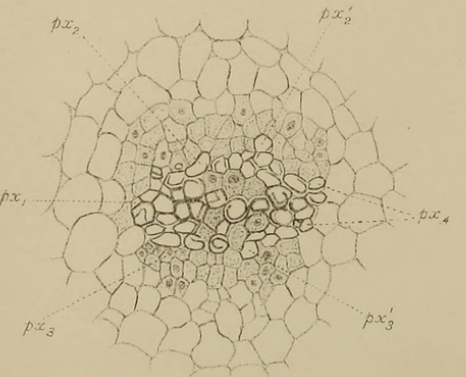

3.

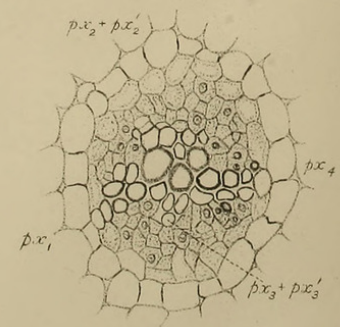

4.

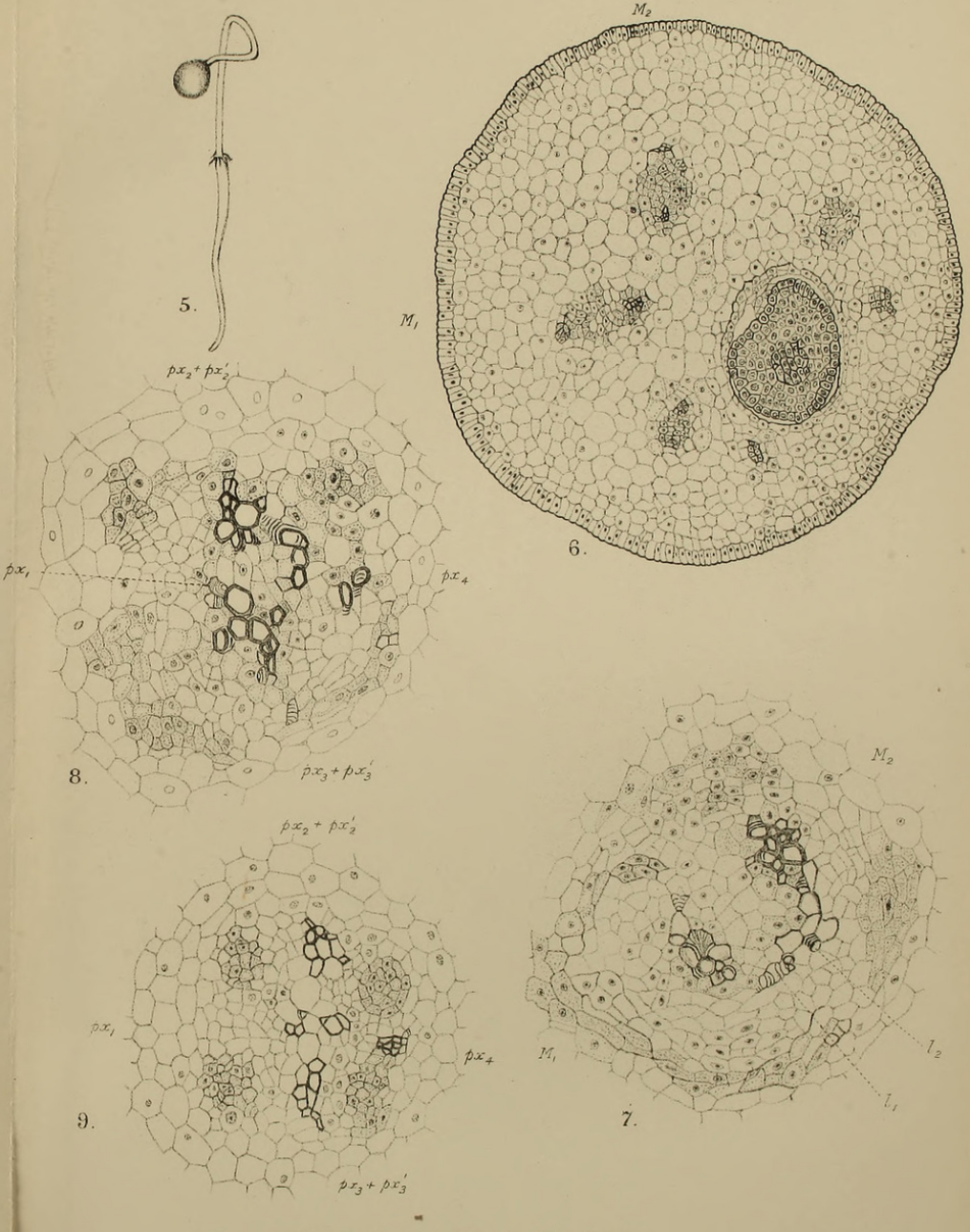

Hyacinthus romanus, Fiǵs. 5-9. 

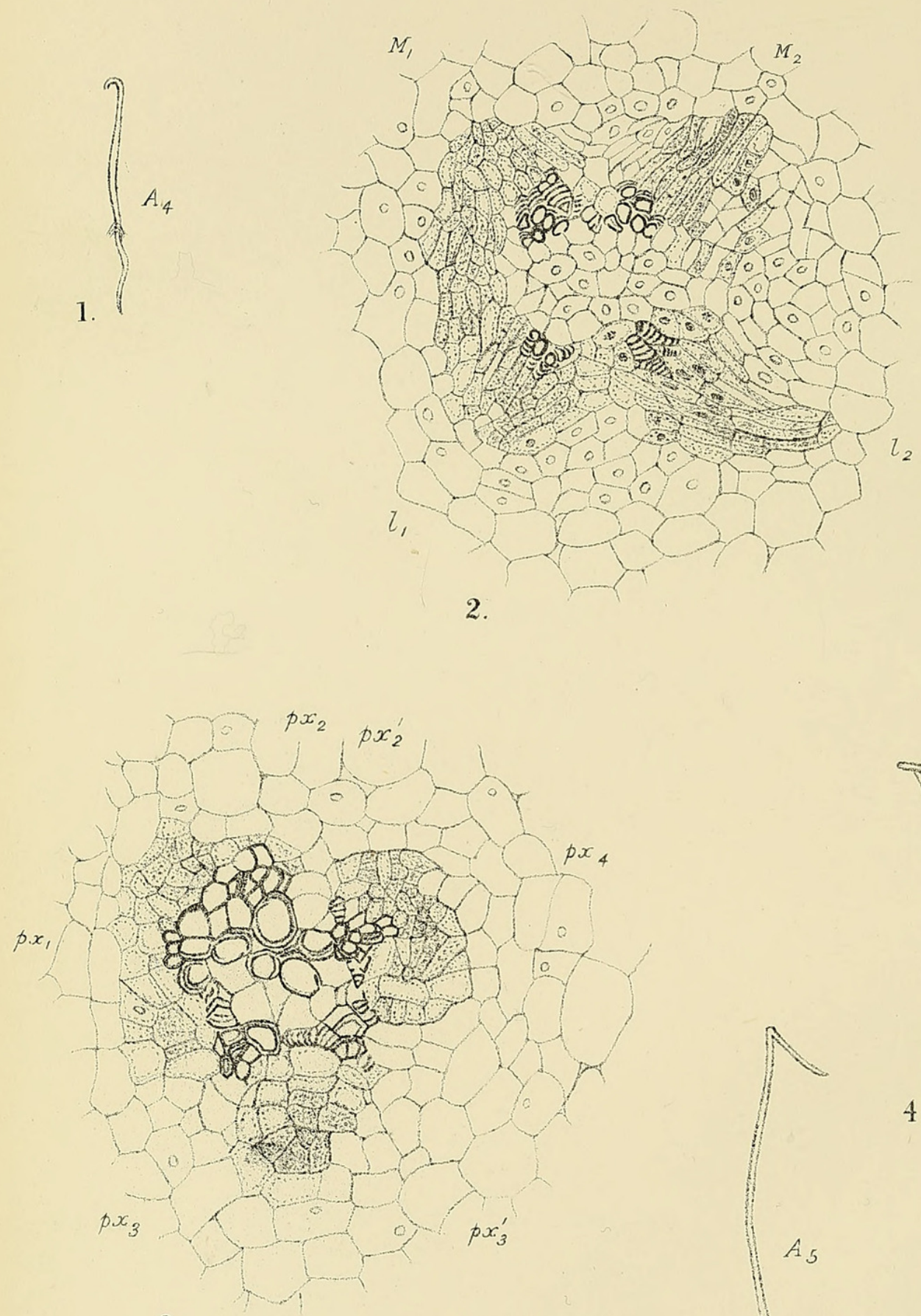

3.

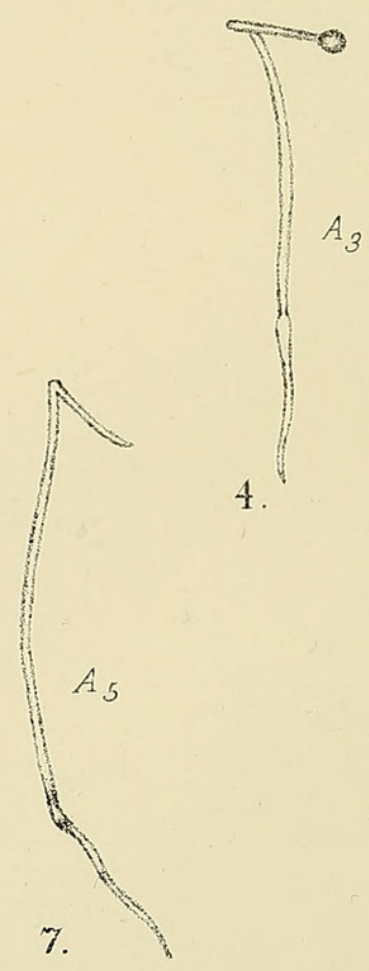

Muscari atlanticum, Figs.1-3.

6.

Muscari armenaicum, Figss. 4-9. 

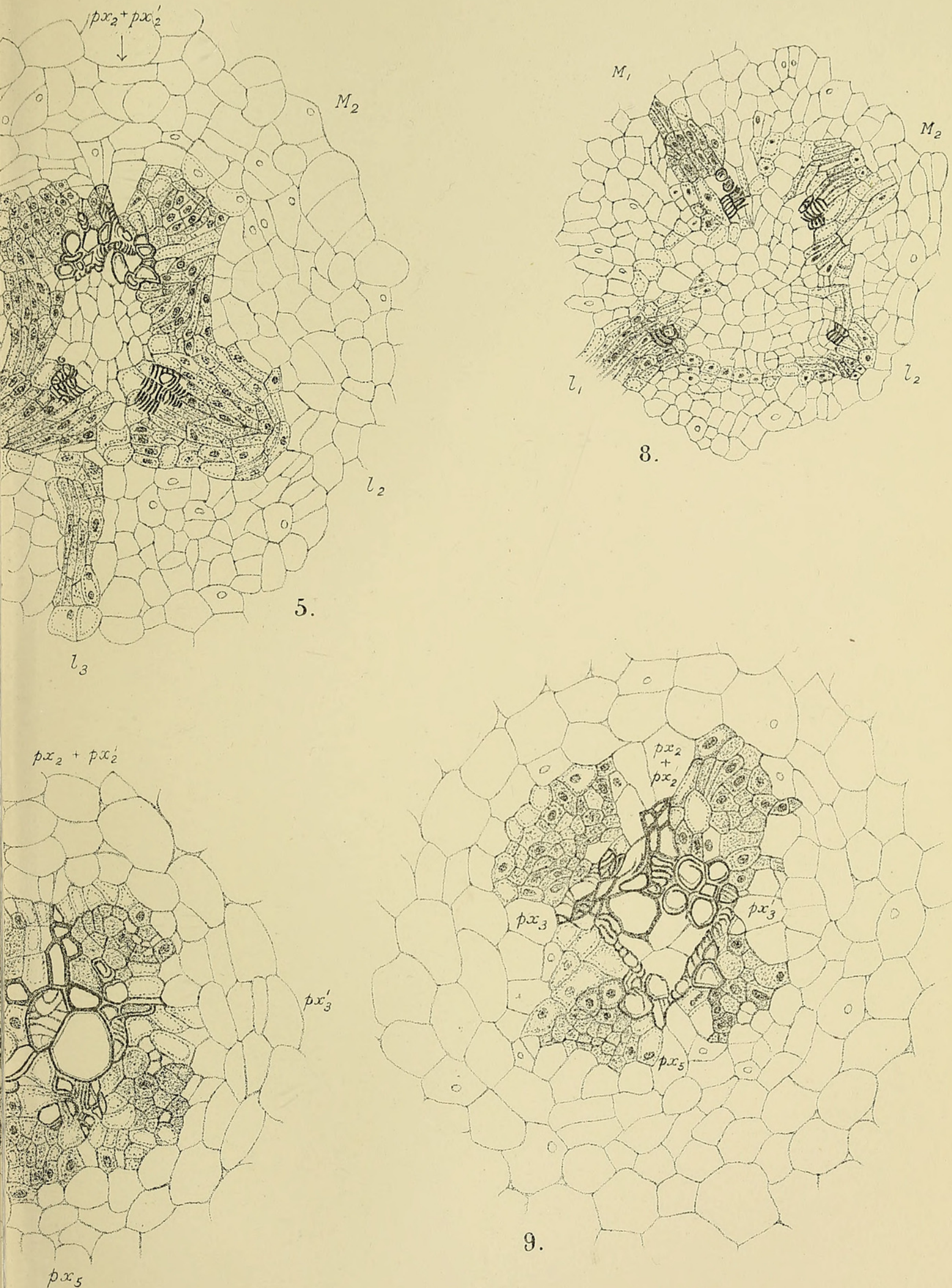

9.

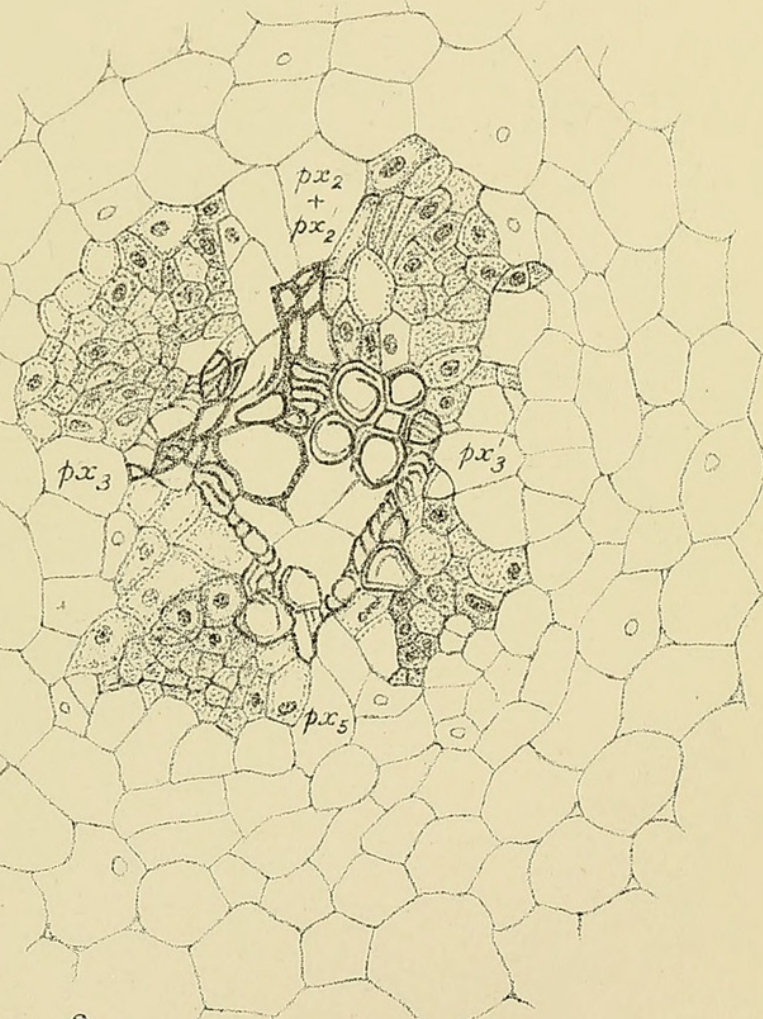



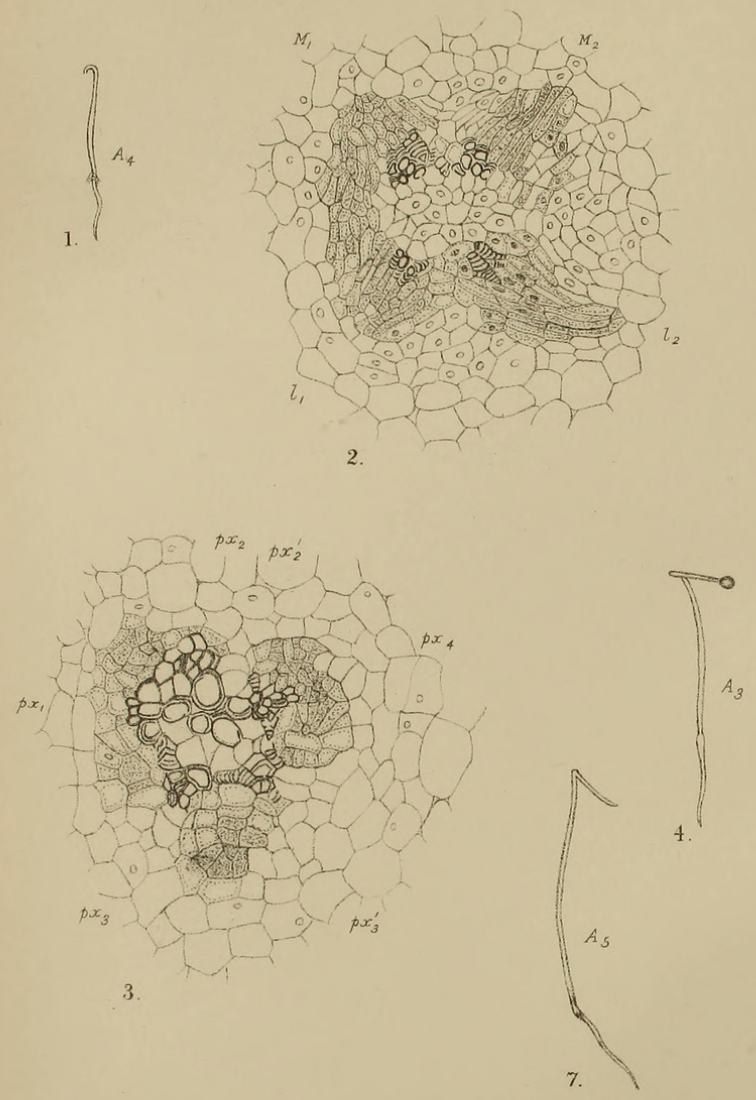

Muscari atlanticum, Figs.1-3.

Muscari armenaicum, Fiǵs. 4-9.
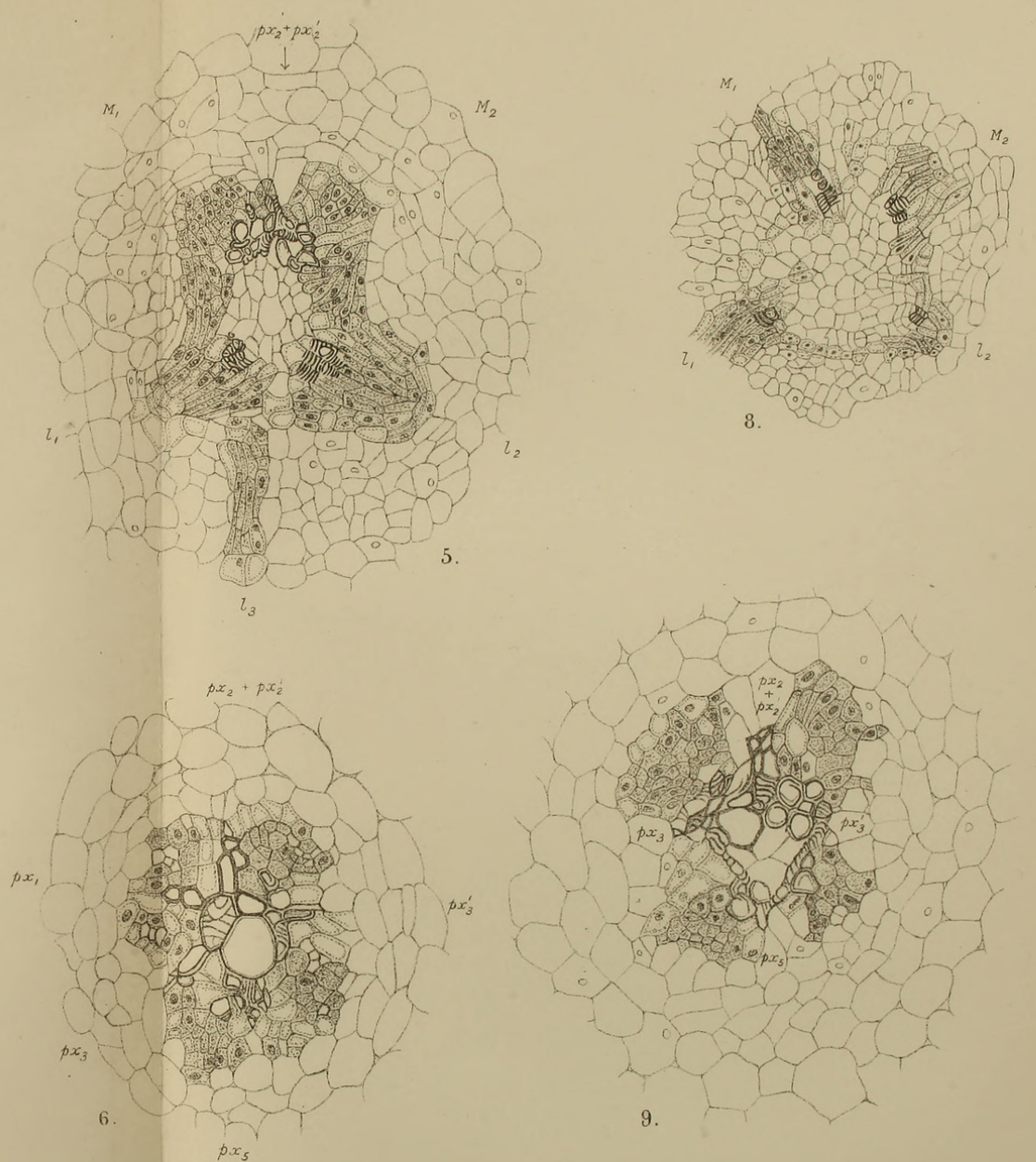

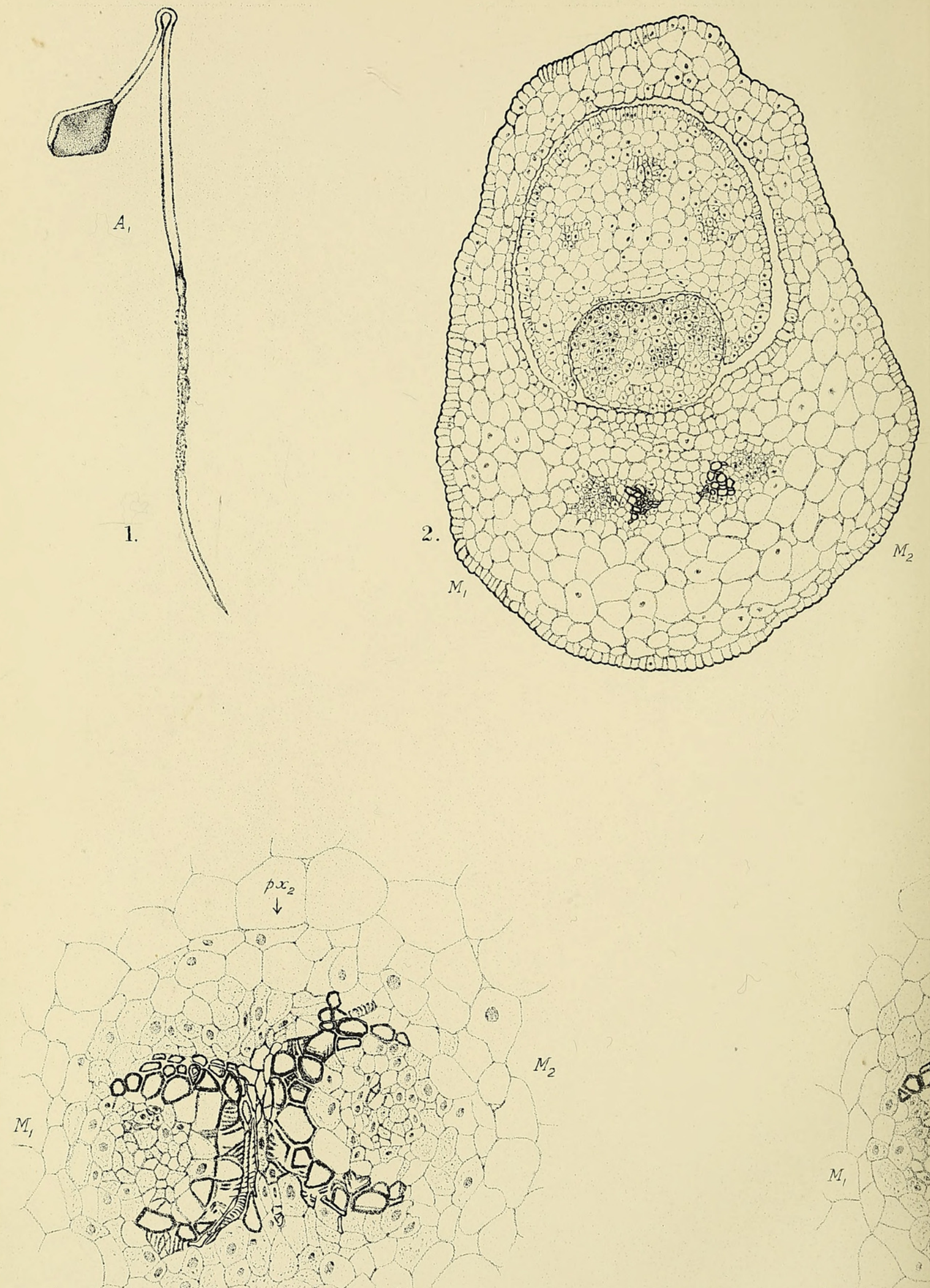

4.

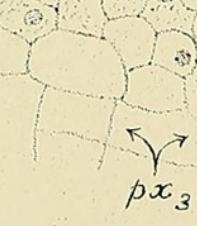

Fritillar 

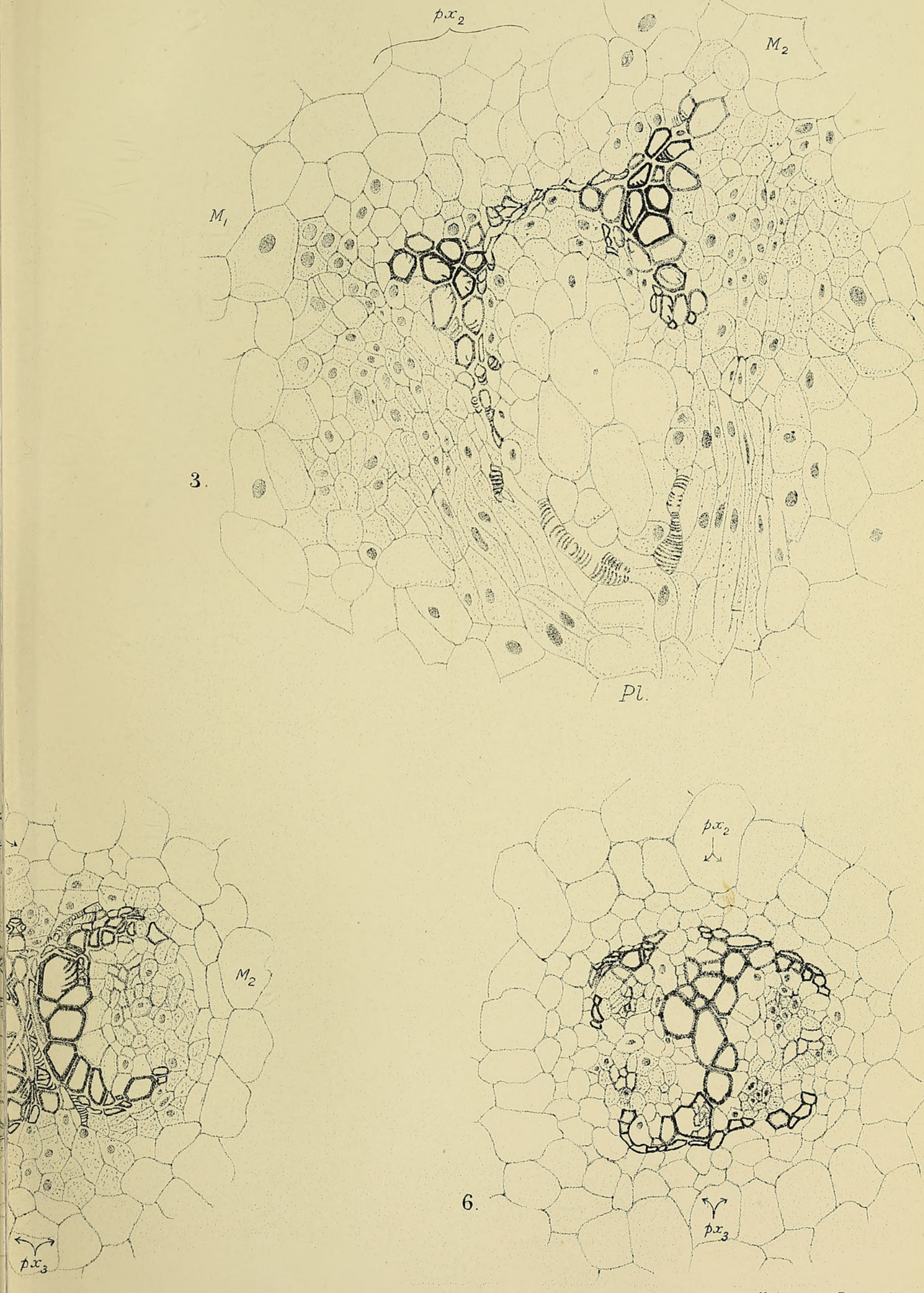

iperialis.

University Press, Oxford

F MONOCOTYLEDONS. 

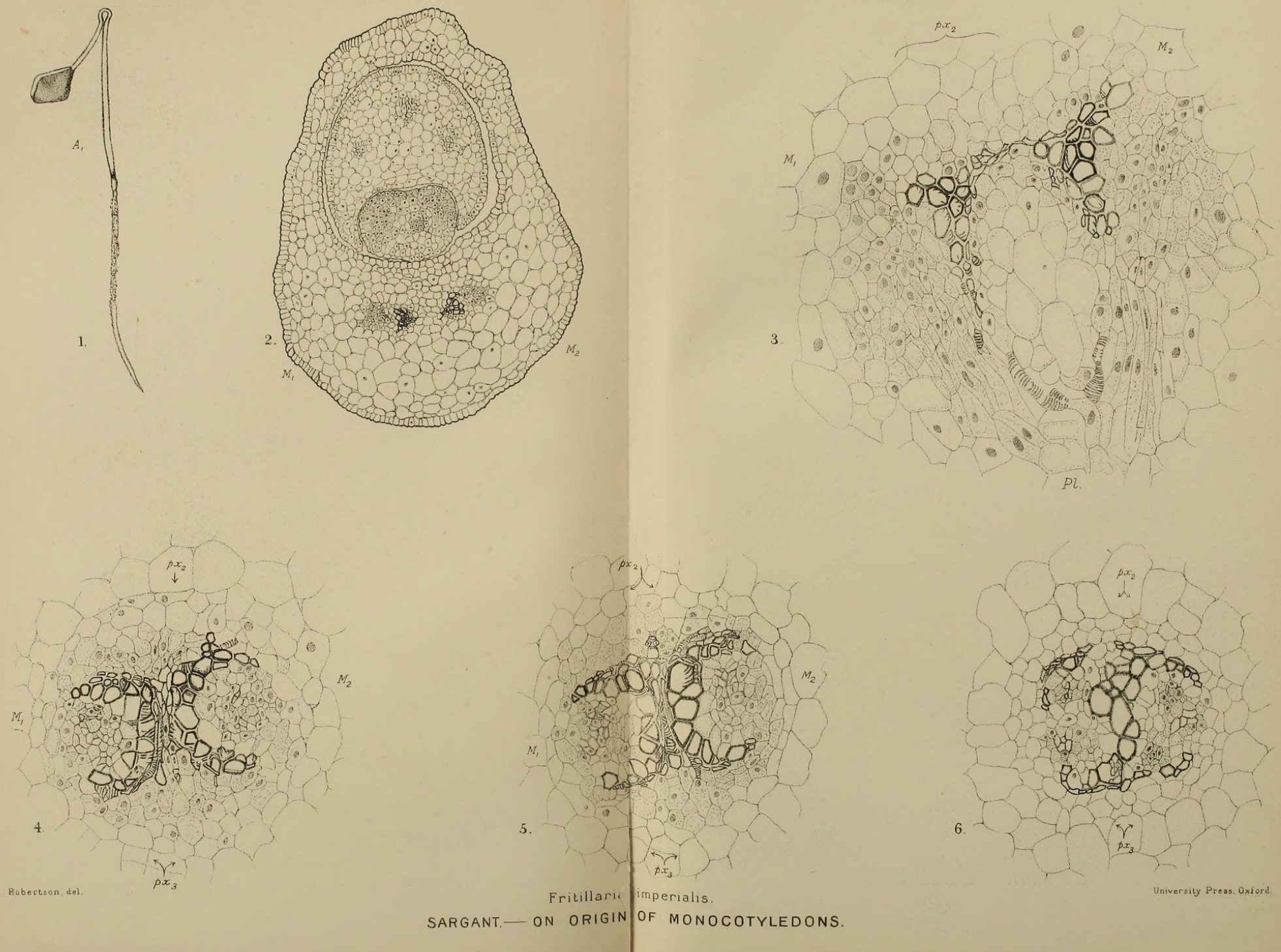


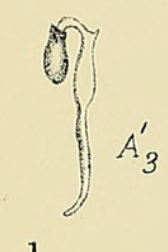

1.

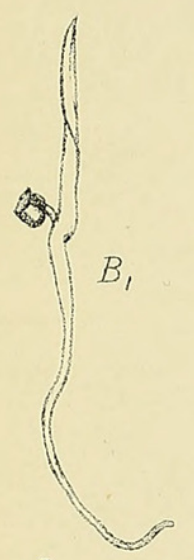

5.

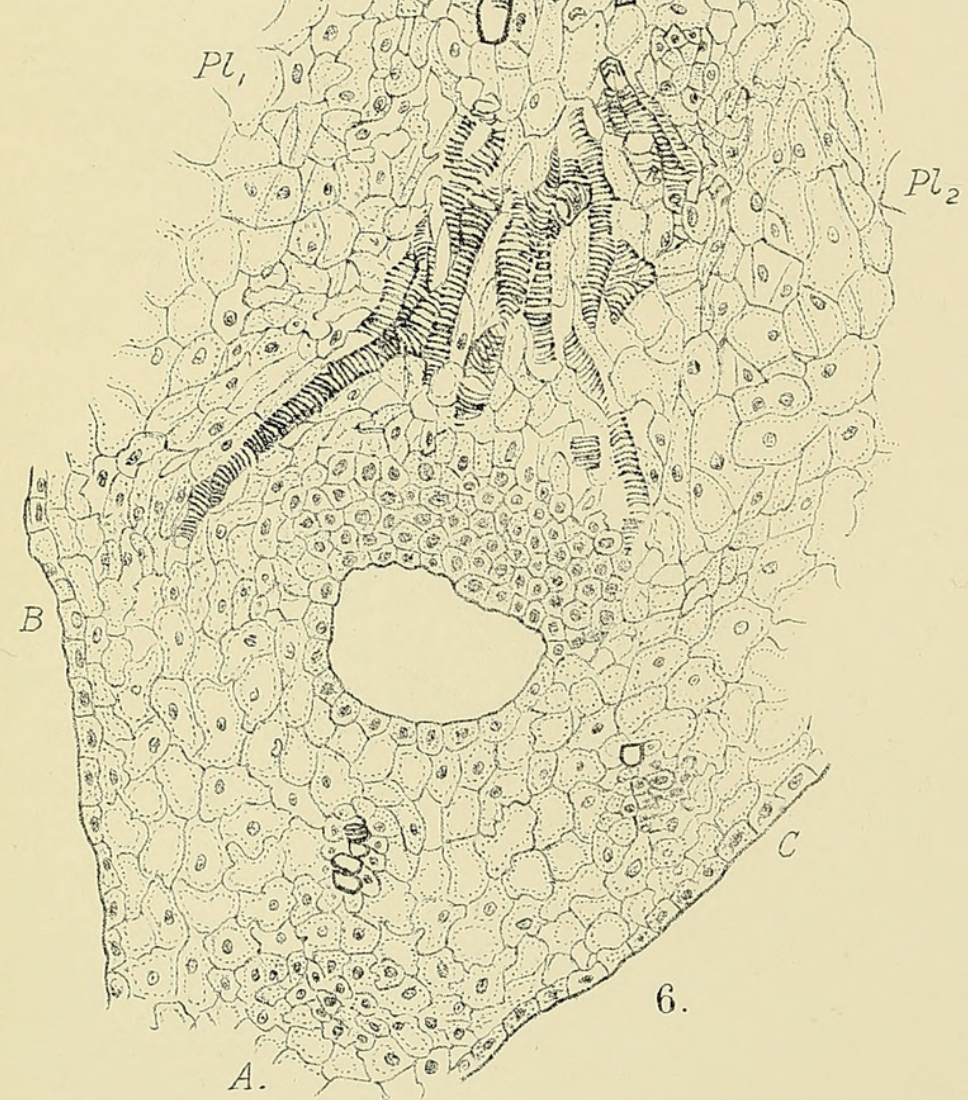

$\mathrm{Pl}_{2}$

2

$p x_{3}$ $p x$

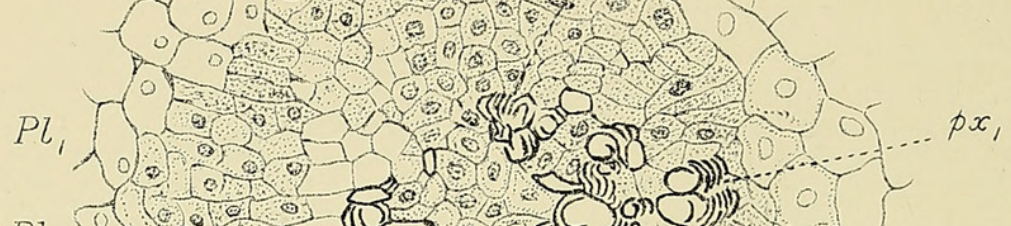

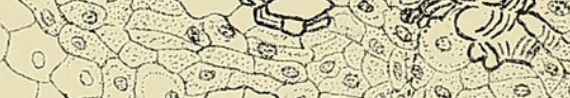

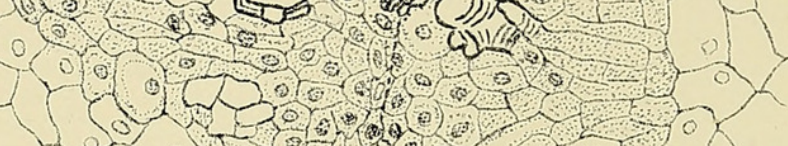

0, 0 - 20 0

. of of o o $\mathrm{M}_{2}$

3.

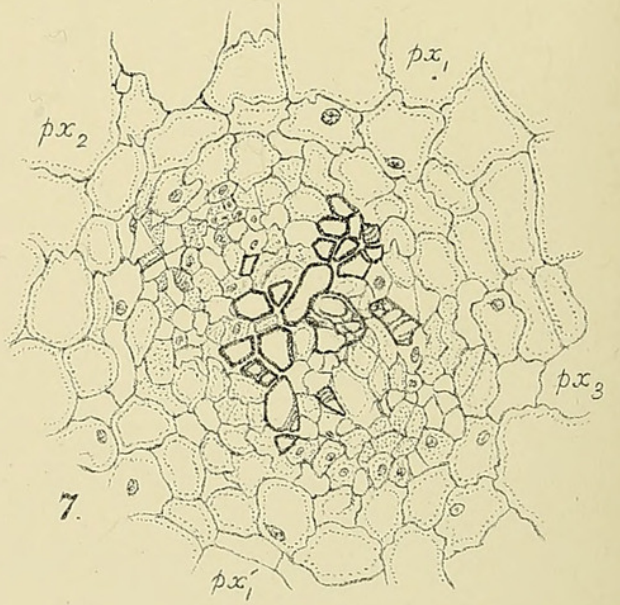

pi

Chlorogalum pomeridianum, Figs. 1-4. 

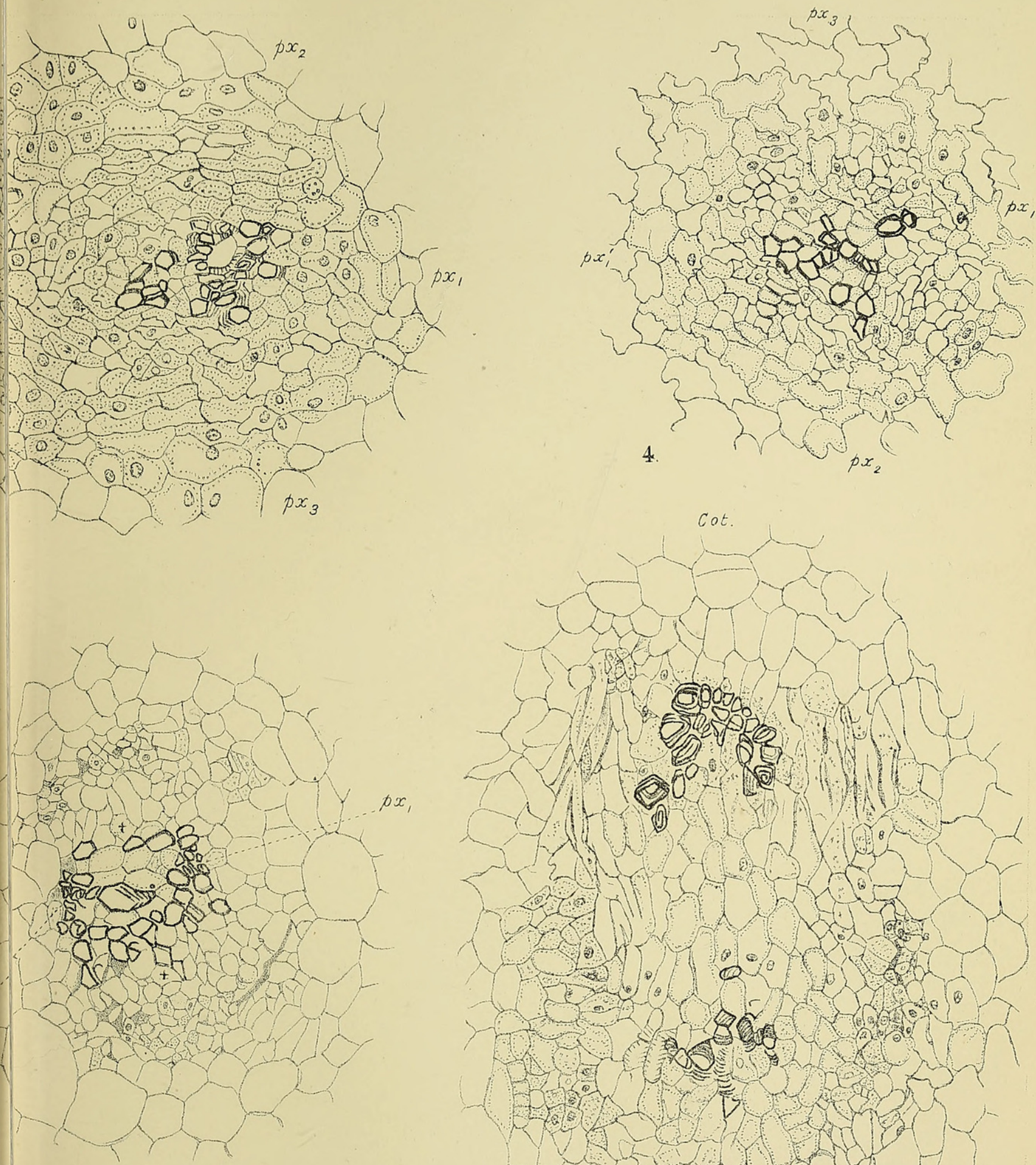

10

nthericum Liliago, Figs. 5-7.

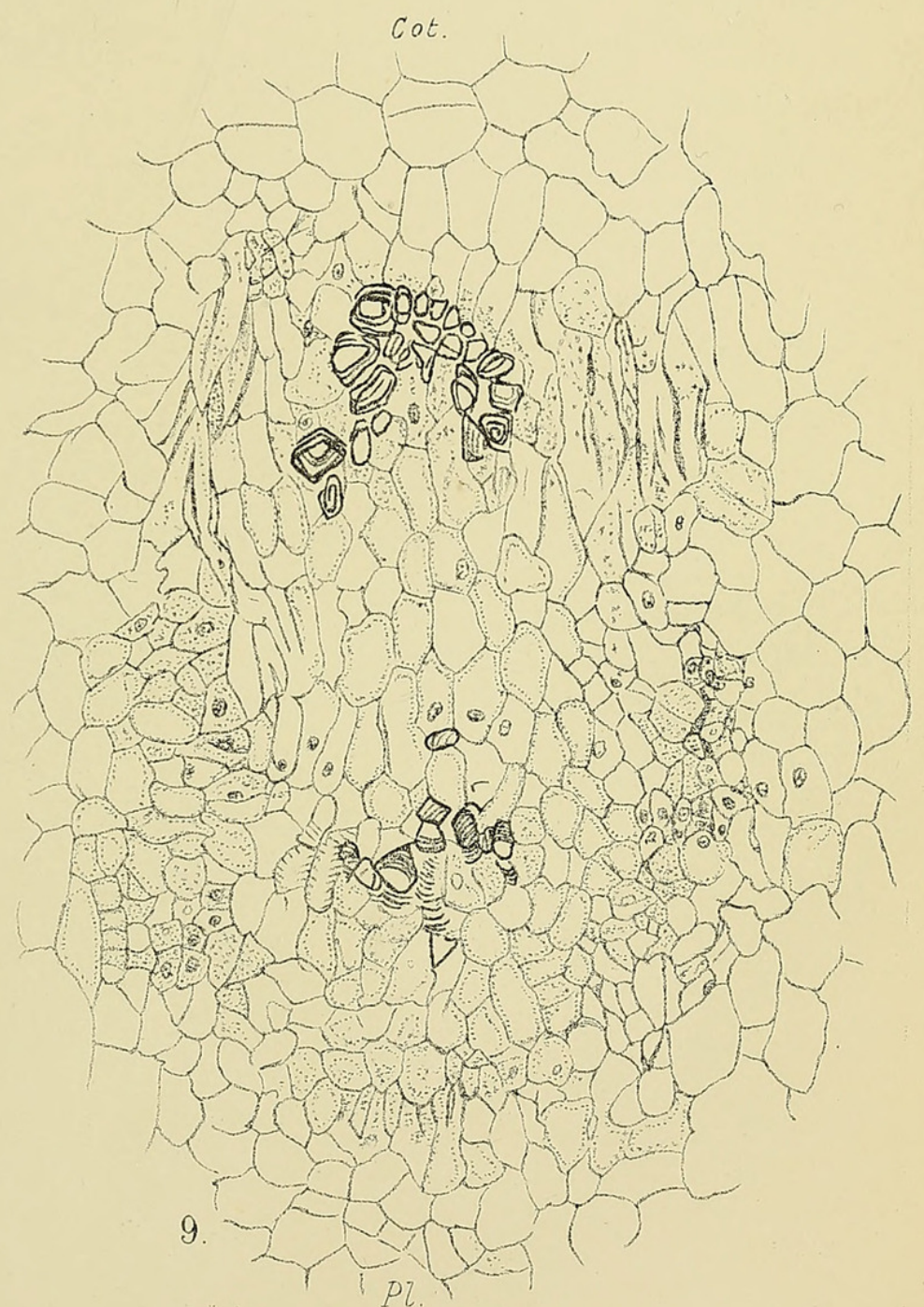

Arthropodium cirrhatum, Figs. 8-10. 


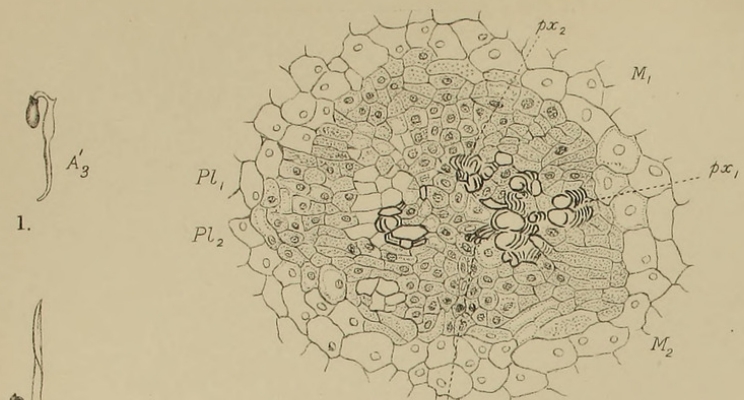

Q.

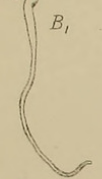

5.

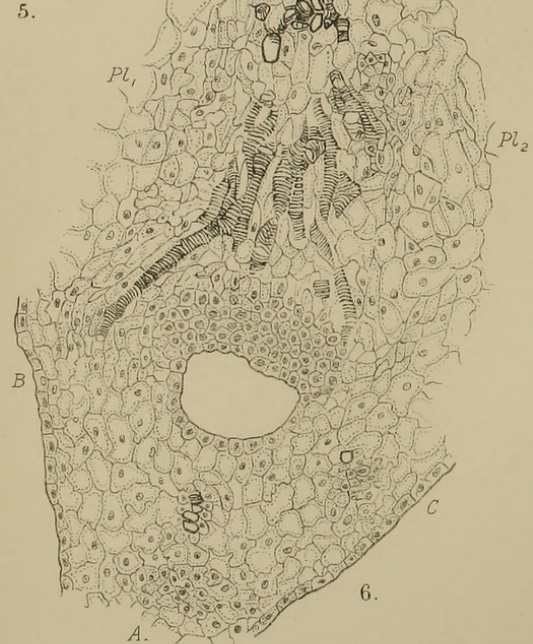

Chlorogalum pomeridianum Fiss $1=4$
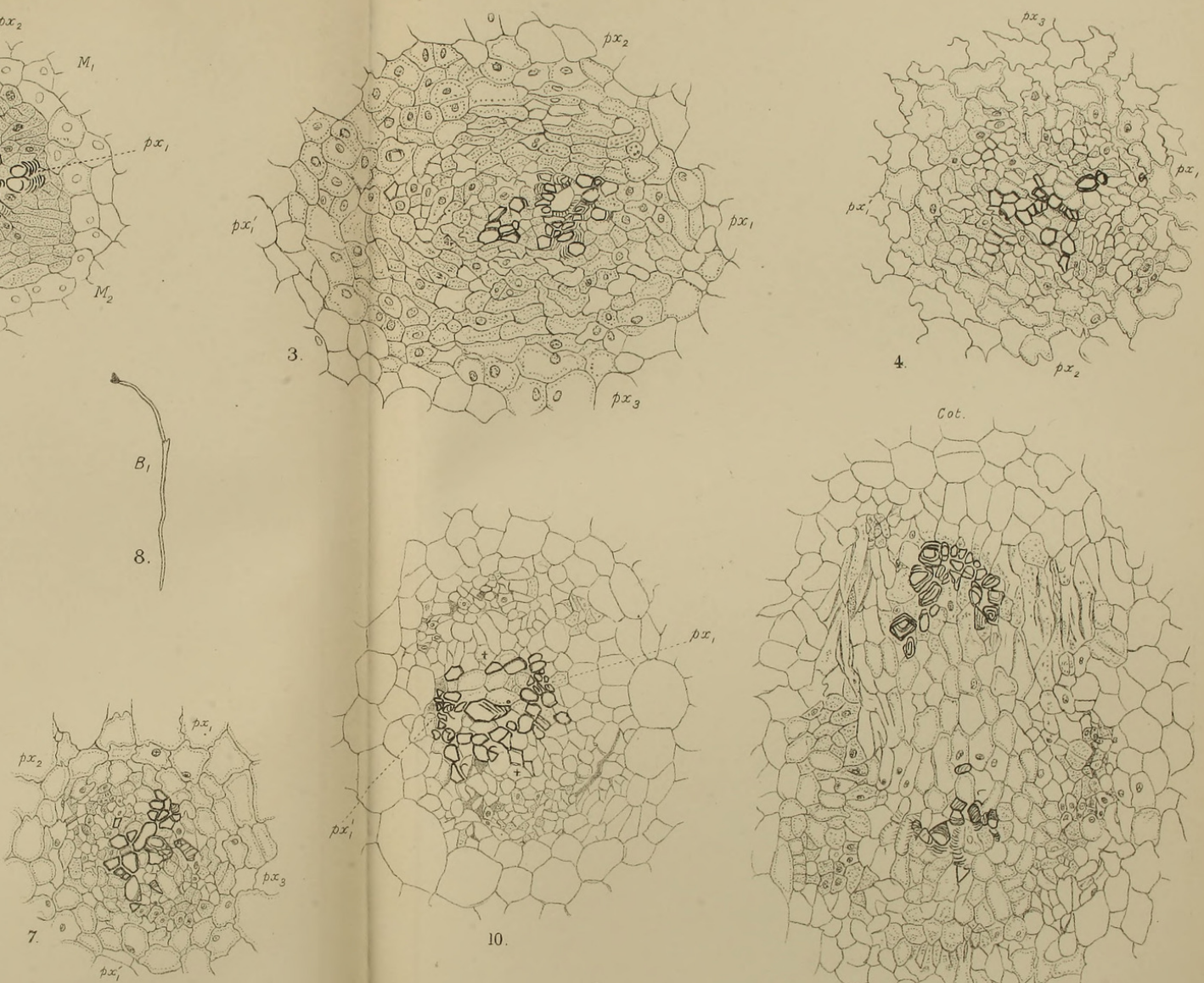

Anthericum Liliago, Figs. 5-7.

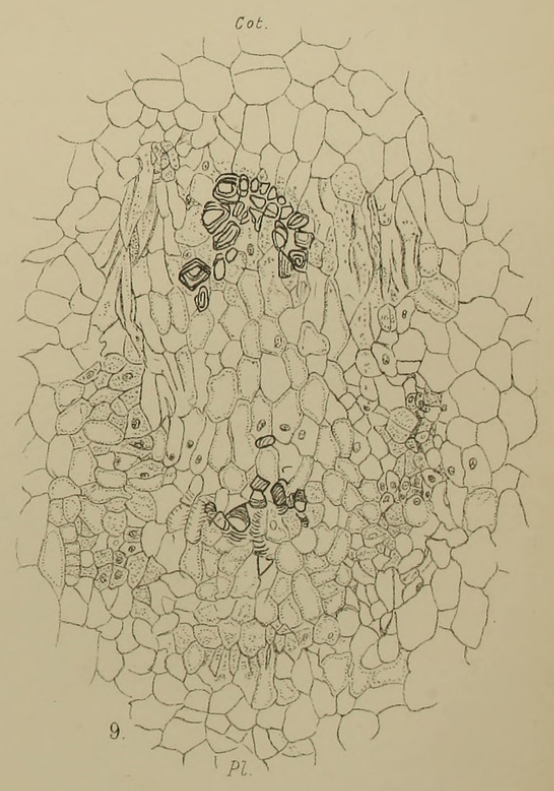

Arthropodium cirrhatum, Físs 8-10 

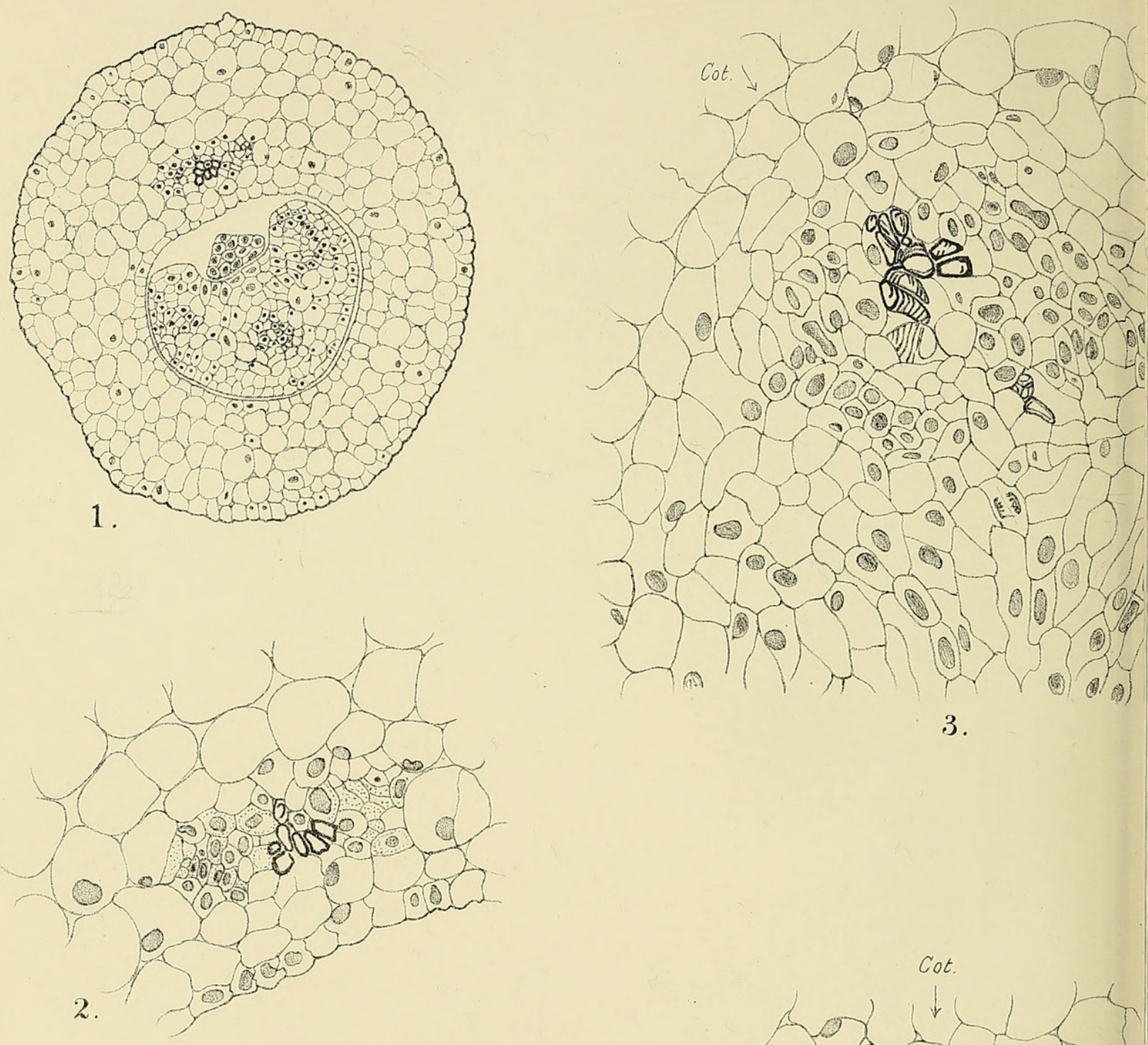

3.

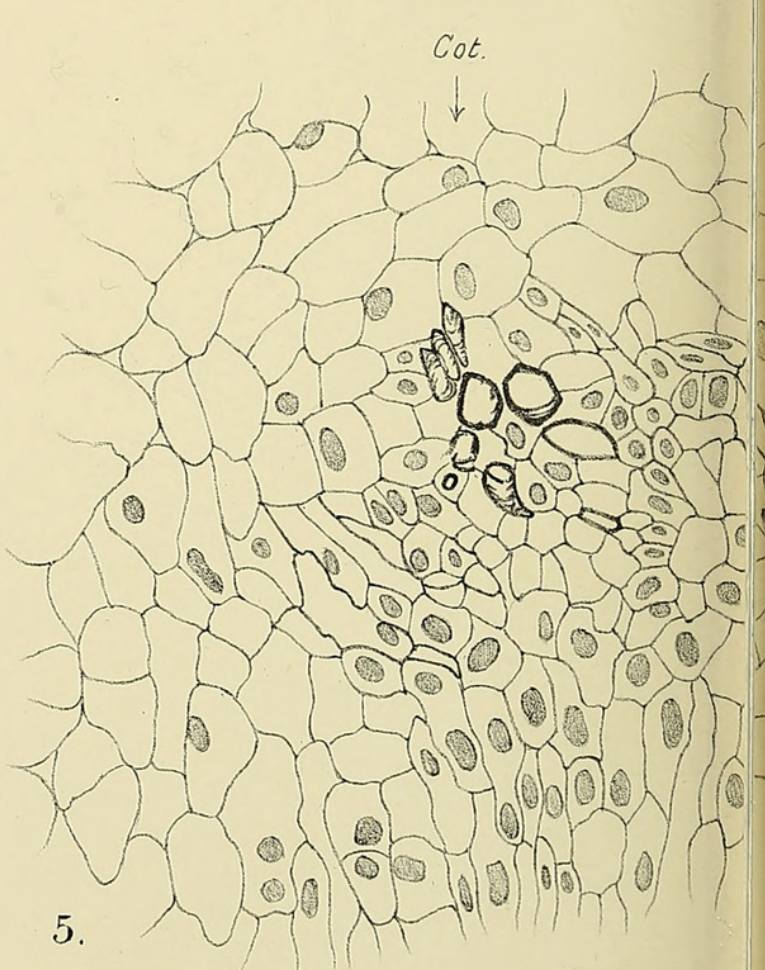

Allium neapotitanum, Figs. 1-5. 

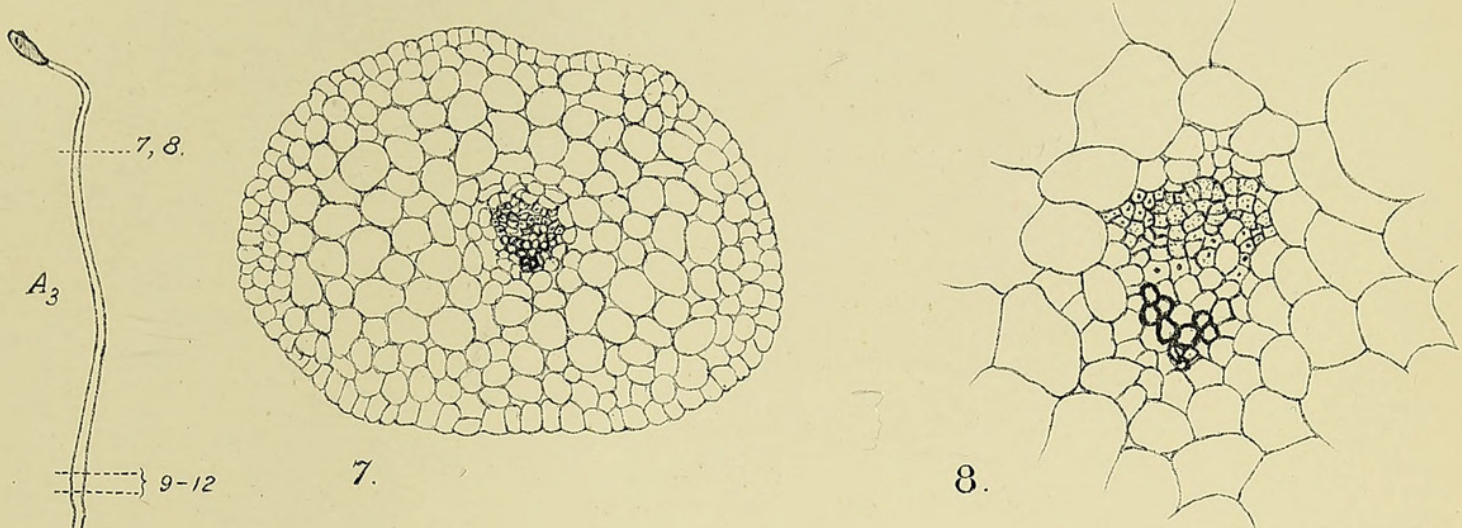

6.
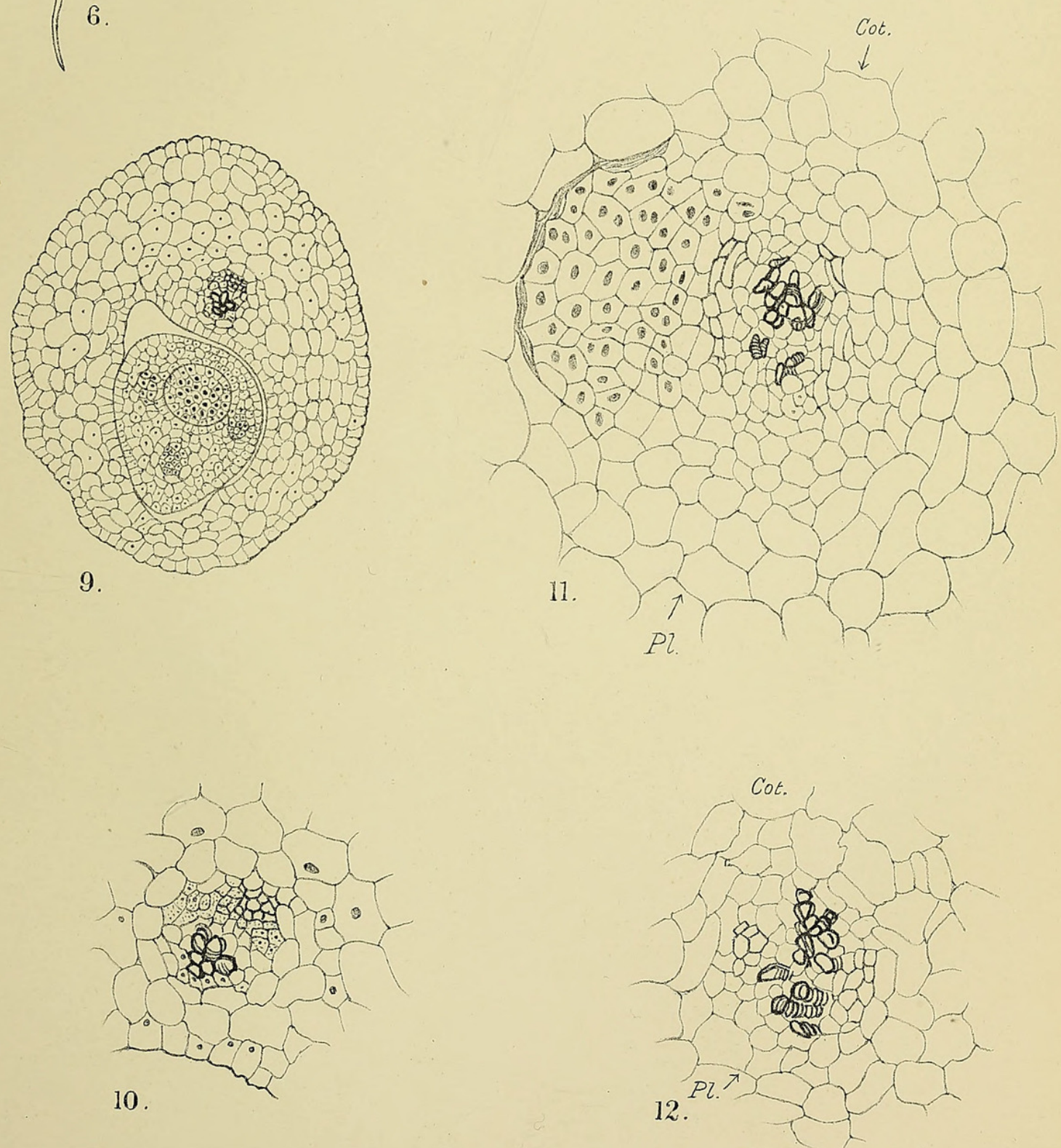

Zygadenus elegans, Figs. 6-12. 

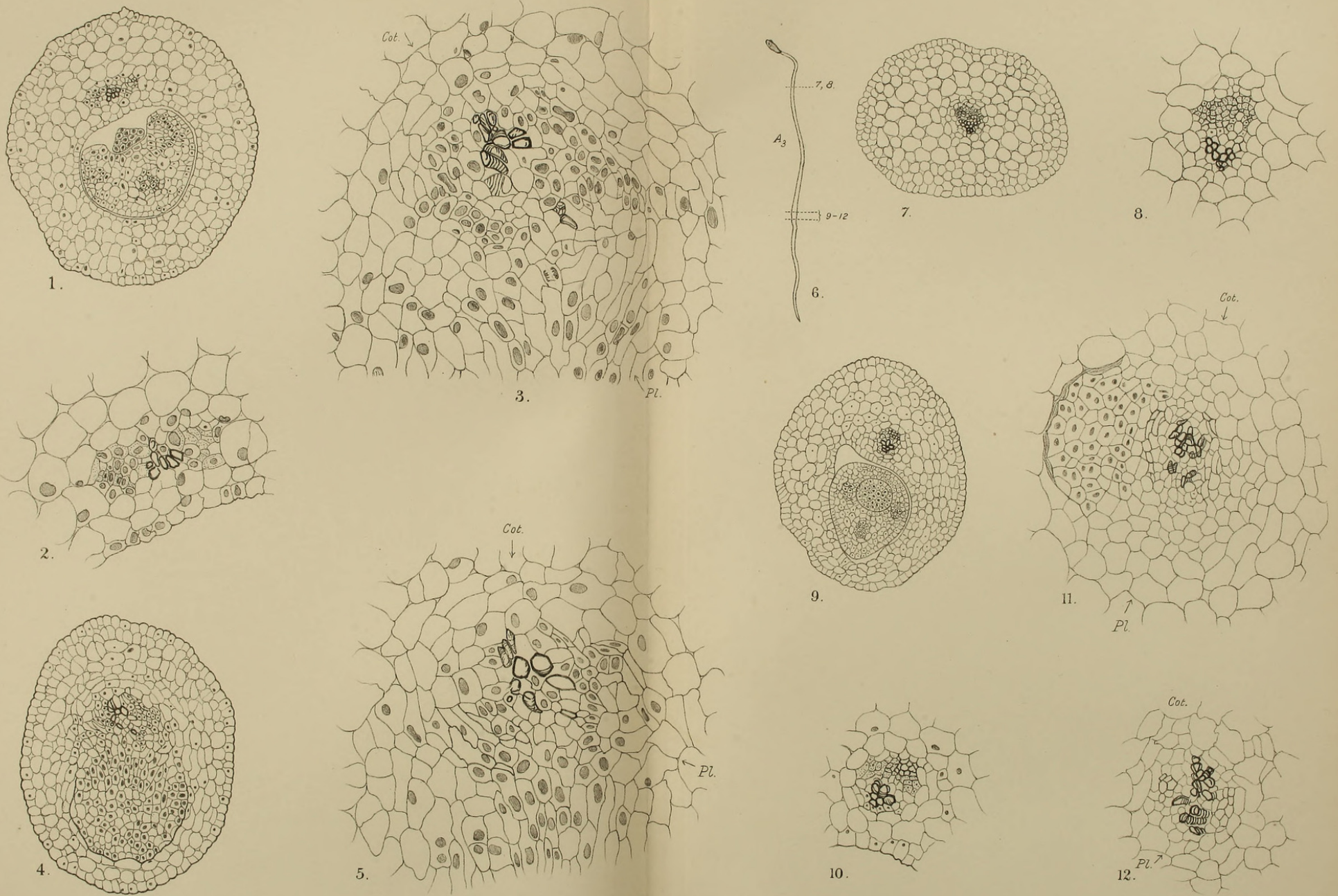

Allium neapotitanum, Fís. 1-5.
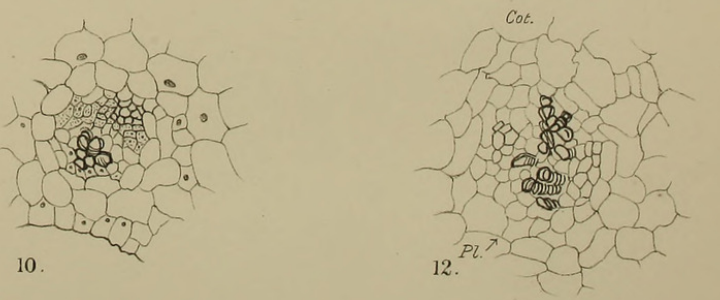

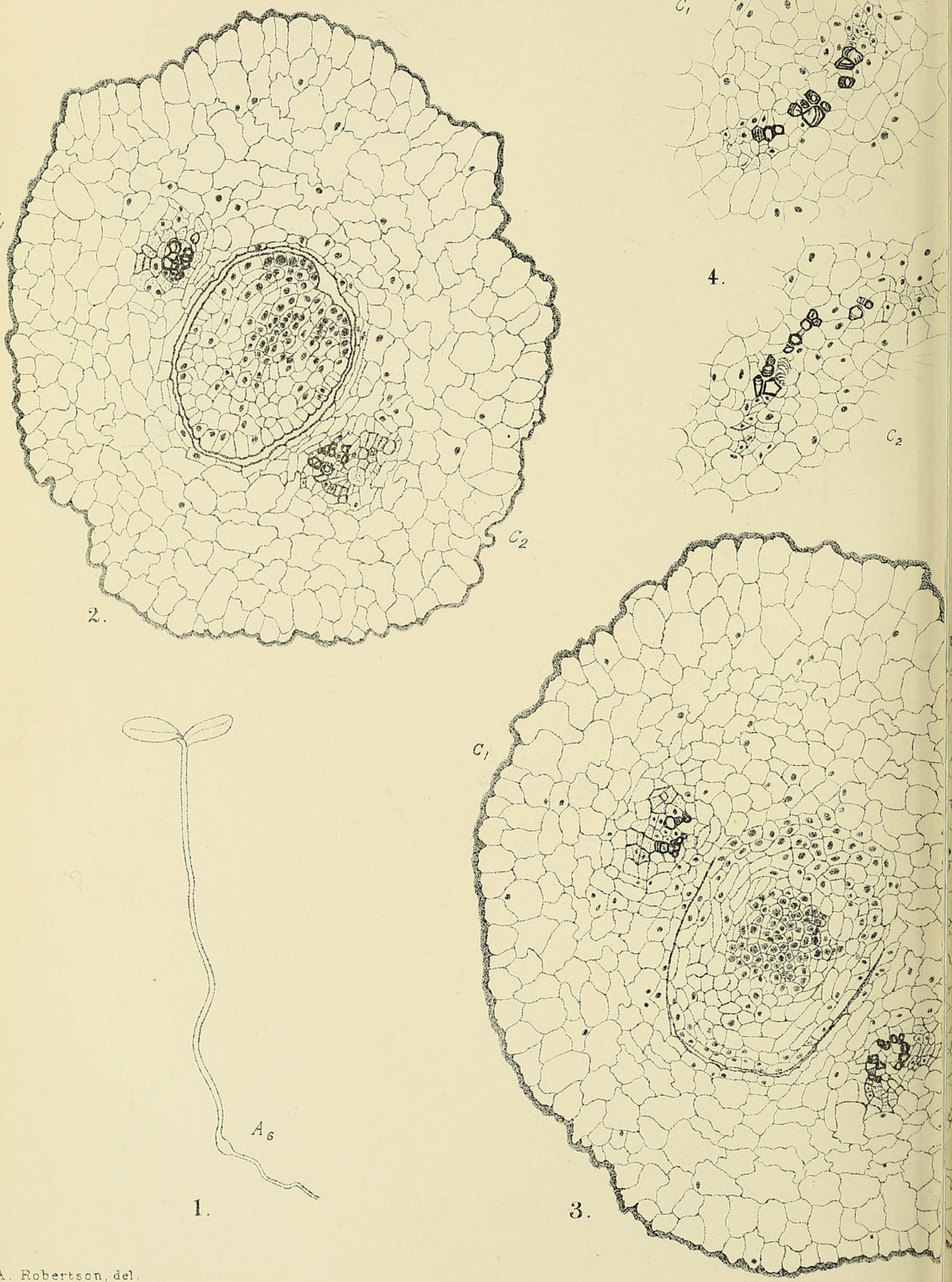

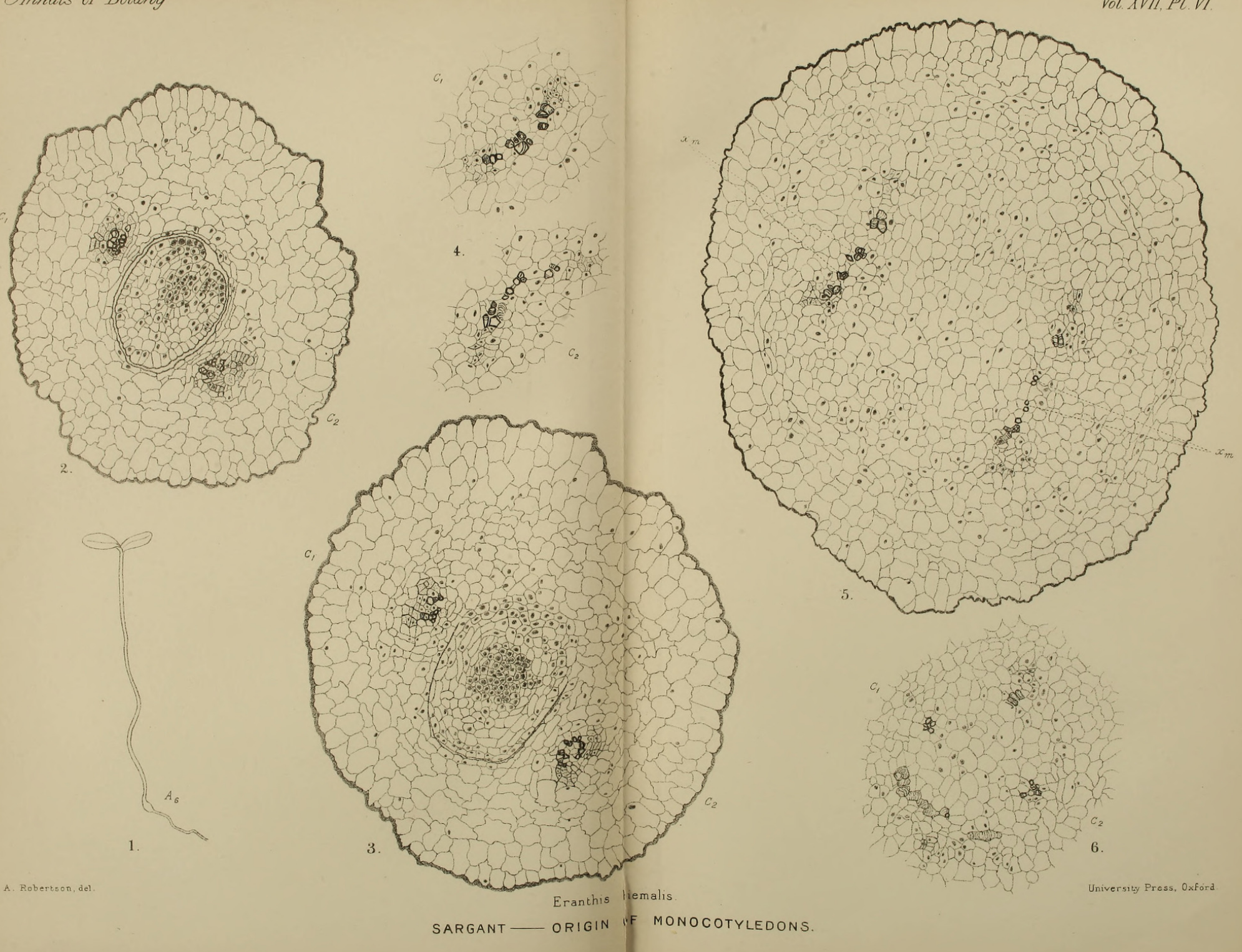

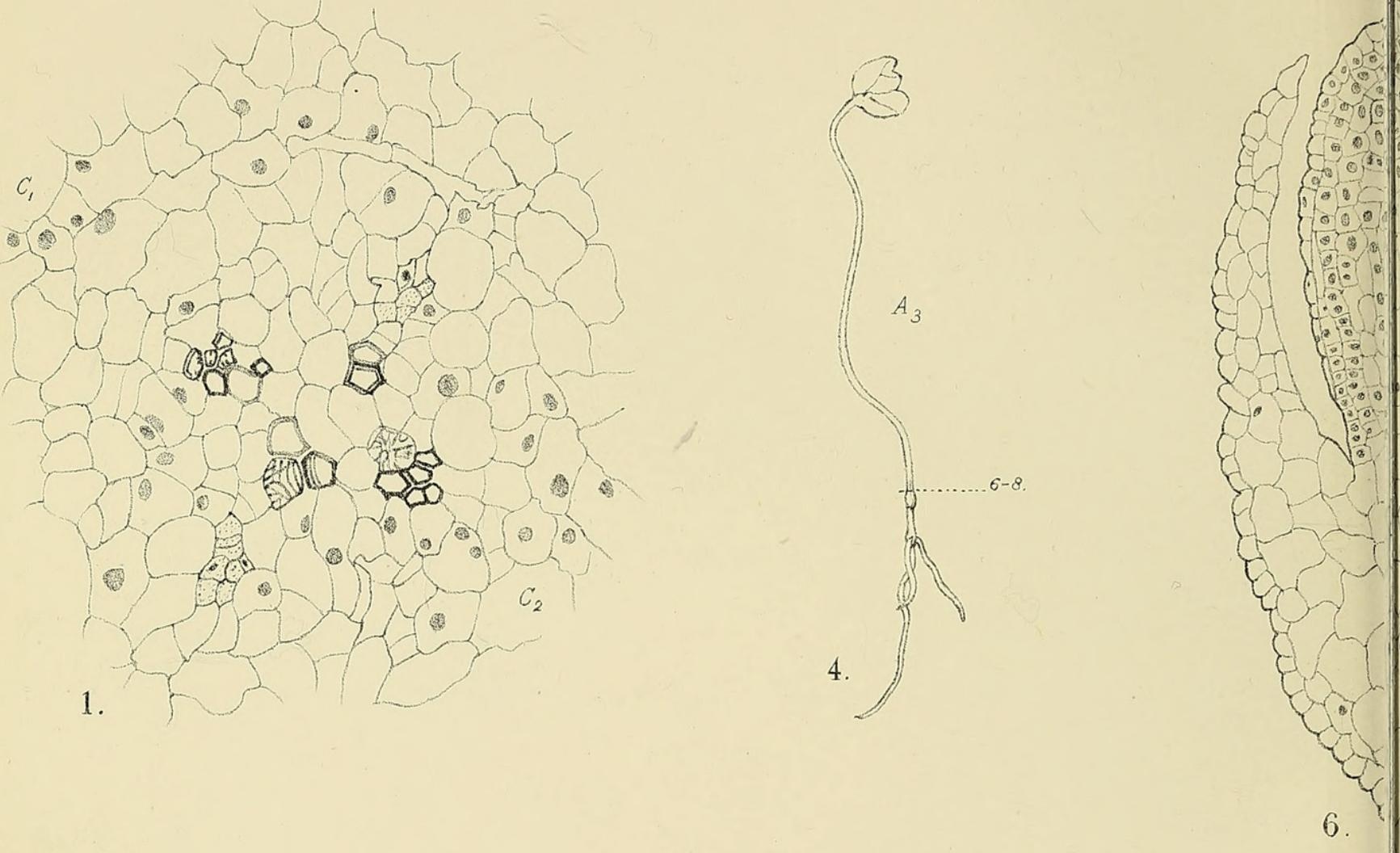

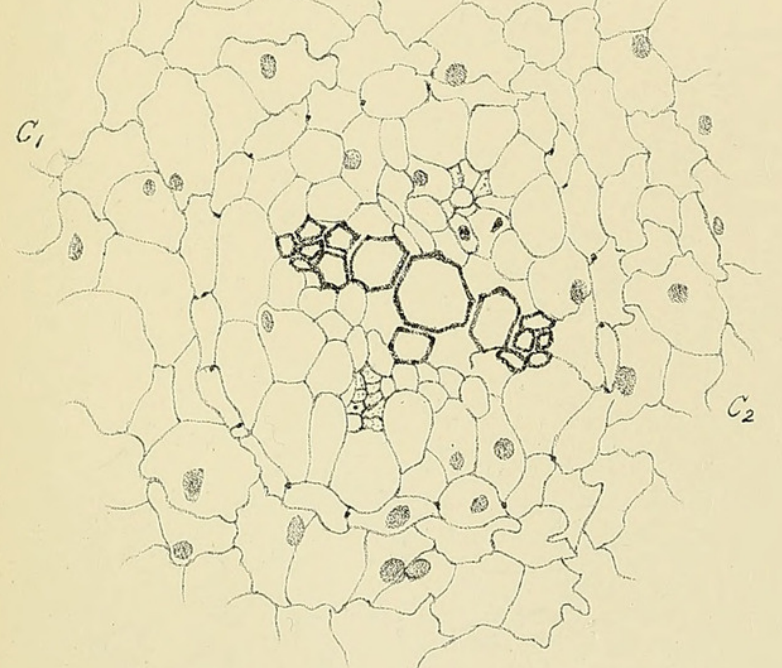

2.

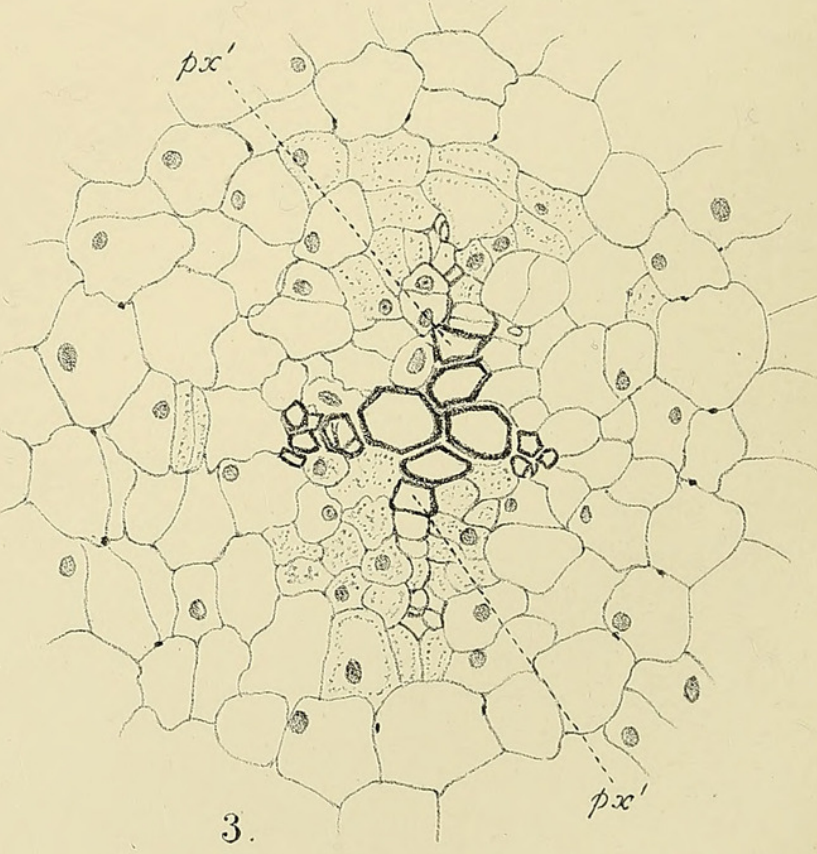

3.

Eranthis hiemalis. Figs. 1-3. 

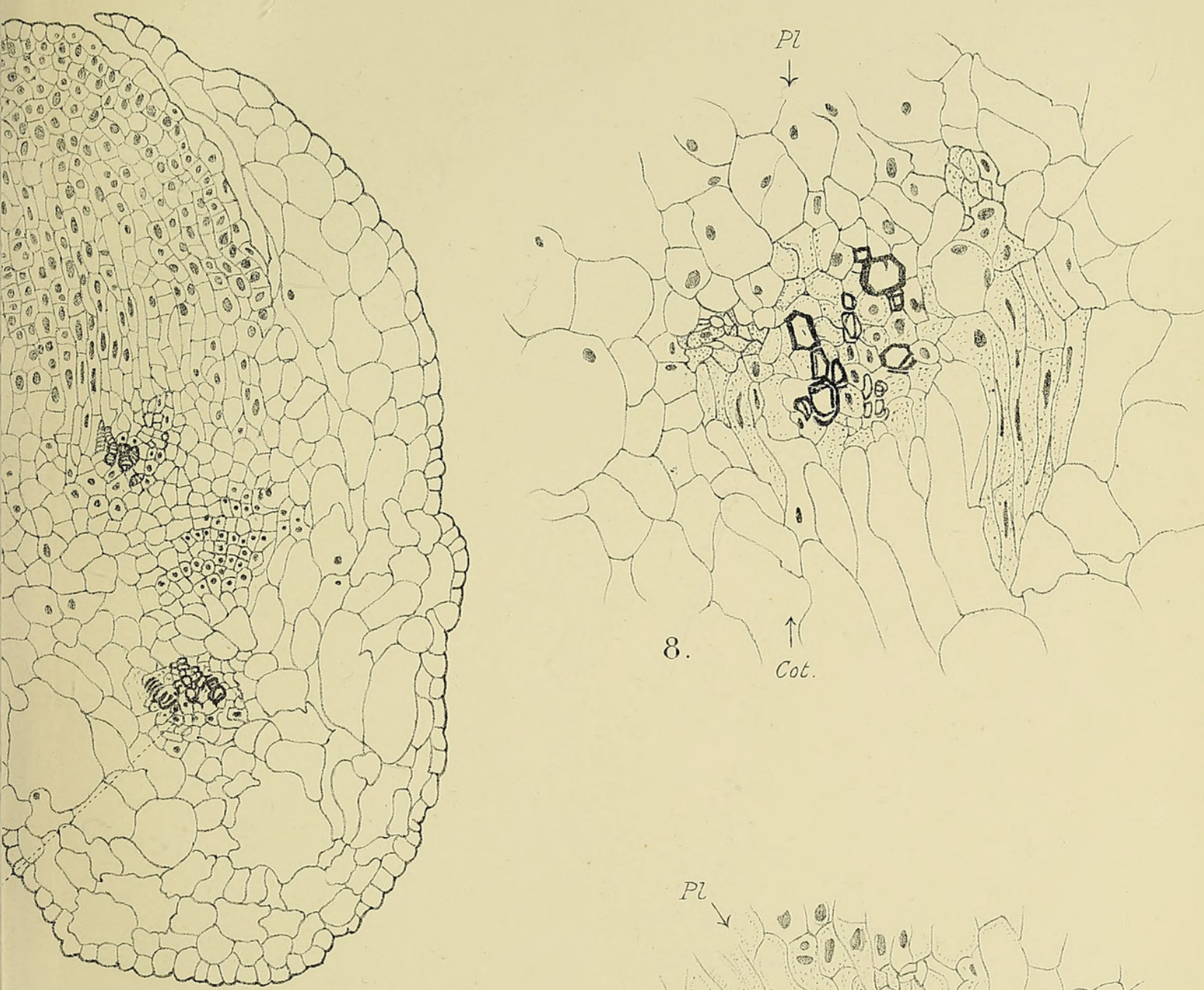

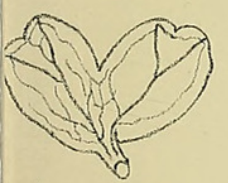

$A_{3}$

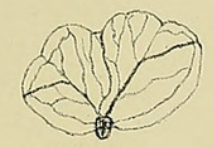

$\mathrm{A}_{4}$

5.

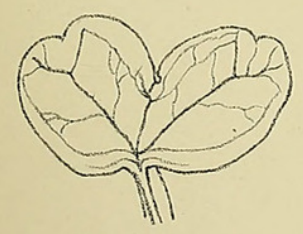

B,

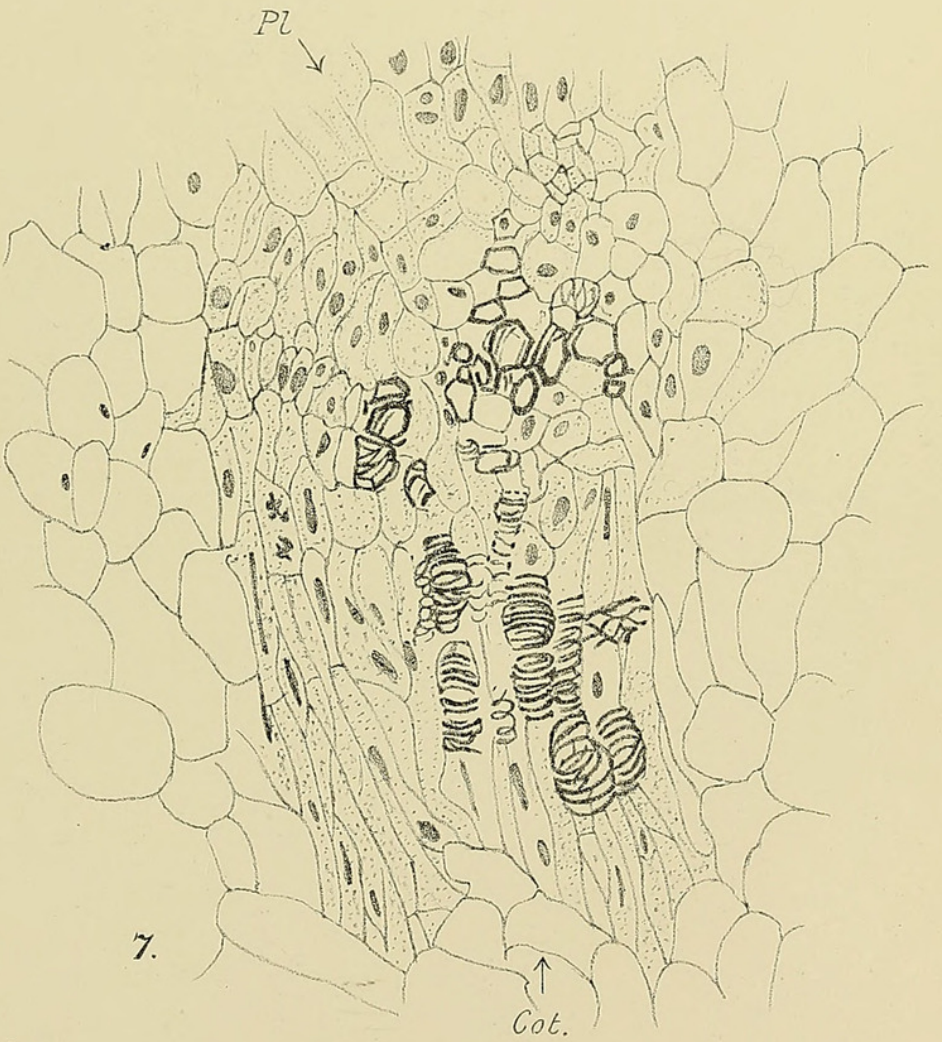

Ranunculus Ficaria, Figs 4-8. 

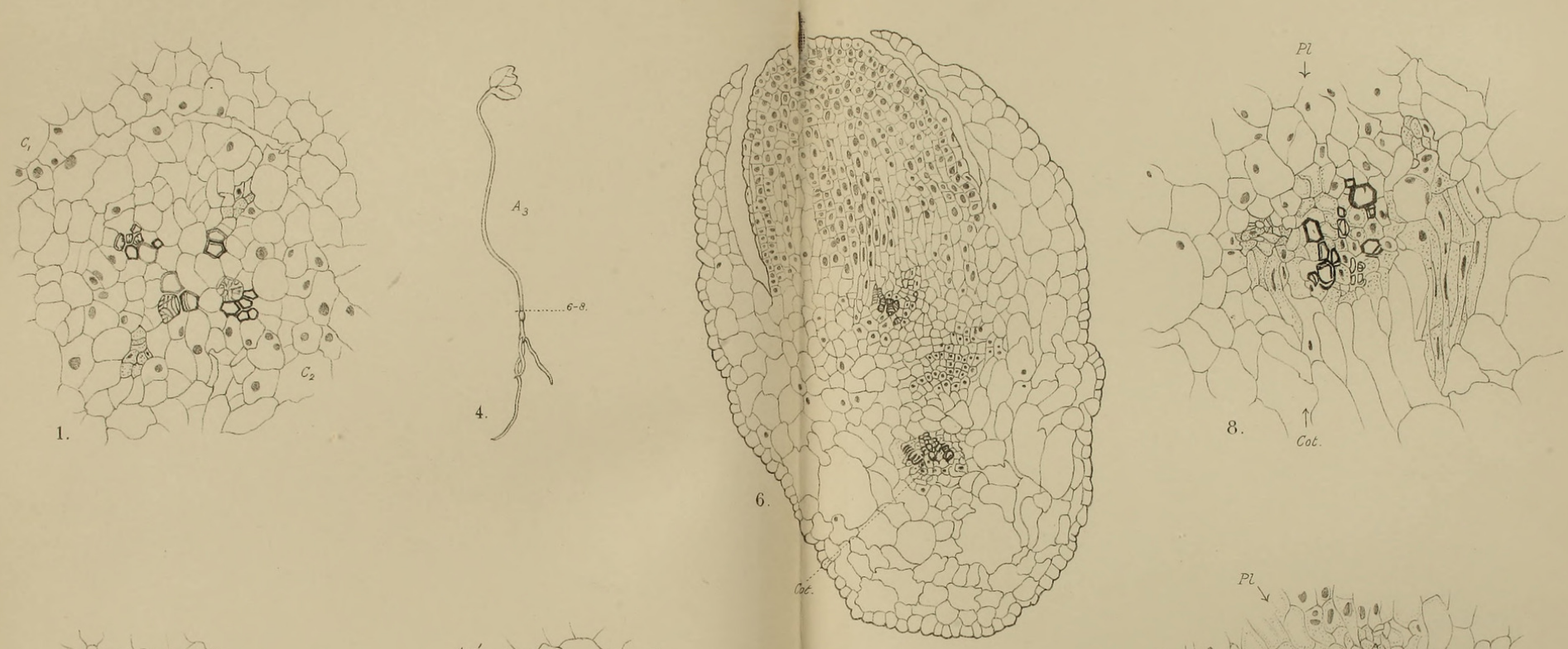

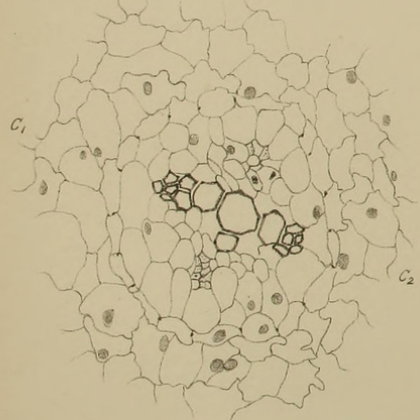

2 .

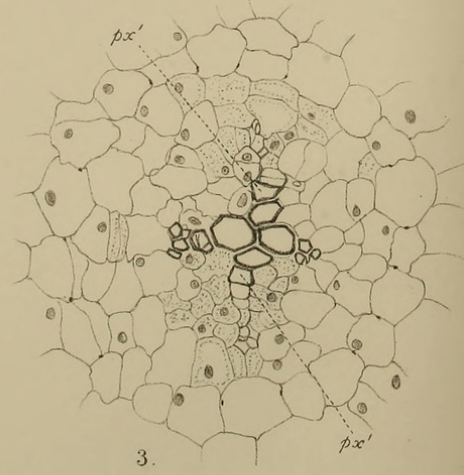

Eranthis hiemalis. Figs. 1-3

Ranunculus Ficaria, Figs 4-8 


\section{$2 \mathrm{BHL}$ Biodiversity Heritage Library}

Sargant, Ethel. 1903. "A theory of the origin of monocotyledons, founded on the structure of their seedlings." Annals of botany 17, 1-92. https://doi.org/10.1093/oxfordjournals.aob.a088906.

View This Item Online: https://www.biodiversitylibrary.org/item/235015

DOI: https://doi.org/10.1093/oxfordjournals.aob.a088906

Permalink: https://www.biodiversitylibrary.org/partpdf/318704

\section{Holding Institution}

Smithsonian Libraries

\section{Sponsored by}

Biodiversity Heritage Library

\section{Copyright \& Reuse}

Copyright Status: Not in copyright. The BHL knows of no copyright restrictions on this item.

This document was created from content at the Biodiversity Heritage Library, the world's largest open access digital library for biodiversity literature and archives. Visit BHL at https://www.biodiversitylibrary.org. 